JACINTO CARLOS ASCENCIO CANSADO

\title{
AGRILOGIC \\ SISTEMA PARA EXPERIMENTAÇÃO DE CONTROLE CLIMÁTICO DE CASAS DE VEGETAÇÃO
}

Dissertação apresentada à Escola Politécnica da Universidade de São Paulo para obtenção do Título de Mestre em Engenharia.

São Paulo 


\title{
AGRILOGIC
}

\section{SISTEMA PARA EXPERIMENTAÇÃO DE CONTROLE CLIMÁTICO DE CASAS DE VEGETAÇÃO}

\author{
Dissertação apresentada à Escola \\ Politécnica da Universidade de São Paulo \\ para obtenção do Título de Mestre em \\ Engenharia. \\ Área de Concentração: \\ Sistemas Digitais \\ Orientador: \\ Prof. Livre-Docente \\ Antonio Mauro Saraiva
}


Cansado, Jacinto Carlos Ascencio

AGRILOGIC sistema para experimentação de controle climático de casas de vegetação / Jacinto Carlos Ascencio Cansado -- São Paulo, 2003.

$118 \mathrm{p}$.

Dissertação (Mestrado ) - Escola Politécnica da Universidade de São Paulo. Departamento de Engenharia de Computação e Sistemas Digitais.

1. Estufas (Automação) 2. Agricultura (Automação) 3. Engenharia Agrícola I. Universidade de São Paulo. Escola Politécnica. Departamento de Engenharia de Computação e Sistemas Digitais II.t 
Dedico este trabalho a minha família. A minha esposa Margarete, as minhas filhas Beatriz e Júlia e especialmente a minha mãe Mara que recentemente juntou-se a Deus. Elas são as razões da minha busca pelo meu desenvolvimento, empenho, dedicação e perseverança. 


\section{AGRADECIMENTOS}

Agradeço a Deus, por me dar consciência, saúde e paz.

Ao meu orientador, o Prof. Dr. Antonio Mauro Saraiva, pela paciência e constantes incentivos que me motivaram a realizar o presente trabalho.

Aos amigos do Departamento de Ecologia do Instituto de Biociências da USP, Marico Meguro, Vera Lucia Imperatriz Fonseca e Sérgio Tadeu Meirelles, que através do envolvimento e colaboração propiciaram a realização deste trabalho.

Aos colegas e amigos do LAA Alerso, Alexandre, Antonio, Augusto, Cristian, Danilo, Etienne, Fábio, Graziela, José Maurício, Luiz Carlos, Madeleine, Marcelo, Marcio e Renato.

À Elisabeth Adriana Dudziak e ao Sérgio Miranda Paz pela gentileza de realizarem a leitura, as correções e as sugestões do texto de minha dissertação. 


\section{RESUMO}

A agricultura tradicional realizada em campo aberto é dependente do meio físico natural, sendo sua prosperidade resultado de circunstâncias favoráveis do solo, do clima e água, entre outros. A necessidade crescente de se produzir vegetais com alta qualidade, do planejamento da produção agrícola em termos de quantidade e prazo, da redução dos custos por unidade de produção, com a manutenção ou aumento da qualidade têm levado a um aumento da utilização de cultivo protegido. A realização da produção agrícola com uma certa independência das condições climáticas pode ser obtida através da utilização de casas de vegetação, comercialmente conhecidas como estufas. Diversos estudos mostram que as principais variáveis climáticas envolvidas no processo de produção vegetal são: a temperatura, a umidade, a luminosidade e a concentração de gás carbônico. A presença desses fatores, dentro de certos limites mínimos e máximos, proporciona condições propícias para o desenvolvimento vegetal, enquanto que fora desses limites, o desenvolvimento é prejudicado. Portanto, uma boa política de controle dessas variáveis torna-se imprescindível. Este trabalho apresenta um sistema desenvolvido para a pesquisa em controle climático em casas de vegetação, denominado Agrilogic. Ele utiliza elementos comumente encontrados em automação industrial, como CLP (Controlador Lógico Programável) para as atividades consideradas de curto prazo e um software supervisório do tipo SCADA (Supervisory Control And Data Acquisition) para controlar as atividades consideradas de longo prazo e para a IHM (Interface Homem Máquina) de mais alto nível, num computador pessoal. A interligação do CLP com o computador pessoal é feita via modem através de uma linha telefônica. O sistema foi instalado em uma casa de vegetação do Instituto de Biociências da USP para monitoração e controle da temperatura, da umidade relativa do ar e do fotoperíodo, enquanto o computador de supervisão está localizado no Laboratório de Automação Agrícola, na Escola Politécnica da USP. 


\begin{abstract}
Traditional open field agriculture is dependent on the natural environment, and its profit is a result of/ derives from favorable soil, weather and water conditions, among other factors. The increasing need to produce high quality crops, to plan agricultural production in terms of quantity and time, to decrease costs, while maintaining or increasing quality has led to protected agriculture. Agricultural production with some independence of weather conditions can be obtained using greenhouses, which provide good weather protection for the crop. There are many studies showing that the main variables related to crop production are: air temperature, air humidity, solar radiation and carbon dioxide concentration. The maintenance of these variables between a minimum and a maximum limit provides good conditions for crop development, whereas, beyond these limits, the development is restrained. Consequently, a good control policy for these variables is deemed necessary. This work presents Agrilogic, a system for research on greenhouse climate control. It uses industrial automation devices, such as PLC (Programmable Logic Controller), which accounts for short time activities and SCADA (Supervisory Control And Data Acquisition), software responsible for the MMI (Man Machine Interface), which accounts for the long-term activities. The system was installed in a greenhouse at Instituto de Biociências, Universidade de São Paulo for temperature, air relative humidity and photoperiod monitoring and control, and it is linked to a personal computer located at the Agricultural Automation Laboratory, at Escola Politécnica da USP, via a modem and a telephone line.
\end{abstract}




\section{SUMÁRIO}

LISTA DE FIGURAS

LISTA DE TABELAS

LISTA DE ABREVIATURAS E SIGLAS

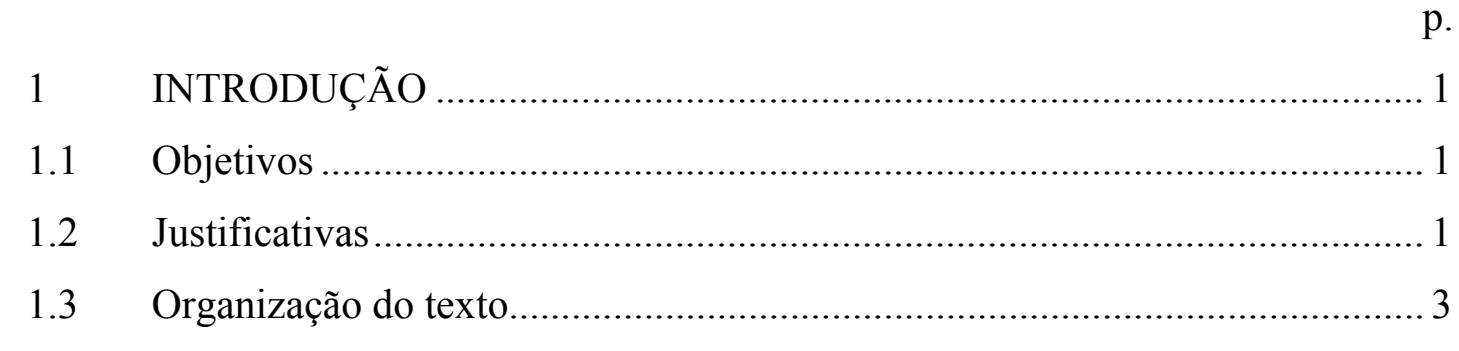

2 CULTIVO EM AMBIENTE PROTEGIDO E CONTROLADO .................... 4

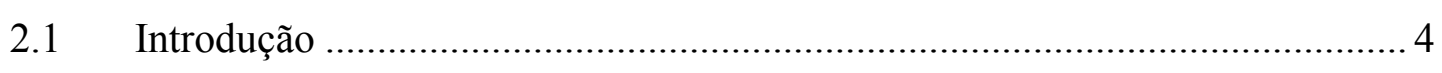

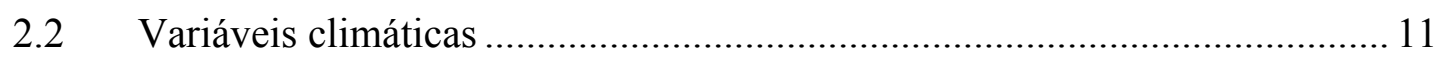

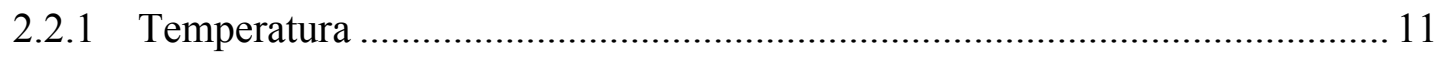

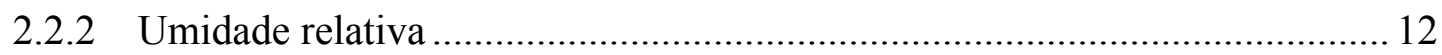

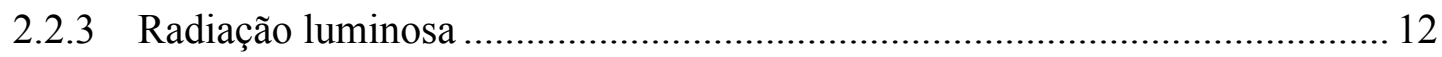

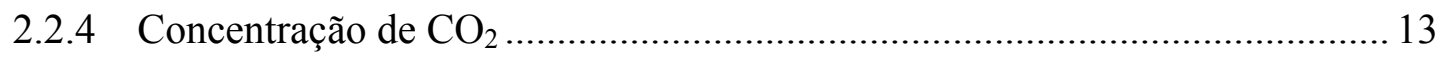

3 SISTEMAS DE CONTROLE CLIMÁTICO DE CASAS DE

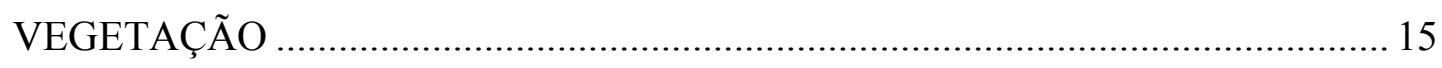

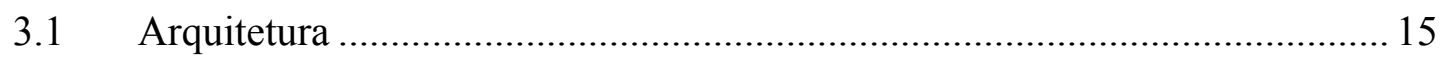

3.1.1 Sistemas de controle centralizados e distribuídos ...................................... 17

3.2 Sistemas comerciais de controle ambiental para casas de vegetação ............ 20

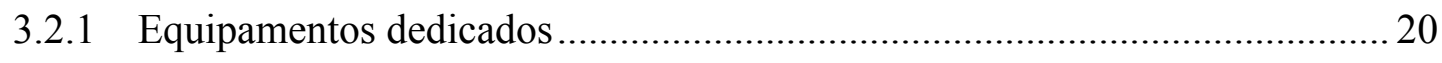

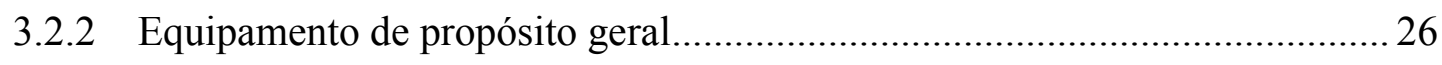

3.2.3 Algumas considerações sobre o mercado nacional ...................................... 28

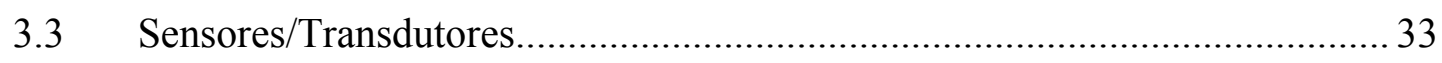

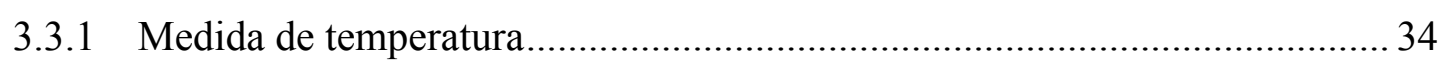

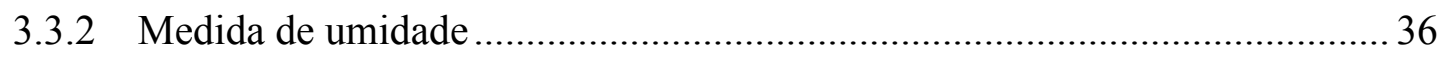




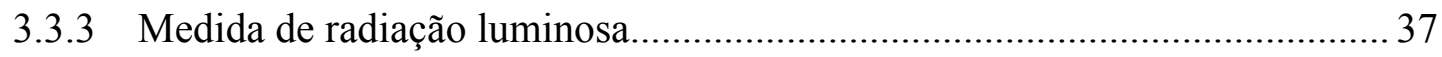

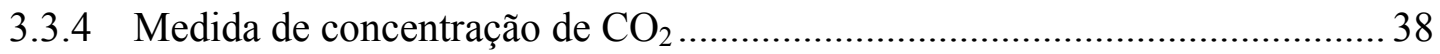

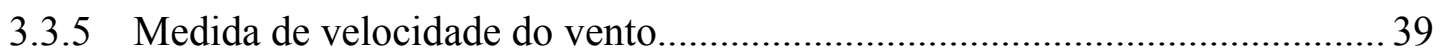

3.3.6 Medida de direção do vento .................................................................... 41

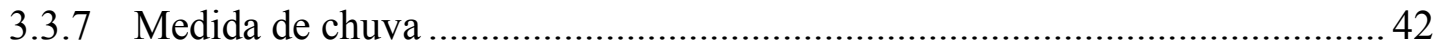

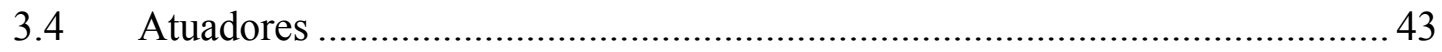

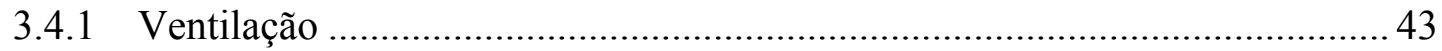

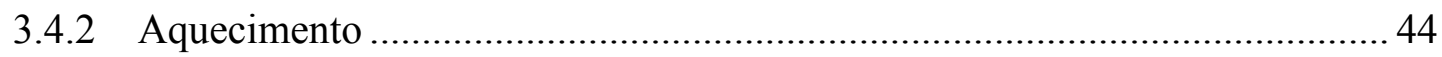

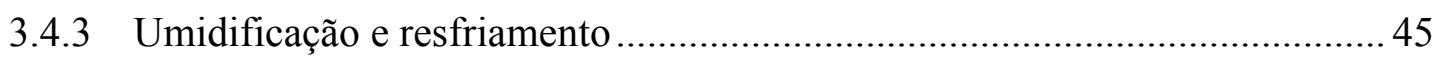

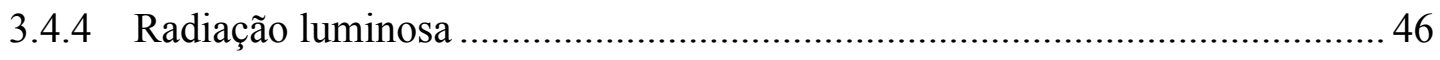

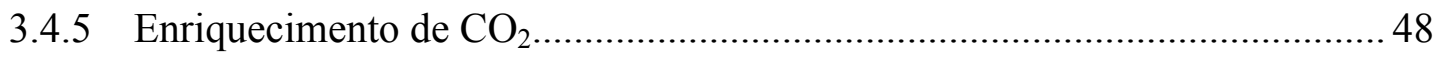

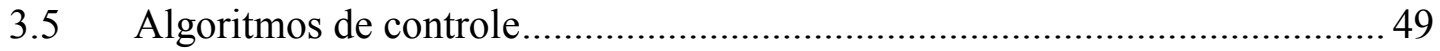

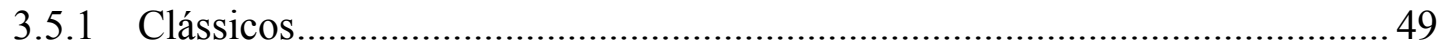

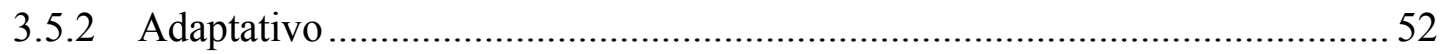

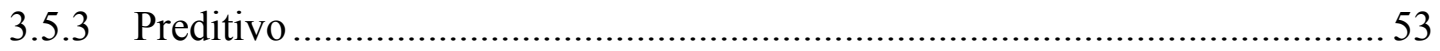

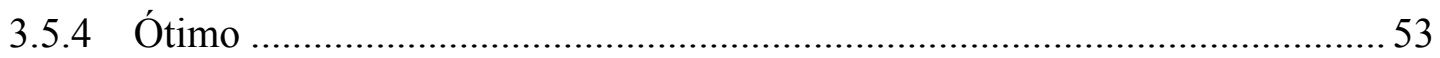

4 AGRILOGIC - SISTEMA PARA EXPERIMENTAÇÃO DE CONTROLE CLIMÁTICO DE CASAS DE VEGETAÇÃO ......................................................... 54

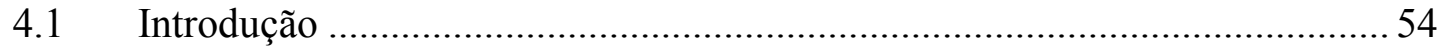

4.2 Arquitetura e Organização .......................................................................... 56

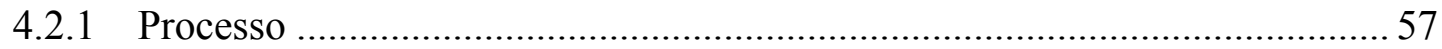

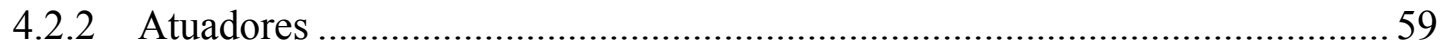

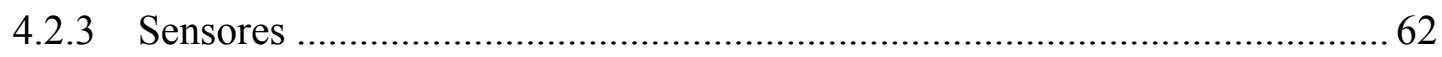

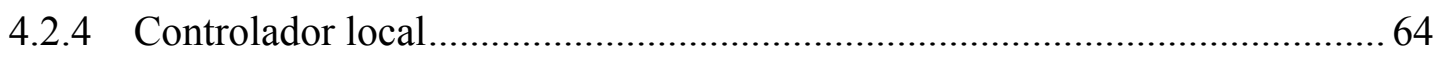

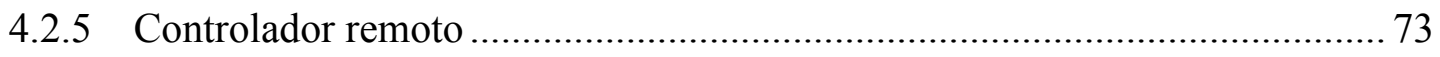

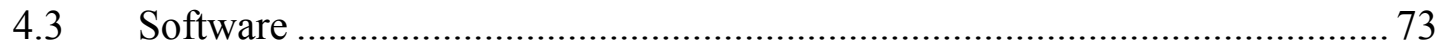

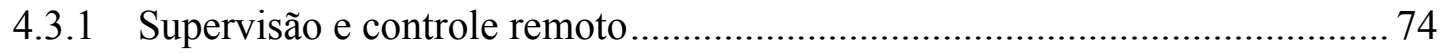

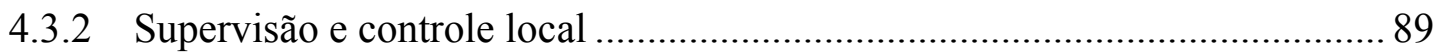

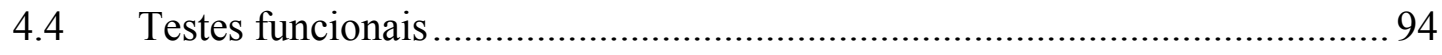

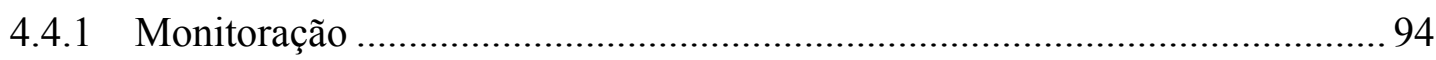

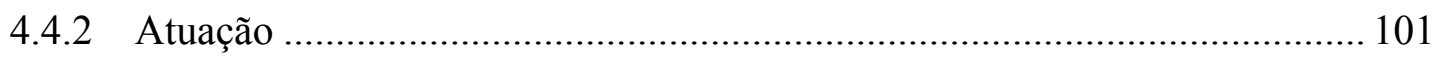

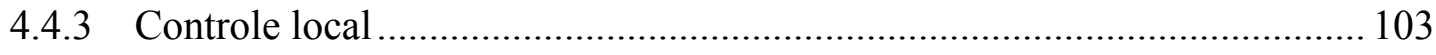




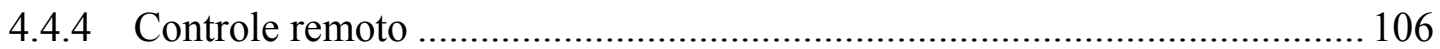

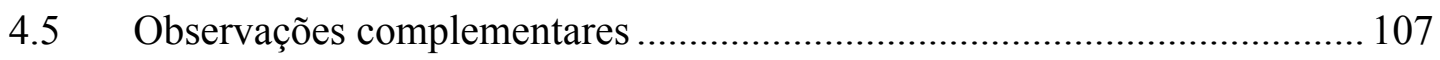

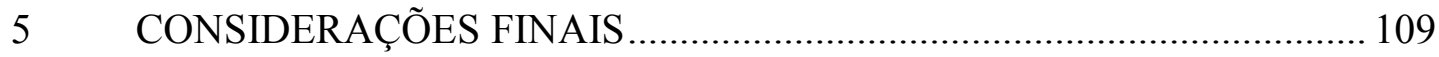

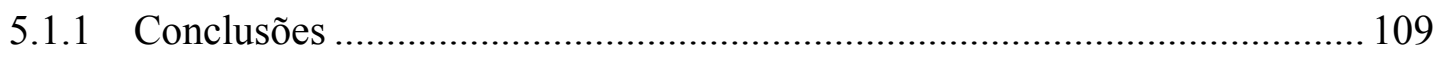

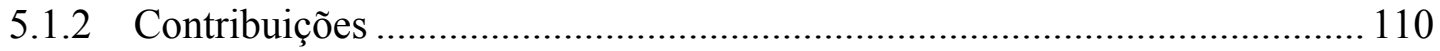

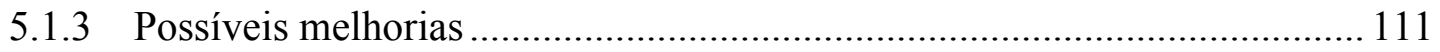

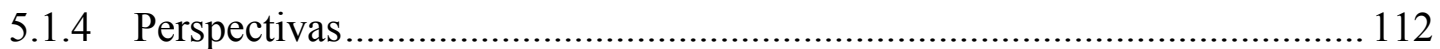

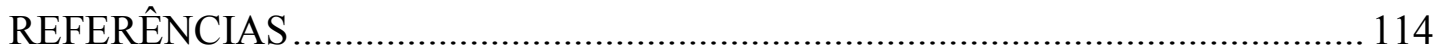

APÊNDICE 


\section{LISTA DE FIGURAS}

p.

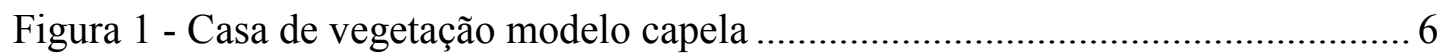

Figura 2 - Casa de vegetação modelo teto em arco.................................................... 6

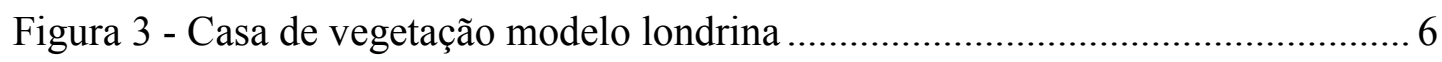

Figura 4 - Casa de vegetação modelo túnel forçado .................................................. 6

Figura 5 - Casa de vegetação modelo túnel alto ...................................................... 7

Figura 6 - Casa de vegetação modelo teto convectivo ................................................ 7

Figura 7 - Efeitos na diminuição dos valores do DIF .............................................. 12

Figura 8 - Desenvolvimento comparativo do crisântemo Yellow Delaware com e sem

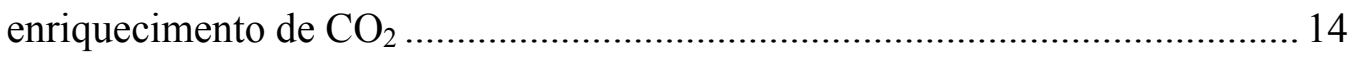

Figura 9 - Curva de crescimento vegetal em função da concentração de $\mathrm{CO}_{2} \ldots \ldots \ldots . .14$

Figura 10 - Sistema de Controle Climático Genérico ................................................ 16

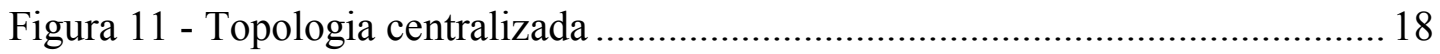

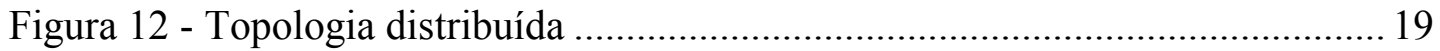

Figura 13 - Produto Growmaster Procom ……...................................................... 21

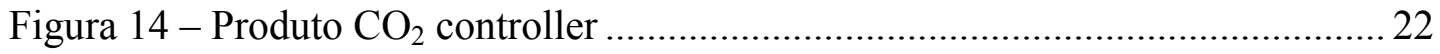

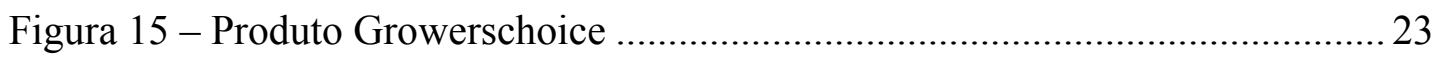

Figura 16 - Armário de CLP utilizado na automação de uma casa de vegetação em

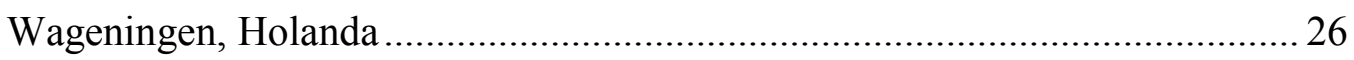

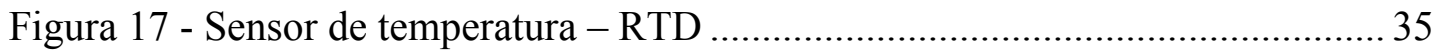

Figura 18 - Sensor de temperatura - Termistor ….................................................. 36

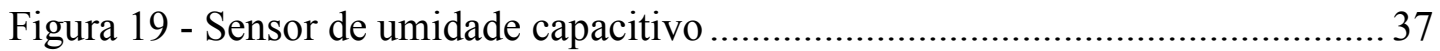

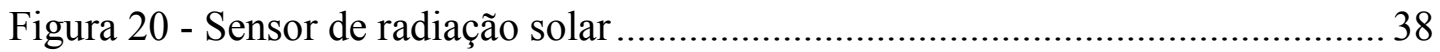

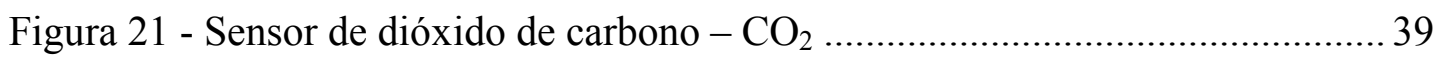

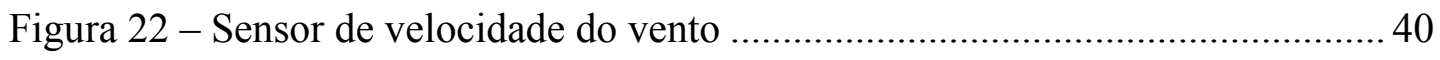


Figura 23 - Sensor de direção do vento.

Figura 24 - Sensor de intensidade de chuva tipo TBR ........................................... 42

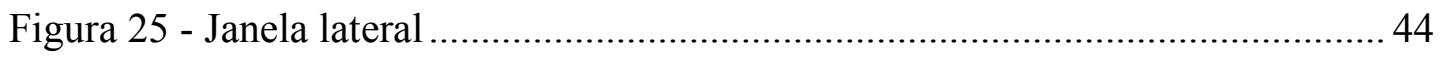

Figura 26 - Ventilador com veneziana de proteção …................................................ 44

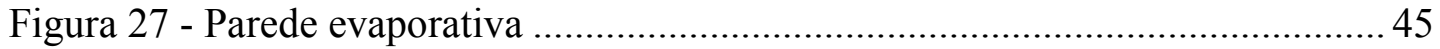

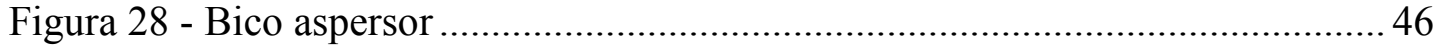

Figura 29 - Sistema de sombreamento interno...................................................... 47

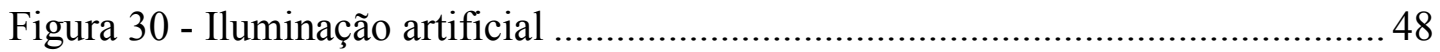

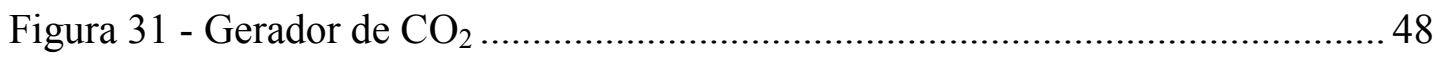

Figura 32 - Sistema de controle com realimentação ................................................. 49

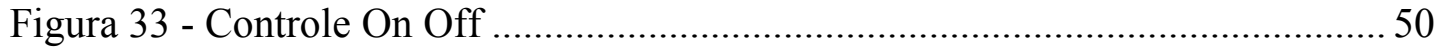

Figura 34 - Arquitetura e Organização do Agrilogic .................................................. 56

Figura 35 - Vista externa e interna da casa de vegetação do IB-USP ........................ 58

Figura 36 - Localização geográfica da casa de vegetação do IB-USP ....................... 58

Figura 37 - Ventilador da casa de vegetação IB-USP, vista interna ......................... 59

Figura 38 - Micro motor da casa de vegetação do IB-USP ......................................6 60

Figura 39 - Lâmpadas de fotoperíodo da casa de vegetação do IB-USP ................... 60

Figura 40 - Vista externa e interna do armário de controle da casa de vegetação do

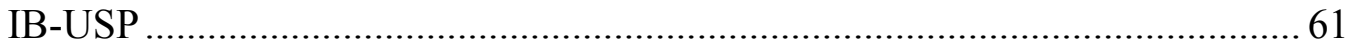

Figura 41 - Distribuição dos equipamentos da casa de vegetação do IB-USP, vista

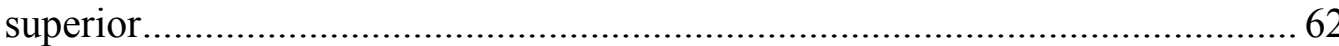

Figura 42 - Vista interna e externa dos sensores de temperatura e umidade da casa de

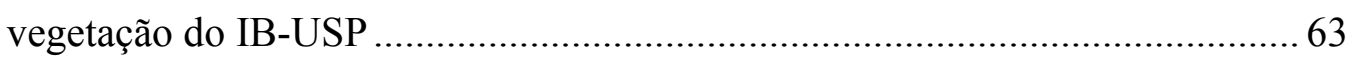

Figura 43 - Distribuição dos sensores da casa de vegetação do IB-USP ................... 64

Figura 44 - CLP PS4-201-MM1 da casa de vegetação do IB-USP ............................. 65

Figura 45 - Circuito resistivo para entrada digital - Montagem ............................... 66

Figura 46 - Circuito de relés acionadores - Montagem............................................ 67

Figura 47 - Controlador compacto PS4-201-MM1 ....................................................6 69

Figura 48 - Módulo de expansão remota para sensor de temperatura ....................... 69

Figura 49 - Módulo de expansão remota EM4-101-TX1 …..................................... 71

Figura 50 - Módulo de expansão remota para sensor de umidade ............................. 71

Figura 51 - Módulo de expansão remota EM4-101-AA2 ….................................... 73 
Figura 52 - Mapa de navegação do Agrilogic ....................................................... 76

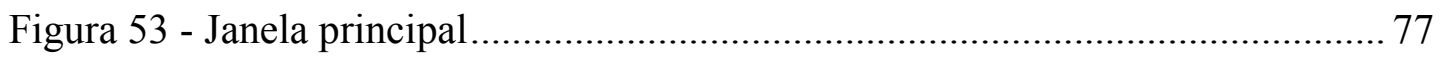

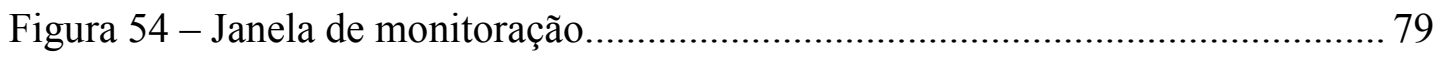

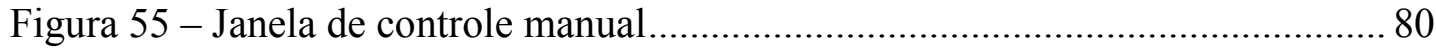

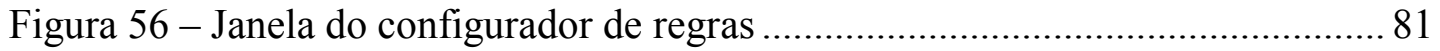

Figura 57 - Janela do configurador de regra de temperatura: single step ................. 82

Figura 58 - Janela do configurador de regra de temperatura: two step ..................... 84

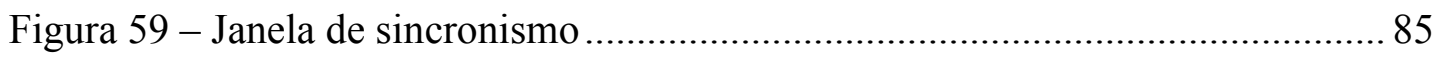

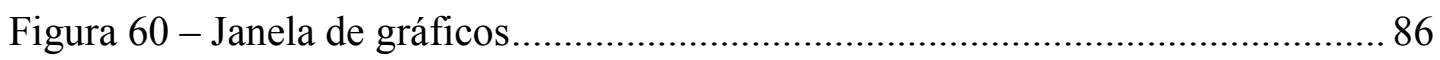

Figura 61 - Temperaturas interna e externa da casa de vegetação IB-USP............... 87

Figura 62 - Temperatura média em função do acionamento e desacionamento dos

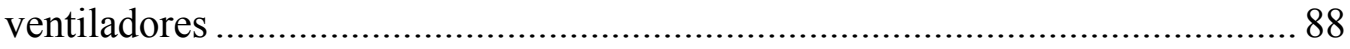

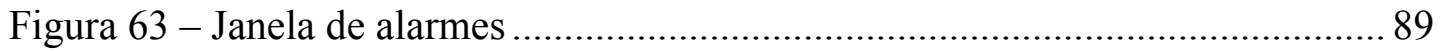

Figura 64 - Fluxograma do software de controle local do Agrilogic........................ 93

Figura 65 - Distribuição dos dispositivos de aquisição de dados na casa de vegetação

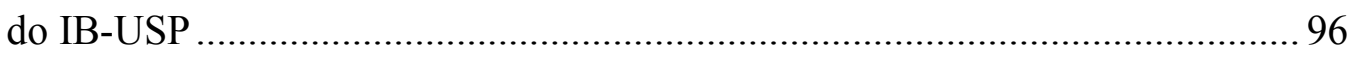

Figura 66 - Curvas de aferição da temperatura interna e externa da casa de vegetação

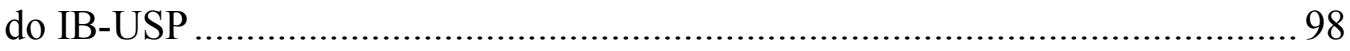

Figura 67 - Curvas de aferição da umidade interna e externa da casa de vegetação do

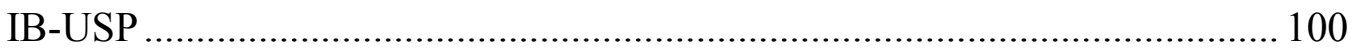

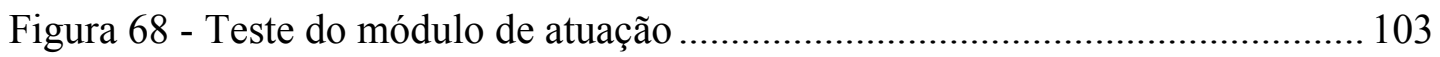




\section{LISTA DE TABELAS}

p.

Tabela 1 - Estimativa da área cultivada com hortaliças em casas de vegetação no

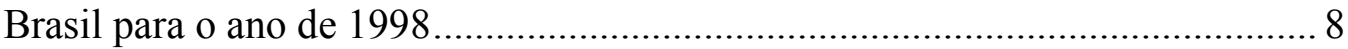

Tabela 2 - Estimativa da área cultivada com hortaliças em casas de vegetação nos principais países do mundo no início da década de 90 ....................................... 9

Tabela 3 - Resultados dos testes funcionais do módulo de monitoração .................... 95

Tabela 4 - Dados estatísticos das amostas da temperatura interna e externa da casa de

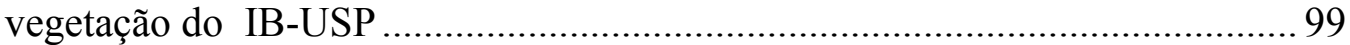

Tabela 5 - Dados estatísticos das amostas da umidade interna da casa de vegetação

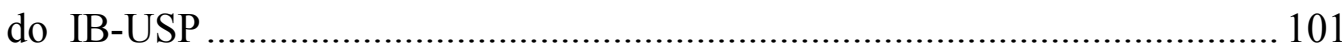

Tabela 6 - Resultados dos testes do módulo de atuação ........................................ 102

Tabela 7 - Parâmetros configurados para testes dos algoritmos "single step" e "two step" 


\section{LISTA DE ABREVIATURAS E SIGLAS}

CD-ROM: Compact Disc - Read Only Memory

CEPLA: Comité Español de Plástico en Agricultura

CLP: Controlador Lógico Programável

CV: Cavalo Vapor

DIF: Differential Between Day/Night Temperature

EC: Electrical Conductivity

HID: High Intensity Discharge

IB-USP: Instituto de Biociências da Universidade de São Paulo

IHM: Interface Homem-Máquina

IAC: Instituto Agronômico

IEC: International Electrotechnical Committee

ITE: Instituto Tecnológico Europeo, S. L.

LAA: Laboratório de Automação Agrícola

LED: Light Emitting Diode

LON: Local Operating Network 
NO: Noroeste

NTC: Negative Temperature Coefficient

PAR: Photosynthetically Active Radiation

PC: Personal Computer

PDA: Personal Digital Assistant

PID: Proporcional-Integral-Derivativo

ppm: Partes Por Milhão

PTC: Positive Temperature Coefficient

RAM: Random Access Memory

RDAC: Remote Data Acquisition and Control

RMS: Remote Measurement Systems

RPM: Rotações Por Minuto

RTD: Resistance Temperature Detector

SCADA: Supervisory Control And Data Acquisition

SE: Sudeste

SFASU: Stephen F. Austin State University

SOB: Sociedade de Olericultura Brasileira

SPWAS: Solar Powered Wireless Acquisition Station

TBR: Tipping Bucket Raingauge

USP: Universidade de São Paulo

VAC: Voltage Alternate Current 
VDC: Voltage Direct Current 
CAPÍTULO 1

\section{INTRODUÇÃO}


Este capítulo relata os objetivos e justificativas do desenvolvimento do Agrilogic, assim como a forma de organização do texto.

\section{INTRODUÇÃO}

\subsection{Objetivos}

Este trabalho tem como objetivo principal o desenvolvimento de um sistema para experimentação de controle climático de casas de vegetação, com operação remota, utilizando-se dos recursos disponíveis no LAA (Laboratório de Automação Agrícola) e no IB-USP (Instituto de Biociências da Universidade de São Paulo).

\subsection{Justificativas}

A necessidade crescente de se produzir vegetais com alta qualidade, do planejamento da produção agrícola em termos de quantidade e prazo tem levado a um aumento da utilização de diversas técnicas, sendo uma delas a de cultivo protegido, para a produção, principalmente, de hortaliças e de plantas ornamentais.

Uma outra necessidade atual é a redução dos custos por unidade de produção, com a manutenção ou aumento da qualidade.

Nesse sentido, a automação de casas de vegetação desempenha um papel fundamental, pois possibilita o controle apropriado para a produção agrícola de forma otimizada. Uma das possibilidades desse controle é a utilização racional dos recursos envolvidos. Entre eles destacam-se:

- Energia Elétrica: A utilização precisa e correta dos equipamentos envolvidos no controle proporciona a otimização do consumo de energia elétrica.

- Equipamentos: A automação permite utilizar os equipamentos de maneira mais eficaz, diminuindo o seu desgaste prematuro. 
- Insumos: A automação possibilita a redução significativa do uso de insumos agrícolas, tais como água, pesticidas, fertilizantes e reguladores químicos, entre outros, pela precisão na sua aplicação.

- Trabalho do agricultor: O controle automático permite um aumento de produtividade do agricultor, pois o libera para a realização de tarefas mais nobres, de gerenciamento, planejamento e tomada de decisão.

- Informação: A automação permite coletar, armazenar e disponibilizar informações para melhorar e facilitar o gerenciamento da produção, bem como permitir a fácil reprodução de "receitas" de sucesso.

Tendo em vista esse importante papel da automação no controle climático de casas de vegetação, este trabalho se propôs a desenvolver um sistema para experimentação de controle climático de casas de vegetação, baseando-se em equipamentos comerciais de propósito geral.

Ele foi aplicado a uma casa de vegetação do IB-USP, para avaliação e para auxílio às pesquisas lá realizadas.

A casa de vegetação é utilizada pelo IB-USP para o desenvolvimento e manutenção de plantas. A manutenção de plantas coletadas na natureza é realizada de duas formas. Na primeira, as plantas são mantidas na casa de vegetação até atingirem um tamanho suficiente para que possam ser levadas de volta ao campo e continuar seu desenvolvimento por conta própria. Na segunda, as plantas são mantidas na casa de vegetação até atingirem a maturidade e possam ser propagadas para campo através da utilização de suas partes férteis.

O presente trabalho também contribui, no LAA, para estabelecer o conhecimento básico do domínio, decorrente de uma análise realizada, e uma infra-estrutura de referência para o desenvolvimento de novos trabalhos nessa área no grupo, tais como o desenvolvimento de redes de sensores inteligentes, interligados via barramento apropriado, o desenvolvimento de diferentes algoritmos de controle, entre outros. 


\subsection{Organização do texto}

Esta dissertação é constituída por cinco capítulos.

O segundo capítulo aborda a questão do cultivo protegido e controlado, relacionando as principais formas de proteção utilizadas e mais especificamente as casas de vegetação. A questão da área cultivada no Brasil e no mundo, bem como as causas de seu atual estágio de desenvolvimento, também são discutidas. Esse capítulo relaciona ainda as principais variáveis ambientais que influenciam o desenvolvimento da planta.

O terceiro capítulo é reservado para a análise dos sistemas de controle climático de casas de vegetação na sua forma mais ampla. É realizada uma análise da arquitetura de um processo de controle de malha fechada clássico adaptado para casas de vegetação, sua topologia em termos de controle centralizado e distribuído, além da abordagem dos componentes comumente utilizados nos sistemas de controle, como: sensores, atuadores, controladores e algoritmos; também são analisados os sistemas comerciais de controle ambiental projetados especificamente para utilização em casas de vegetação.

O quarto capítulo relata sobre o sistema para experimentação de controle climático de casas de vegetação desenvolvido. Através da descrição da arquitetura e organização do sistema, são elencados os elementos utilizados na sua concepção, bem como suas interligações, tanto em nível de hardware como de software. O funcionamento do sistema é verificado por meio de testes de cada módulo envolvido: monitoração, atuação, controle local e controle remoto.

O quinto capítulo é destinado a uma análise crítica do presente trabalho, relatando as conclusões, apontando as possíveis melhorias e as perspectivas.

Finalmente o apêndice ilustra os detalhes da interligação do armário de CLP (controlador lógico programável) com o armário de comando original da casa de vegetação. 
CAPÍTULO 2

CULTIVO EM AMBIENTE PROTEGIDO E CONTROLADO 
Este capítulo aborda questões relacionadas com o cultivo em ambiente protegido e controlado, tais como técnicas, mercado e principais variáveis climáticas envolvidas.

\section{CULTIVO EM AMBIENTE PROTEGIDO E CONTROLADO}

\subsection{Introdução}

A agricultura tradicional realizada em campo aberto é dependente do meio físico natural, sendo sua prosperidade resultado das circunstâncias favoráveis do solo, clima e água, entre outros. Qualquer condição adversa de algum desses fatores pode levar ao comprometimento da produção. A tentativa de se realizar a produção agrícola com uma certa independência das condições ambientais é antiga. Segundo SFASU (Stephen F. Austin State University) (2002), o cultivo de vegetais de maneira protegida tem registro no Egito em aproximadamente 4000 a.C; através de pinturas retratando o cultivo de uvas. Existem também menções de ocorrências de cultivo protegido na China, na Grécia e na Itália já antes de Cristo. Com o passar dos tempos e com o desenvolvimento das tecnologias, foi se aprimorando também a forma de proteção.

Segundo Vecchia e Koch (1999), a expressão cultivo protegido tem um significado bastante amplo englobando um conjunto de práticas e tecnologias utilizadas pelos produtores para um cultivo mais seguro e protegido de suas lavouras. Por exemplo: quebra-ventos, mulches ${ }^{1}$ de solo, guarda-chuva, casas de vegetação, túneis altos, túneis baixos e irrigação, entre outras.

\footnotetext{
${ }^{1}$ Mulch é uma técnica de cobertura do solo, por exemplo, com filme plástico preto, com o objetivo de controlar a temperatura e a umidade no terreno dos canteiros, aumentar sua capacidade de armazenamento hídrico, bem como evitar o desenvolvimento de ervas daninhas.
} 
Essas práticas e tecnologias permitem alterar as condições naturais do ambiente que envolve a planta, proporcionando o desenvolvimento da cultura com certo domínio desses fatores climáticos.

Um dos fatores que têm impulsionado o crescimento do cultivo protegido é a utilização de plásticos, que proporcionam uma opção econômica em comparação com outros materiais normalmente utilizados para esse fim, como o vidro, a fibra-devidro, o acrílico e o policarbonato, entre outros. A técnica de se utilizar plástico na agricultura é conhecida como plasticultura. De forma semelhante ao cultivo protegido, a expressão plasticultura tem sido utilizada com um significado bastante amplo. Essa expressão, na realidade, refere-se à utilização de produtos derivados de polímeros plásticos, tais como filmes plásticos, telas e tubos de irrigação, entre outros, no sistema de cultivo de plantas. Não é raro se encontrar, na literatura disponível sobre o assunto, a utilização dos termos cultivo protegido e plasticultura como sinônimos, referindo-se na realidade a uma forma particular de proteção, conhecida comercialmente como estufa.

Segundo Reis e Makishima (2002), a casa de vegetação (greenhouse) é uma estrutura construída a partir de diversos materiais como madeira, concreto, ferro e alumínio, entre outros, cobertos com materiais transparentes que permitam a passagem da luz solar para o crescimento e desenvolvimento dos vegetais, como hortaliças, flores e outros congêneres. Essas estruturas podem ser utilizadas para proteção de forma parcial ou total. Quando utilizada de forma parcial, como por exemplo, só com a cobertura, sem proteção lateral, dá se o nome de guarda-chuva, pois seu objetivo principal é proteger a cultura contra precipitações. Quando utilizada de forma total, ou seja, com todo o potencial que a estrutura oferece para a proteção contra a ação de fatores meteorológicos, é conhecida como casa de vegetação. Essas estruturas são também conhecidas comercialmente como estufas, devido à existência do efeito estufa nessa estrutura, sendo o termo estufa utilizado no mercado independente de o grau de proteção ser parcial (guarda-chuva) ou total.

As casas de vegetação podem ser classificadas, com relação ao controle dos fatores meteorológicos, em climatizadas, semiclimatizadas e não-climatizadas. As climatizadas são aquelas que possuem um sistema que permite o controle mais amplo 
do clima. As semiclimatizadas são aquelas dotadas de grau de automação parcial de apenas alguns fatores climáticos. E finalmente as não-climatizadas são aquelas que não utilizam nenhum tipo de equipamento, ficando condicionadas aos fatores físicos da própria natureza do ambiente.

No Brasil, com relação ao formato das estruturas, as casas de vegetação podem ser classificadas em diferentes modelos: capela (figura 1), teto em arco (figura 2), londrina (figura 3), dente-de-serra, túnel forçado (figura 4), túnel alto (figura 5) e teto convectivo (figura 6).

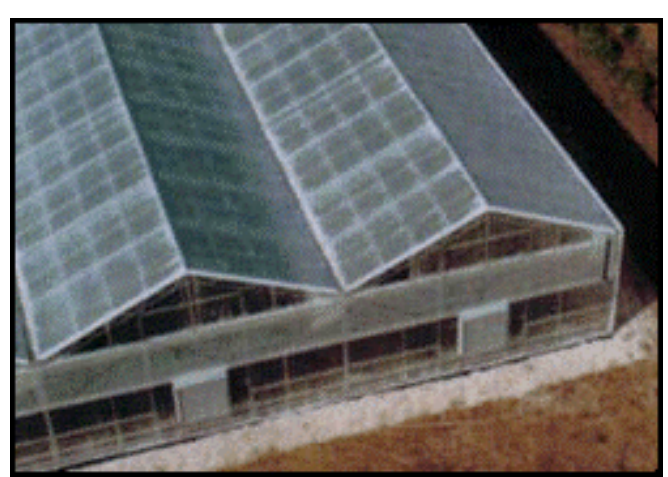

Fonte: Agrinther-a (2003)

Figura 1 - Casa de vegetação modelo capela

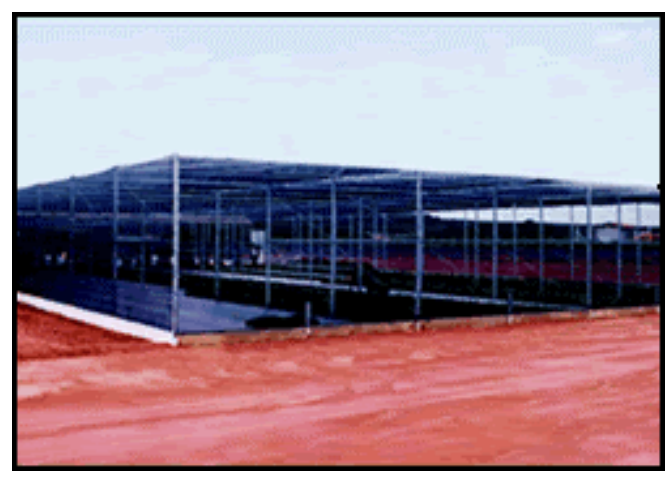

Fonte: Van der Hoven-b (2003)

Figura 3 - Casa de vegetação modelo londrina

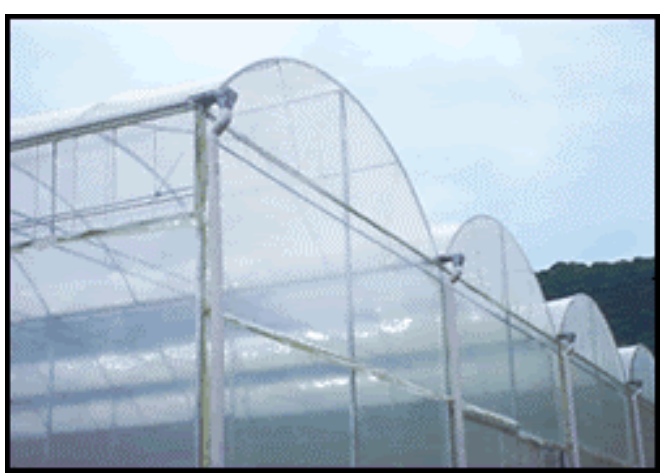

Fonte: Van der Hoven-a (2003)

Figura 2 - Casa de vegetação modelo teto em arco

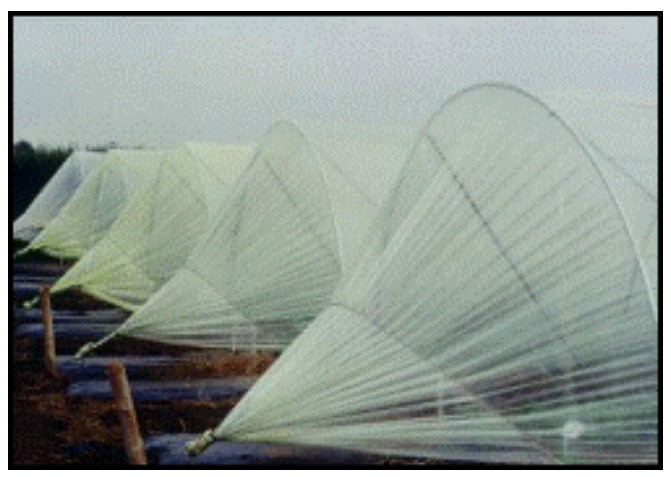

Fonte: Tropical-a (2003)

Figura 4 - Casa de vegetação modelo túnel forçado 


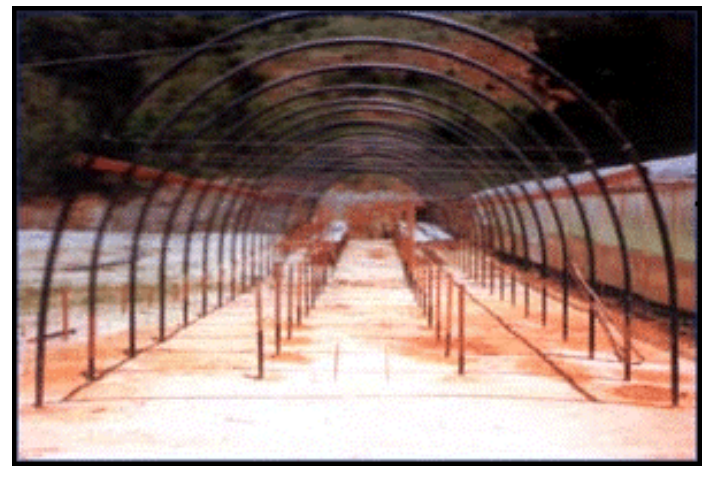

Fonte: Hidrogood (2003)

Figura 5 - Casa de vegetação modelo túnel alto

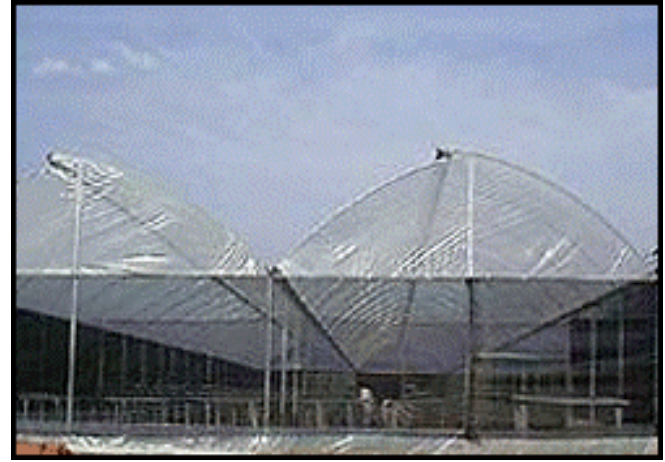

Fonte: Tropical-b (2003)

Figura 6 - Casa de vegetação modelo teto convectivo

Segundo Oliveira et al (1997), existem casas de vegetação altamente automatizadas utilizadas geralmente na produção de flores e plantas ornamentais, as quais exigem um controle mais rígido das condições ambientais. A agregação de custos é viável devido ao alto retorno financeiro desses tipos de cultura.

No Brasil, de acordo com Vecchia e Koch (1999), estimativas levantadas em 1994 apontavam para uma área de hortaliças cultivada através da utilização de casas de vegetação em torno de 2 mil hectares, com uma previsão de crescimento anual de $30 \%$, sendo que projeções para a virada do milênio indicavam uma área potencial de 10 mil hectares. Porém, de acordo com o levantamento efetuado em 1999, cerca de 1.390 ha de hortaliças foram cultivados com esse sistema no ano de 1998. Os Estados de São Paulo, Paraná e Rio Grande do Sul foram os Estados com maior área de produção, destacando-se o cultivo de pimentão, de alface, de tomate e de pepino. A tabela 1 mostra a estimativa da área cultivada com hortaliças em casas de vegetação no Brasil para o ano de 1998. 
Tabela 1 - Estimativa da área cultivada com hortaliças em casas de vegetação no Brasil para o ano de 1998

\begin{tabular}{|l|c|l|}
\hline \multicolumn{1}{|c|}{ Estado } & Área (ha) & \multicolumn{1}{c|}{ Culturas $^{(\mathbf{( 1 )}}$} \\
\hline São Paulo & 550 & Pimentão, tomate, pepino, alface, folhosas \\
\hline Paraná & 240 & Alface, pepino, tomate, pimentão. \\
\hline Rio Grande do Sul & 200 & Alface, tomate, pepino, pimentão. \\
\hline Mato Grosso do Sul & 100 & Alface, melão, pepino, tomate. \\
\hline Rio de Janeiro & 100 & Pimentão, tomate, alface, jiló. \\
\hline Distrito Federal & 70 & Pimentão, folhosas, tomate, pepino. \\
\hline Santa Catarina & 50 & Tomate, alface, pepino, pimentão. \\
\hline Minas Gerais & 20 & Alface, pimentão, tomate, folhosas. \\
\hline Espírito Santo & 10 & Pimentão, alface, tomate, pepino. \\
\hline Outros & 50 & - \\
\hline Total: & $\mathbf{1 . 3 9 0}$ & - \\
\hline
\end{tabular}

Fonte: Vecchia e Koch (1999).

(1) Culturas em ordem aproximada de importância.

(2) Entre as folhosas incluem-se principalmente o agrião, almeirão, rúcula, espinafre japonês e algumas espécies condimentares (cebolinha, salsa e coentro, entre outras).

Para se ter uma idéia comparativa da realidade brasileira, a tabela 2 mostra uma estimativa da área cultivada com hortaliças em casas de vegetação nos principais países do mundo no início da década de 90. Apesar dessa tabela mostrar uma situação antiga, é possível constatar que temos uma área relativamente pequena cultivada nesse sistema. O CEPLA-a (Comité Español de Plástico en Agricultura) (2002), embasado em dados mais atualizados, relata que a superfície total coberta por plásticos na Espanha em 1999 era de aproximadamente de 190.000 hectares, e mais especificamente na região de Almeria, conhecida como "mar de plástico", se encontra a maior concentração de casas de vegetação do mundo, com 30.000 hectares de área coberta. 
Tabela 2 - Estimativa da área cultivada com hortaliças em casas de vegetação nos principais países do mundo no início da década de 90.

\begin{tabular}{|l|c|l|}
\hline \multicolumn{1}{|c|}{ País } & Área (ha) & \multicolumn{1}{c|}{ Culturas $^{(\mathbf{1})}$} \\
\hline China & 62.000 & $\begin{array}{l}\text { Pepino, tomate, morango, pimentão, berinjela, } \\
\text { cebola, cebolinha, vagem, couve-chinesa, abóbora. }\end{array}$ \\
\hline Japão & 30.000 & Pepino, tomate, morango, melão. \\
\hline Espanha & 24.000 & $\begin{array}{l}\text { Melancia, pimentão, melão, morango, tomate, } \\
\text { pepino, abóbora. }\end{array}$ \\
\hline Itália & 21.000 & Tomate, morango, pimentão, melão, pepino. \\
\hline Grécia & 11.000 & Tomate, pepino, melão, pimentão, berinjela. \\
\hline Argélia & 10.000 & Tomate, pepino, melão. \\
\hline França & 6.000 & Tomate, pepino, morango. \\
\hline Egito & 6.000 & Tomate, pepino, melão. \\
\hline Portugal & 5.000 & Melão, morango, tomate, pimentão. \\
\hline Coréia do Sul & 4.000 & Pepino, tomate, vagem, repolho. \\
\hline Marrocos & 3.400 & Tomate, pepino, pimentão, berinjela. \\
\hline Turquia & 3.000 & Tomate, pepino, melão, berinjela, pimentão. \\
\hline Rússia & 3.000 & Pepino, cebola, tomate, morango. \\
\hline $\begin{array}{l}\text { Reino Unido, } \\
\text { Holanda, Bélgica, } \\
\text { Escandinávia e } \\
\text { Alemanha. }\end{array}$ & 6.000 & Tomate, pepino, alface, morango. \\
\hline Total: & $\mathbf{1 9 4 . 4 0 0}$ & \\
\hline
\end{tabular}

Fonte: Vecchia e Koch (1999).

(1) Culturas em ordem aproximada de importância.

Segundo Vecchia e Koch (1999), diversos fatores têm sido apontados como responsáveis pelo baixo crescimento do cultivo de hortaliças através da utilização de casas de vegetação no Brasil. Entre eles destacam-se os seguintes:

- Equívocos ou má fé na divulgação da tecnologia - a falta de respaldo de informações adequadas previamente testadas pela pesquisa agrícola, resultaram em experiência negativas para muitos agricultores, que geraram descrença nesse sistema de produção.

- Falta de integração entre instituições públicas de pesquisas, extensão rural, produtores e empresas privadas para a divulgação de resultados de pesquisas, introdução de novas tecnologias e fomento da plasticultura. 
- Dificuldade no estabelecimento e/ou superação de problemas relacionados com a comercialização diferenciada de hortaliças produzidas com essa técnica, de forma que justifiquem e estimulem o investimento na tecnologia.

- Profunda crise sócio-econômica experimentada pelo Brasil ao longo das últimas duas décadas, com grave conseqüência no crescimento do consumo, no custo e na disponibilidade de crédito para investimento agrícola.

Além dos pontos destacados acima, a falta de experiência de muitos produtores, mais especificamente em relação à classificação, embalagem e comercialização diferenciada desses produtos, contribui para o insucesso e a descrença na utilização dessa técnica. Finalmente, a questão da competição com produtos cultivados em campo aberto é abordada, pois tendo o país dimensões continentais e sua extraordinária diversidade climática, a produção de hortaliças com qualidade a campo aberto é quase sempre possível, chegando em alguns casos a uma qualidade comparável, em aparência, às produzidas em casas de vegetação.

Apesar do baixo crescimento do cultivo de hortaliças em casas de vegetação, as perspectivas futuras são promissoras. Os seguintes fatores embasam esse otimismo:

- O número de trabalhos sobre cultivo de hortaliças utilizando a técnica de casas de vegetação apresentados nos congressos da SOB (Sociedade de Olericultura Brasileira) de 1995 a 1998 foi de 72, bastante superior àquele apresentado nos período de 1985 a 1994, que foi de 46, ou seja, em quatro anos produziram-se mais trabalhos do que em uma década.

- $\mathrm{O}$ amadurecimento em relação às potencialidades da nova tecnologia de produção, tanto entre produtores, como entre profissionais das esferas públicas e privadas responsáveis pelo fomento da atividade.

- Observou-se nos últimos anos um crescente interesse dos grandes supermercados no segmento de hortifrutigranjeiros, os quais exigem qualidade e escala, forçando a criação de empresas e associações de produtores interessados em atender a esse nicho de mercado. $\mathrm{O}$ cultivo de hortaliças em casas de vegetação vem ao encontro dessa nova realidade, 
garantindo qualidade e volumes necessários, particularmente para algumas espécies de hortaliças que apresentam uma entressafra bem definida.

\subsection{Variáveis climáticas}

Segundo Lorenzo (2001), as principais variáveis climáticas envolvidas no processo de produção vegetal em casas de vegetação são: a temperatura, a umidade relativa, a radiação luminosa e a concentração de $\mathrm{CO}_{2}$ (Dióxido de Carbono). Segundo Infoagro-a (2002), as presenças desses fatores dentro de certos limites mínimos e máximos, proporcionam condições propícias para o desenvolvimento da planta, enquanto fora desses limites, o desenvolvimento é prejudicado, podendo levar até mesmo à sua morte.

\subsubsection{Temperatura}

A temperatura é um fator determinante da atividade metabólica, de crescimento e desenvolvimento do vegetal. Para a manipulação da temperatura é importante conhecer as limitações e necessidades de cada espécie cultivada. Por exemplo, as hortaliças comestíveis como pimentão, tomate, berinjela e pepino, entre outras, possuem uma necessidade mínima de temperatura em torno de $12{ }^{\circ} \mathrm{C}$, abaixo da qual ocorre um decréscimo no crescimento e apresentam sintomas de deterioração. Por outro lado, a partir de um determinado valor, que oscila entre $35-40{ }^{\circ} \mathrm{C}$, se reduz a síntese protéica. Do ponto de vista da temperatura, são parâmetros importantes:

- Temperaturas máximas e mínimas biológicas - São valores específicos para o alcance de uma determinada fase vegetativa, como a floração e frutificação, entre outras.

- Temperaturas diurnas e noturnas - Níveis recomendados para o correto desenvolvimento do vegetal.

Segundo Blom (2002) e Nelson (1991), a temperatura do ar também pode ser utilizada para controlar a forma e morfologia do vegetal. O termo "DIF" (Differential Between Day/Night Temperature) é definido como sendo a temperatura diferencial entre o dia e a noite, podendo ser positivo (+DIF) ou negativo (-DIF). Algumas 
espécies de vegetais submetidas a um regime de DIF positivo apresentam elongação do caule (crescimento), folhas verdes e saudáveis, e quando submetidas a um regime de DIF negativo, diminuem a elongação do caule, promove-se o amarelamento e a quedas das folhas. O DIF é utilizado para controlar a altura de algumas espécies de vegetais. A figura 7 mostra o efeito de valores decrescentes de DIF, da esquerda para a direita, na morfologia da flor Lírio, para uma temperatura diurna fixa de $26^{\circ} \mathrm{C}$.

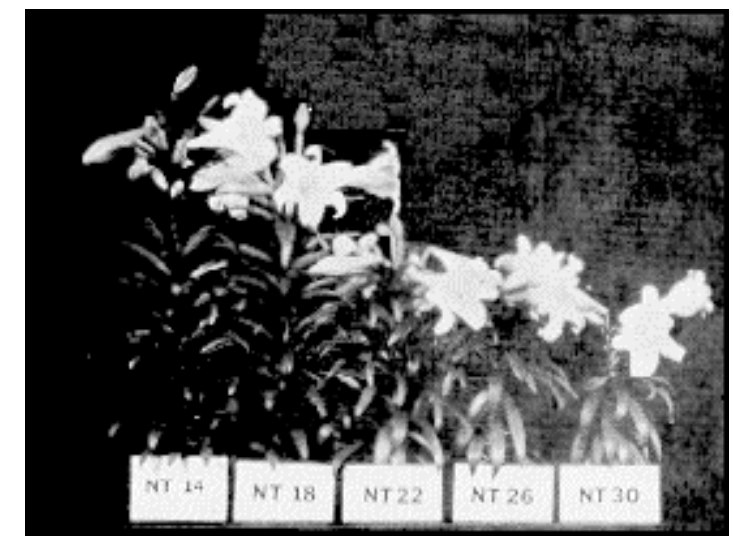

Fonte: Nelson $(1991)-($ Obs. NT $=$ Night Temperature $)$

\section{Figura 7 - Efeitos na diminuição dos valores do DIF}

\subsubsection{Umidade relativa}

A umidade relativa está relacionada com o rendimento dos vegetais. Quando ela é elevada, os vegetais reduzem a transpiração, e conseqüentemente, diminuem o crescimento, podendo ocorrer inclusive abortos florais e um aumento das enfermidades causadas por fungos, por bactérias e até mesmo por algas. Esses tipos de enfermidades também são conhecidos por enfermidades criptogâmicas. Por outro lado, quando a umidade relativa é baixa os vegetais transpiram em excesso, podendo ocorrer a desidratação.

\subsubsection{Radiação luminosa}

A radiação luminosa é o componente essencial para a ocorrência da fotossíntese, que é um processo de síntese orgânica realizado por vegetais portadores de clorofila. Segundo CEPLA-b (2002), o Sol é o principal fornecedor de energia radiante, que atinge a Terra principalmente na forma de radiação nas faixas do ultravioleta, visível 
e infravermelho. No espectro de freqüência da radiação solar, existe uma faixa particular, entre 400-700 nm, na qual ocorre o processo de fotossíntese. Essa faixa é conhecida como radiação fotossinteticamente ativa, representada comumente pela sigla inglesa PAR (Photosynthetically Active Radiation). Apenas para referência convém observar que a radiação visível está situada entre 380-760 nm.

Existem duas dimensões da radiação que devem ser ressaltadas. A primeira é a intensidade da luz e a segunda é o fotoperíodo (período de duração da luz). A intensidade é responsável pela maximização do crescimento da planta e o fotoperíodo é responsável pelo metabolismo. Segundo Nelson (1991), o fotoperiodismo é a reação da planta ao ciclo de dia-e-noite. Essa reação pode se dar de diversas formas, entre elas: formação do bulbo em cebola, florescimento de crisântemos e mudança na morfologia de folhas novas. Portanto, um ciclo importante a ser controlado pela radiação é o fotoperíodo. O controle da radiação é benéfico como um complemento para locais com baixo nível de luz natural. Pode ser utilizado para estender a duração natural do dia, alterando com isso a resposta da planta devido ao fotoperiodismo.

\subsubsection{Concentração de $\mathrm{CO}_{2}$}

Segundo Nelson (1991), o carbono é um nutriente essencial dos vegetais e é o de maior concentração na planta. Existem estudos que mostram que em torno de $40 \%$ da planta seca é composta de carbono. A planta obtém o carbono presente no $\mathrm{CO}_{2}$ atmosférico através da fotossíntese; portanto uma boa estratégia de enriquecimento de $\mathrm{CO}_{2}$ no ar torna-se interessante. A concentração ideal de $\mathrm{CO}_{2}$ no ar é dependente do tipo de cultura, porém para todas existe um ponto ótimo. A maioria das culturas é beneficiada com concentrações de $\mathrm{CO}_{2}$ entre 1000 e 1500 ppm (partes por milhão), existindo algumas espécies que respondem de maneira positiva a concentrações de até $1800 \mathrm{ppm}$. A figura 8 mostra o desenvolvimento comparativo do crisântemo, sendo que o da esquerda foi cultivado em um ambiente enriquecido com $\mathrm{CO}_{2}$ e o da direita não. 


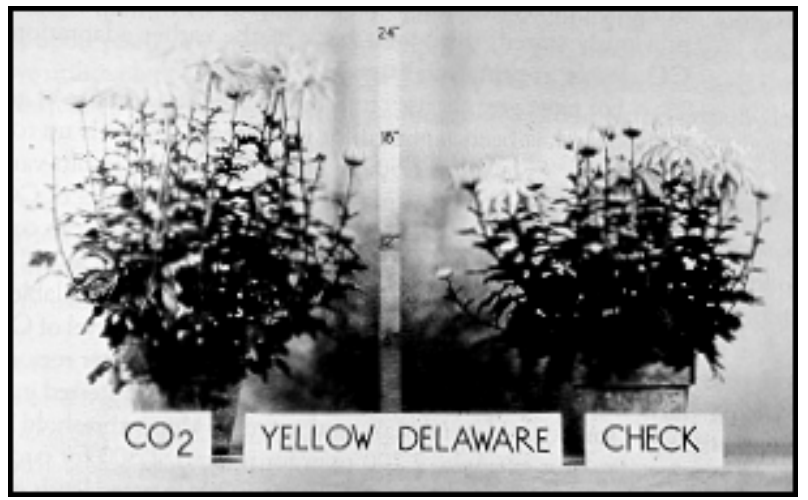

Fonte: Nelson (1991)

Figura 8 - Desenvolvimento comparativo do crisântemo Yellow Delaware com e sem enriquecimento de $\mathrm{CO}_{2}$

De acordo com Thayer (2003), o crescimento vegetal em função da concentração de $\mathrm{CO}_{2}$ pode ser visualizado através da figura 9. O ponto de concentração de $\mathrm{CO}_{2}$ de 300 ppm é adotado como padrão para o crescimento de 100\% pois é a quantidade desse gás presente na atmosfera. Para concentrações abaixo de 200 ppm, a planta não tem $\mathrm{CO}_{2}$ suficiente para realizar o processo de fotossíntese e em conseqüência não ocorre o crescimento. Pode-se notar pela curva que aumentando a concentração de $\mathrm{CO}_{2}$ ocorre um crescimento acentuado, chegando em determinadas concentrações a ocorrer um crescimento maior que o dobro para a maioria das plantas. Acima da concentração de 2000 ppm o ambiente torna-se tóxico para as plantas e acima de 4000 ppm ele também fica tóxico para o ser humano.

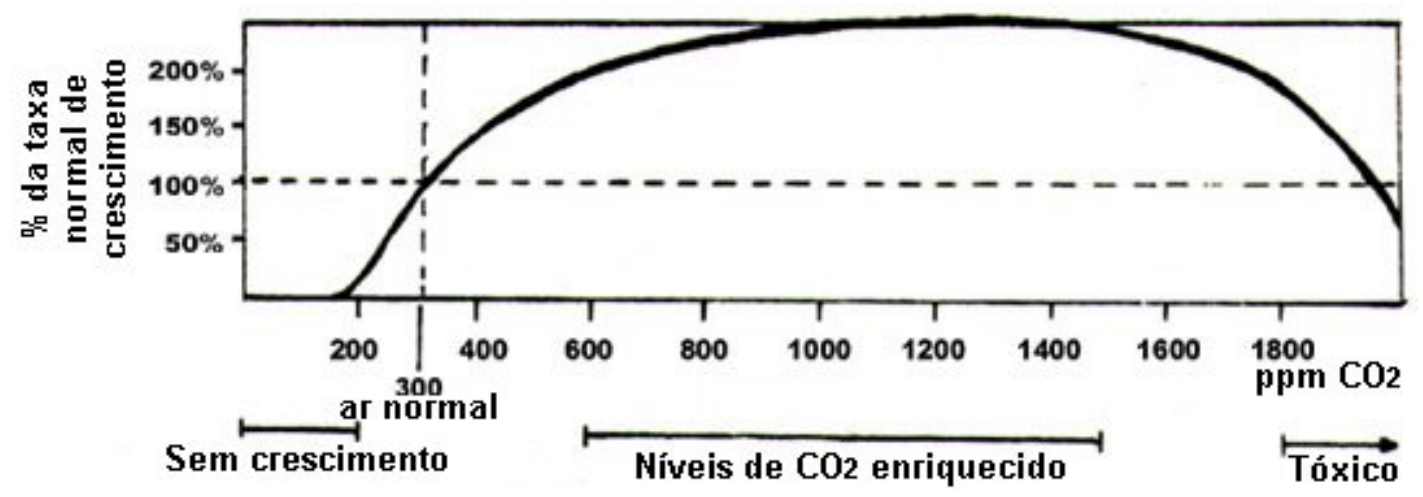

Fonte: Thayer (2003)

Figura 9 - Curva de crescimento vegetal em função da concentração de $\mathrm{CO}_{2}$ 


\section{CAPÍTULO 3}

SISTEMAS DE CONTROLE CLIMÁTICO DE CASAS DE VEGETAÇÃO 


\section{SISTEMAS DE CONTROLE CLIMÁTICO DE CASAS DE VEGETAÇÃO}

Segundo Moraes e Castrucci (2001), um sistema é considerado dinâmico se ele estiver em constante evolução no tempo. Todos os fenômenos, térmicos, químicos, fisiológicos e ecológicos, entre outros, os quais são regidos por equações diferenciais em que o tempo é a variável independente, são considerados sistemas “intrinsecamente dinâmicos". Um modelo eficiente de controle para esses sistemas é através da utilização da realimentação, que consiste na utilização deliberada de medidas das saídas do sistema a fim de melhorar seu desempenho operacional.

Nesse sentido uma casa de vegetação pode ser considerada um sistema dinâmico, pois está sempre em evolução no tempo. O controle do clima, sem a intervenção humana, geralmente é realizado com utilização de circuitos eletrônicos e da automação.

\subsection{Arquitetura}

Um sistema genérico para controlar automaticamente o clima no interior de uma casa de vegetação utiliza uma malha de realimentação, pela qual cada variável a ser controlada é monitorada e seu valor é comparado com um valor de referência, gerando um sinal de controle que procurará minimizar a diferença entre os dois valores. Figura 10. 


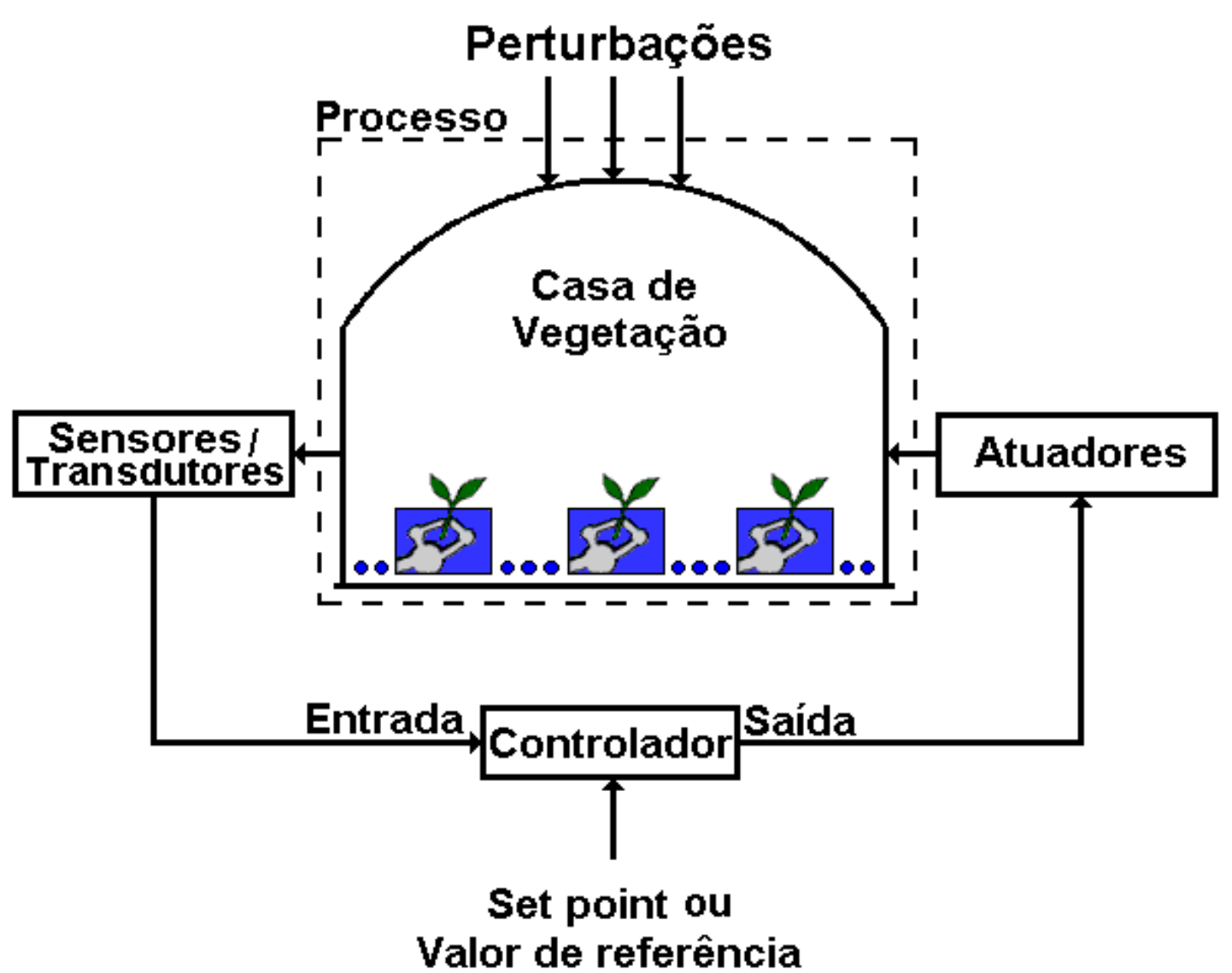

Figura 10 - Sistema de Controle Climático Genérico

Esquematicamente o sistema pode ser dividido em quatro partes:

- Processo - É a casa de vegetação e as variáveis a serem controladas. Por exemplo: temperatura, umidade relativa, concentração de $\mathrm{CO}_{2}$ e radiação luminosa, entre outros.

- Sensores/Transdutores - Dispositivos que realizam a medição dos valores das variáveis controladas no sistema. Por exemplo: sensor de temperatura, de umidade e de radiação, entre outros.

- Controlador - Elemento que compara o valor atual das variáveis a controlar, fornecido pelos sensores, com o valor de referência, e executa o algoritmo de controle. Emite os sinais de saída para os atuadores visando a corrigir o valor da variável para que os erros sejam os mínimos possíveis. Como exemplos, 
temos os computadores de uso geral com placas apropriadas, computadores dedicados e CLP, entre outros.

- Atuadores - Recebem os sinais de controle fornecidos pelo controlador e agem sobre o meio físico, visando manter as variáveis controladas dentro dos limites desejados. Por exemplo: sistemas de resfriamento, telas de sombreamento e umificadores, entre outros.

\subsubsection{Sistemas de controle centralizados e distribuídos}

Segundo Hanan (1998), os sistemas de controle, em função do local do processamento dos dados envolvidos no processo, podem ser classificados em duas topologias básicas: centralizada e distribuída.

- Nos sistemas de controle com topologia centralizada, todos os elementos envolvidos estão interligados e o processamento das informações é executado em apenas um local, ou seja, no computador central. Nessa topologia todos os cabos dos sensores e atuadores são centralizados em um único ponto no qual está localizado o computador, o dispositivo de aquisição e controle.

A vantagem dessa topologia, em função de todos os elementos estarem juntos, é que o computador e o dispositivo de aquisição e controle podem ser instalados em um ambiente separado do processo. As casas de vegetação não são os locais mais apropriados para a colocação de equipamentos eletrônicos devido ao calor, a umidade e aos poluentes aéreos emitidos durante a nebulização e à irrigação. Portanto, o sistema pode ser colocado em um local apropriado e protegido contra essas adversidades, caso seja necessário.

A desvantagem dessa topologia é a necessidade da utilização de uma grande quantidade de cabos, sendo que parte desses cabos necessita de blindagem para evitar interferência eletromagnética, pois conduzem sinais provenientes de sensores, na ordem de milivolts. Além disso, existe um aumento na probabilidade de danos aos cabos e problemas de aterramento devido à distância. $\mathrm{O}$ custo dos condutores e a possibilidade de interferência eletromagnética devem ser levados em conta nessa topologia. 
Esse tipo de topologia permite o controle de uma ou várias casas de vegetação, dependendo apenas da capacidade de processamento do computador central e das distâncias dos sensores e atuadores. A figura 11 representa uma topologia centralizada no qual o computador central recebe e emite sinais de/para várias casas de vegetação simultaneamente. Esse computador central pode inclusive estar em ambiente apropriado em qualquer uma das casas de vegetação.

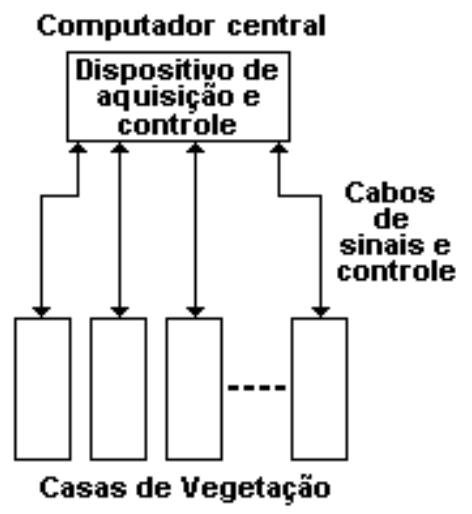

\section{Figura 11 - Topologia centralizada}

- Nos sistemas de controle com topologia distribuída o processamento das informações é realizado em mais de um local do sistema. Nesta condição, pode-se considerar como razoável a abordagem de Hanan (1998), que considera a interligação de várias casas de vegetação, cada uma equipada com seu próprio processador com capacidade de memória limitada, com teclado e com display, sendo que os dois últimos podem ser portáteis para serem utilizados sob demanda. Os valores de referência ("set points") são fornecidos para o processador local, o qual é responsável pela maioria dos controles imediatos e pela leitura dos sensores mais relevantes ao processo. $\mathrm{O}$ computador central verifica cada processador local seqüencialmente, obtém as últimas informações sobre o clima e se necessário recalcula o novo valor de referência. O operador pode fornecer comandos localmente através da configuração do processador para "modo local". No caso da ocorrência de falha no computador central, o processador local pode operar o sistema com 
uma abrangência limitada. Nessa topologia os problemas de indução de ruídos nos cabos e custos dos mesmos são menores. A comunicação entre os dispositivos de aquisição e controle é feita de forma serial, utilizando corrente elétrica de $20 \mathrm{~mA}$ e cabos de pares trançados blindados, os quais possibilitam atingir até $1 \mathrm{~km}$ entre o processador local e o computador central. Para distâncias de até 50 metros o padrão serial RS-232 pode ser utilizado. Acima dessa distância é necessária a utilização de modems. Figura 12.

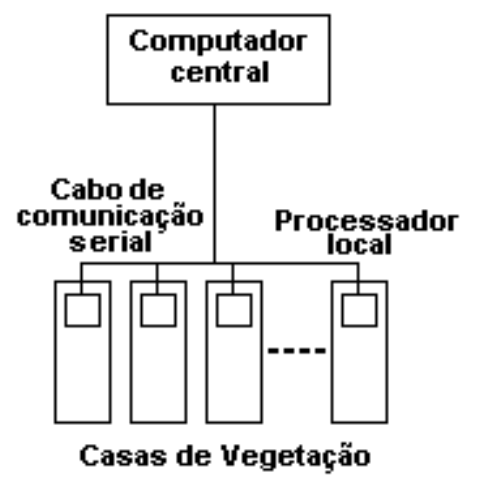

Figura 12 - Topologia distribuída

No contexto do controle distribuído, uma abordagem diferente da proposta previamente apresentada foi desenvolvida por Morais et al (1998), na qual todo o sistema de controle é modelado em três entidades: a de aquisição de dados, batizado de SPWAS (Solar Powered Wireless Acquisition Station), a estação base, batizada de RDAC (Remote Data Acquisition and Control), e finalmente a estação de gerenciamento. A estação de aquisição de dados é alimentada por bateria solar e também por uma bateria recarregável para suprir os períodos de baixa luminosidade. Ela é responsável pelo processamento dos sinais provenientes dos sensores e pelo envio das informações relativas desses sinais para a estação base por meio de rádio freqüência. A estação base, por sua vez, recebe esses sinais, os armazena, comanda os atuadores e possui capacidade de realizar algoritmos de controle simples, caso ocorra a perda de comunicação com a estação de gerenciamento. A comunicação entre a estação base e a estação de 
gerenciamento pode ser realizada por meio de rádio freqüência, de RS-485 e de RS-232. A estação de gerenciamento, por ser um computador padrão de mercado, pode se beneficiar do desenvolvimento nas tecnologias dos computadores, trazendo maior capacidade de processamento a custos cada vez menores, permitindo o processamento de algoritmos de identificação em tempo real e também de complexas estratégias de controle, tais como controles preditivos e tarefas de supervisão.

\subsection{Sistemas comerciais de controle ambiental para casas de vegetação}

O desenvolvimento da atividade de produção vegetal utilizando casas de vegetação e a necessidade do controle das variáveis ambientais para o aumento da qualidade e rentabilidade da produção têm despertado o interesse de empresas, que dominam a utilização dessas novas tecnologias de controle computadorizado, no fornecimento de equipamentos para esse mercado promissor. Essas empresas têm auxiliado na quebra do paradigma de que o setor agrícola é um dos últimos segmentos a receber os benefícios dos avanços tecnológicos. Dos produtos disponíveis alguns são baseados em equipamentos dedicados e alguns em equipamento de propósito geral.

\subsubsection{Equipamentos dedicados}

Os produtos baseados em equipamentos dedicados são projetados com a finalidade de atender às necessidades específicas de controle das variáveis climáticas mais relevantes de casas de vegetação, levando em conta todas as características inerentes a esses ambientes e as dificuldades de operação do equipamento por parte do agricultor, tornando a sua utilização bastante simples. Existe uma vasta gama de produtos para esse fim, desde equipamentos mais completos e sofisticados que controlam diversas variáveis de uma forma integrada, até equipamentos menos completos e mais simples responsáveis pelo controle de apenas uma variável ambiental.

Como exemplo de equipamento dedicado mais completo e sofisticado pode-se citar o produto Growmaster Procom da empresa Micro Grow Greenhouse Systems, Inc., figura 13. Essa classe de equipamentos permite o controle de diversos ambientes 
simultaneamente e possui vários algoritmos de controle de variáveis de forma integrada. Segundo Micro Grow (2002), o produto Growmaster Procom possui algoritmos de controle baseados nas condições ambientais internas e externas às casas de vegetação, incluindo também quatro modos de operações diárias (manhã, meio-dia, tarde e noite incluindo DIF). Os seguintes itens podem ser programados no produto: temperaturas de aquecimento e resfriamento, temperatura de ventilação, temperatura de nebulização e umidade, temperatura do sistema de aquecimento de água, intensidade da radiação do sistema de sombreamento, níveis de $\mathrm{CO}_{2}$ e níveis de umidade.

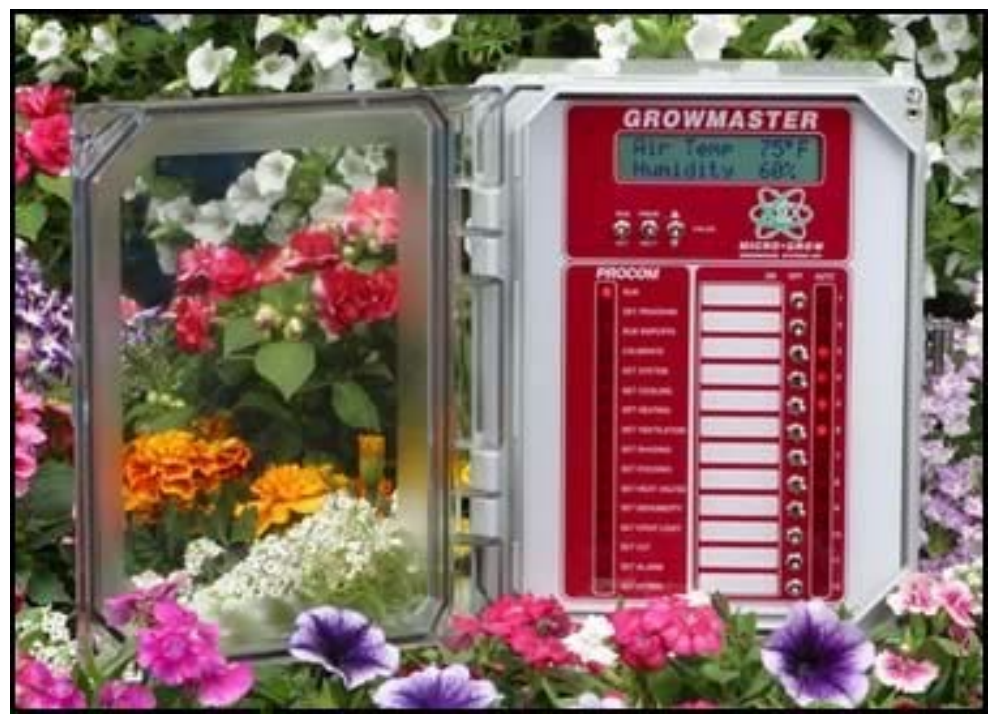

Fonte: Micro Grow (2002)

Figura 13 - Produto Growmaster Procom

O equipamento permite a seleção do controle dos equipamentos de forma automática ou manual. O módulo principal possui quatro entradas digitais, oito entradas analógicas e doze saídas digitais. A sua configuração pode ser redimensionada através da utilização de módulos de expansão. A interligação de vários controladores é possível através de um barramento serial RS-485, e o sistema pode ser interligado a um computador centralizador, localmente ou remotamente (por meio de modems). O preço desse produto no mercado norte-americano, sem incluir nenhum acessório, é de US\$2,395.00. 
O sistema disponibiliza ainda um software dedicado para facilitar a IHM (Interface Homem-Máquina) local ou remotamente, o Growlink, o qual permite a monitoração do processo, alteração dos parâmetros programados, armazenamento e apresentação dos dados do processo. O preço da licença de uso desse software para ambientes operacionais baseados em Windows no mercado norte-americano é de US\$1,595.00.

Como exemplo de equipamento dedicado menos completo e mais simples pode-se citar o produto $\mathrm{CO}_{2}$ Controller da empresa Autogrow Systems Ltd, figura 14. Essa classe de equipamentos possui limitações na quantidade de variáveis e dispositivos controlados; em geral, apenas uma das variáveis ambientais é controlada. Segundo a Autogrow (2002), o produto $\mathrm{CO}_{2}$ Controller permite a injeção de $\mathrm{CO}_{2}$ de maneira pré-programada na casa de vegetação. O controlador possui três estágios de operação:

- Primeiro: Injetando $\mathrm{CO}_{2}$, durante o período pré-programado.

- Segundo: Aguardando enquanto a planta absorve o $\mathrm{CO}_{2}$.

- Terceiro: Ventilando.

O produto possui um sensor de luz que inibe a injeção de $\mathrm{CO}_{2}$ durante a noite ou em períodos escuros. A saída do controlador é baseada em 12 VDC (Voltage Direct Current), que permite a interligação com relés para acionamento de válvulas e ventiladores.

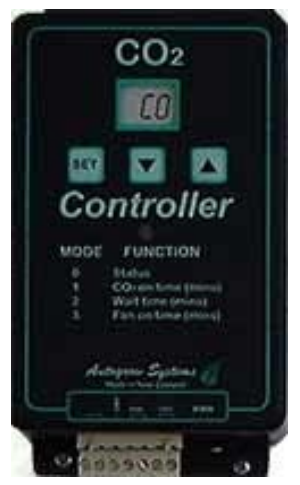

Fonte: Autogrow (2002) 
Há diversos outros produtos e fabricantes de equipamentos de controle e automação dedicados para casas de vegetação no mercado externo. Abaixo são listados alguns desses fabricantes com os seus principais produtos:

- A empresa QCOM Corporation é especializada em equipamentos de controle para irrigação, fertilização e tecnologias de controle ambiental para casa de vegetação. Sua linha é composta por basicamente quatro produtos cobrindo desde necessidades mais simples, como o controle de apenas uma casa de vegetação, até necessidades mais complexas com a interligação de várias casas de vegetação. O produto Growerschoice é um controlador individual, construído em uma caixa de fibra-de-vidro proporcionando robustez em relação ao ambiente de trabalho. O controlador possui relés pilotos, utilizados para acionar contatores, chaves que permitem a intervenção manual e LEDs (Light Emitting Diode) de sinalização para indicação das condições dos relés. O controlador possui também um sensor de temperatura aspirado protegido contra a radiação solar, para evitar leituras errôneas. A configuração dos parâmetros e o acompanhamento das características do sistema podem ser realizados através de um teclado de membrana e um display de cristal líquido. Figura 15.

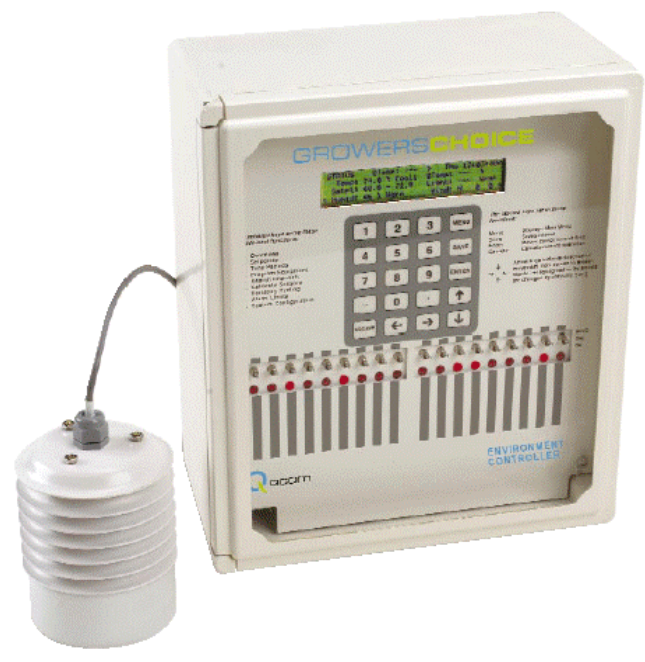

Fonte: QCOM (2003)

Figura 15 - Produto Growerschoice 
Esse produto permite a leitura de temperatura com precisão de $0,1{ }^{\circ} \mathrm{F}$, atualização do display a cada 2 segundos, programação de até quatro períodos diários independentes, controle de lâmpadas HID (High Intensity Discharge) e controle PID (Proporcional-Integral-Derivativo) para válvulas de aquecimento, entre outros. Permite também a interligação via rede com uma estação centralizada para armazenamento de dados e a visualização de gráficos em tempo real e de tendências.

Adicionalmente pode ser incorporado ao sistema um discador automático para notificação remota de alarmes. Uma característica interessante é a possibilidade de sua interligação com dispositivos sem fio como pagers, telefones celulares e PDAs (Personal Digital Assistant), permitindo o gerenciamento da casa de vegetação virtualmente de qualquer local.

- A empresa Wadsworth Control Systems, Inc. possui uma linha de produtos bastante diversificada, variando de controladores na faixa de US\$ 600.00 até US\$ 6,000.00. O produto microSTEP/AS realiza um controle integrado para as funções de aquecimento, resfriamento, umidificação, injeção de $\mathrm{CO}_{2}$, controle de abertura e fechamento de cortinas, irrigação, circulação de ar e iluminação. Esse produto possui 40 saídas que podem ser monitoradas por meio de LEDs, e também chaves manuais para permitir a operação de forma independente do sistema de controle, caso seja necessário.

- A empresa Priva Computers Inc., produz vários equipamentos voltados para o controle de casas de vegetação; entre eles destacam-se os ventiladores, os injetores e monitores de $\mathrm{CO}_{2}$, e computadores de controle de processo. $\mathrm{Na}$ linha de computadores dedicados a empresa possui o Priva Integro e o Priva Maximazer, voltados para o controle de aquecimento e resfriamento, iluminação com lâmpadas HID, sistemas de cortinas e irrigação.

- A empresa Argus Controls comercializa o sistema denominado Argus System. Segundo a empresa, esse é um sistema de controle completamente integrado, possibilitando a utilização de vários tipos e fabricantes de sensores e atuadores, e também a comunicação com um computador remoto através de 
modem. Esse sistema possui ainda um avançado programa de registro de informações, possibilita diversas programações para a monitoração de equipamentos e um sistema de alarme. Um dos principais componentes do sistema é o Argus Controller, que contém o programa de controle e gerencia todas as operações dos equipamentos. Eles podem ser interligados por meio de fio de cobre ou opcionalmente via fibra ótica, nas aplicações em que é necessária a utilização de mais de um controlador. Nessas condições um dos controladores é configurado como mestre e atua como interface para acessos do operador de forma local ou remota. Uma questão interessante é a disponibilidade de suporte telefônico com discagem direta gratuita (toll-free) para o Canadá e Estados Unidos.

- A empresa nacional Fascitec produz equipamentos dedicados ao controle de umidade e temperatura, de condutividade elétrica utilizado na fertirrigação, de irrigação e de aquecimento, entre outros. O controlador de umidade e temperatura MFC $\mathrm{CH}$ controla essas variáveis através de 2 saídas para aquecedores e 2 saídas para ventiladores.

- E finalmente, a empresa Remote Measuremente Systems comercializa o software ADControl baseado em placas de aquisição de dados e voltado para computadores da linha Macintosh.

Essa pequena relação de fornecedores de produtos dedicados para automação de casas de vegetação não esgota o universo desses fabricantes.

Algumas observações importantes devem ser destacadas:

- Embora existam empresas com soluções altamente integradas e complexas, existe um número considerável de empresas com soluções simples, controlando apenas uma das funções existentes na casa de vegetação como, por exemplo, sistema para controle de ventilação, sistema para controle de iluminação e sistema para controle de injeção de $\mathrm{CO}_{2}$, entre outros.

- Pela análise dos diversos fornecedores de tecnologia dedicada a casas de vegetação, constata-se que os sistemas são fechados, ou seja, proprietários, 
tornando praticamente impossível a interligação de sistemas de fabricantes diferentes.

- Esses fabricantes, na sua maioria situados no hemisfério norte, estão distantes da realidade nacional, não só na questão econômica como também climatológica. No hemisfério norte a preocupação é com o clima frio e com a baixa radiação luminosa, enquanto no Brasil predomina o clima quente e a alta radiação luminosa. Essas diferenças, muitas vezes, não são levadas em conta na elaboração desses produtos.

\subsubsection{Equipamento de propósito geral}

O controle de ambientes pode ser realizado com base em outras soluções de mercado, através da utilização de equipamentos e softwares de propósito geral usualmente utilizados em automação industrial. Entre esses equipamentos, destacamse os CLPs e as placas de aquisição de dados. Figura 16.
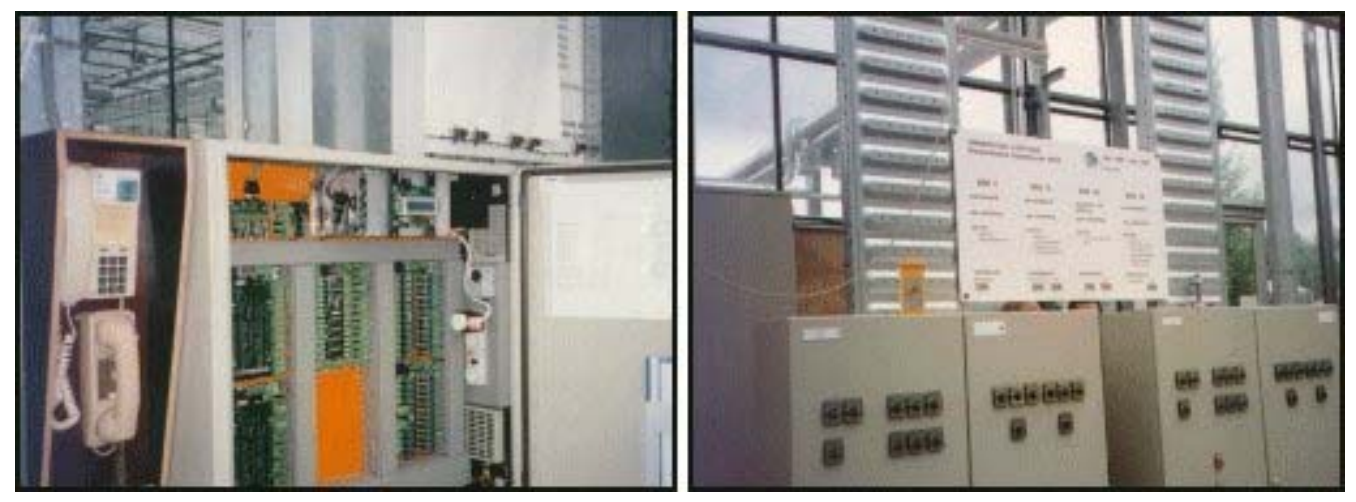

Foto: Prof. Dr. Antonio Mauro Saraiva

Figura 16 - Armário de CLP utilizado na automação de uma casa de vegetação em Wageningen, Holanda

- Segundo Simpson (1994), o CLP foi desenvolvido através da especificação de 6 critérios por engenheiros da empresa General Motors (Hydramatic division) em 1968. Os critérios são: 
1. O dispositivo deve ser facilmente programado, possibilitar a alteração do programa de forma rápida e preferencialmente na planta.

2. O dispositivo deve possuir uma manutenção simples e, caso necessite de reparo, que seja feito na forma de montagem por conector (Plug-in), permitindo pronta substituição.

3. O dispositivo deve operar em ambiente fabril, com uma confiabilidade maior do que os painéis de controle.

4. O dispositivo deve ser fisicamente menor do que painéis de controle por relé, para economizar no alto custo de espaço nas indústrias.

5. O dispositivo deve possuir a capacidade de enviar dados para um sistema central de coleta de dados.

6. O dispositivo deve ser competitivo em custo com painéis baseados em relés ou transistores.

Desde a época de sua especificação, até os dias atuais, os CLPs vêm sofrendo aprimoramentos sucessivos e cada vez mais se aproximando das especificações originais. Pelos critérios listados acima se verifica que os CLPs foram originalmente projetados para serem utilizados em automação industrial, possuindo, portanto, diversas vantagens para sua utilização em casas de vegetação em contraste com painéis de controle por lógica de relés tradicionais. Entre essas vantagens estão: versatilidade de mudança nos programas de controle; facilidade de instalação e programação; velocidade de operação dos temporizadores internos; possuem restrição de acesso por hardware (hard-key) e por software (password); solução de problemas de forma mais simples; possuem capacidade de comunicação com computadores locais e remotos; por serem modulares permitem a expansão do sistema de uma forma natural; e, por fim, eles são elementos de controle extremamente confiáveis para trabalho em ambientes agressivos. 
Os CLPs podem ter entradas digitais e analógicas, permitindo a interligação tanto com sensores que fornecem sinais discretos no tempo como sensores que fornecem sinais analógicos. De forma similar, eles possuem saídas digitais e analógicas, permitindo o controle de equipamentos com controle discreto, do tipo liga-desliga, bem como de equipamentos com controle proporcional. Os estágios de entrada e saída do CLP possuem isolamento entre os sinais de controle e a unidade central de processamento, aumentando sua robustez e confiabilidade.

Os CLPs possuem uma capacidade de memória modular, o que permite a expansão da complexidade dos algoritmos de controle, caso seja necessário, e também possuem velocidades de operações diferentes, permitindo a opção de escolha do modelo mais apropriado para a execução de determinada tarefa.

Um fator que com certeza limita a utilização desse dispositivo para automação agrícola é seu custo, considerado elevado para nossa realidade. Apenas para referência, um dos modelos mais simples de CLP é o modelo FP0-C16T. Esse dispositivo é da empresa Aromat, subsidiária do conglomerado Matsushita, e custa em torno de US\$ 500.00, possuindo apenas oito entradas digitais e oito saídas digitais.

\subsubsection{Algumas considerações sobre o mercado nacional}

$\mathrm{Na}$ elaboração do presente trabalho realizou-se um estudo sobre a situação da automação disponível do mercado nacional para ser utilizada em casas de vegetação. Esse estudo foi baseado em visitas a feiras, contatos com fabricantes de casas de vegetação e agricultores.

As feiras que tratam mais especificamente sobre cultivo protegido são a Hortitec e a Agrishow, que ocorrem anualmente em Holambra e Jundiaí, no interior de São Paulo.

Na Hortitec 2001 foi possível verificar as poucas ofertas voltadas especificamente para a automação, sendo alguns casos a exposição apenas dos equipamentos atuadores e sensores independentes, por exemplo, fornecedores de bombas para 
irrigação, condutivímetros, medidores de temperatura, medidores de PH, sistemas de aquecimento e/ou resfriamento e telas de sombreamento, entre outros.

$\mathrm{Na}$ Hortitec 2003 verificou-se um número maior de empresas com produtos específicos para automação. A empresa Tropclima, fornecedora de equipamentos para casa de vegetação, possui uma linha de produtos considerável, fornecendo aquecedores de ar, caldeiras, exaustores laterais, painéis evaporativos e sistemas de umidificação. A Tropclima comercializa o sistema denominado "computador de clima", da empresa canadense Priva Computers Inc. A empresa Fascitec expôs uma linha de controladores agrícolas com tecnologia própria, destacando se os controladores de EC (Electrical Conductivity), $\mathrm{pH}$, umidade, temperatura e sombreamento. E finalmente, a empresa Hydrosystem comercializa uma linha de produtos destinados a irrigação.

No Agrishow 2001 foram feitos contatos com fabricantes de casas de vegetação para levantamento da linha de produto desses fabricantes, conhecimento da realidade nacional e experiências obtidas no uso de automação. As seguintes considerações foram levantadas na Agrishow:

- A empresa Dynacs Estufa Agrícola é um exemplo de empresa cujos produtos não incorporam nenhum tipo de automação, e que comercializa um sistema de sombreamento interno acionado manualmente e controlado por chaves de fim de curso. O proprietário dessa empresa, o Sr. Fabio Y. Okino, comentou que quando é necessário algum tipo de automação, ela é realizada através da montagem um circuito elétrico baseado em relés. Uma observação importante foi referente ao custo dessa automação comparativa ao custo da casa de vegetação. O custo do metro quadrado era de R\$10,00 (Junho/2001) e o preço da automação básica utilizando um relé da Siemens estava em torno de R \$ 2.000,00, evidenciando a preocupação com o custo da automação. Por fim observou que as principais regiões de consumo de estufas estão em São Paulo, mais especificamente em Ibiúna, Vargem Grande Paulista e Holambra, entre outras. 
- O Eng ${ }^{\circ}$ Carlos Orlandi, diretor da empresa Hidrogood Hidroponia Moderna, comentou que:

- Praticamente inexiste automação em hidroponia no Brasil e em função disso existe um vasto campo para a automação, citando como exemplo, o controle da solução nutritiva em circuito fechado, utilizando sensores de $\mathrm{pH}$ e condutivímetro. $\mathrm{O}$ sistema de automação deveria ser algo simples e barato, pois o agricultor tem muitos custos e não iria conseguir pagar por equipamentos sofisticados, sendo que essa sofisticação deveria ser incorporada com o tempo, na medida em que o agricultor fosse criando confiança na tecnologia.

- Observou uma forte automação em visita realizada em Almeria, na Espanha, e recomendou contatos com os formadores de opinião na área, principalmente os pesquisadores do IAC (Instituto Agronômico), entre eles o professor Pedro Furlani e Flávio Fernandes.

- O Sr. Carlos A. Franciosi, diretor técnico da empresa Agriestufa Indústria e Comércio Ltda, comentou que:

○ O custo da automação é fundamental, sendo o principal parâmetro para sua utilização, e que o consumidor prefere pagar um valor reduzido por um controlador com apenas três funções do que três vezes esse valor por um controlador com 20 funções.

- A qualidade da energia elétrica fornecida no campo pode comprometer a viabilidade da utilização de placas de circuitos eletrônicos, citando como exemplo um cliente que desistiu de usar placa de computador importada após a ocorrência da segunda queima. Essa experiência alertou para a necessidade da existência de redundância, possibilitando o controle manual dos equipamentos no caso de falha do controlador.

- Existe mercado para automação, porém seu crescimento é muito lento, sendo que os dispositivos de automação utilizados são de origem 
européia e não condizem com nossa realidade e que está experimentando trazer os dispositivos de Israel.

- Os clientes da Hidrogood utilizam casas de vegetação principalmente para a produção de folhagens, ficando flores e frutas com um porcentual menor.

- O Sr. Erasmo Prioste, engenheiro de vendas da empresa Van der Hoeven Estufas Agrícolas, comentou que:

- A linha de produtos da empresa Van der Hoeven possui vários tipos de automação e que existem alguns fabricantes nacionais de equipamentos para automação industrial iniciando um trabalho voltado para de casas de vegetação, citando como exemplo a empresa Fascitec Controladores Eletrônicos, que possui produtos para automação de cortinas, temperatura, umidade relativa e luminosidade.

- Existe demanda para automação e o discurso para a comercialização deve ser sobre produtividade, exemplificando que os clientes que investem R\$ 100.000,00 em uma casa de vegetação não se importariam em desembolsar mais $10 \%$ ou $20 \%$ em automação, desde que seja demonstrado o ganho de produtividade.

○ Praticamente não existe automação para o clima tropical, e que os controladores disponíveis são de origem européia, onde a questão do aquecimento é mais importante que o resfriamento, sendo que nossa necessidade é o contrário, ou seja, o resfriamento. Na Holanda o controle de luminosidade é importante no sentido de suprir a deficiência luminosa, sendo questionável no Brasil, onde o controle, quando realizado, tem a característica de redução dessa luminosidade. A utilização de dispositivos importados leva a uma questão crítica que é a disponibilidade de assistência técnica para suportar eventuais falhas. Existe automação utilizando pequenas estações meteorológicas para operar abertura e fechamento de janelas (laterais ou zenitais) por 
meio da medição da velocidade e direção do vento e também da existência ou não de precipitação de chuva.

- Em relação ao desenvolvimento de automação para casas de vegetação o aspecto funcional é o mais importante, devendo ter a princípio funções simples, de baixo custo e a possibilidade de posterior expansão e sofisticação.

○ Em relação ao mercado de casas de vegetação, São Paulo é o principal consumidor, e que existem clientes eventuais na BA, MT, AM, RS e MG, entre outros.

A visita a um tradicional fabricante nacional de casas de vegetação, a Van der Hoeven, foi importante para a aquisição de conhecimentos dos tipos de casas de vegetação que eram comercializadas, do grau de automação desses produtos e das oportunidades de aplicações que necessitavam automação.

- A empresa, localizada em Holambra, foi fundada em função da necessidade da região em produzir flores, principalmente para o mercado externo, com um grau elevado de controle dessa produção. A empresa possui uma linha de produtos extremamente robusta, sendo que sua longevidade, segundo a empresa, é de aproximadamente 20 anos. As estruturas de seus produtos são fabricadas com ferros galvanizados na própria fábrica.

- Em relação ao grau de automação pôde-se constatar que poucos clientes solicitavam algum grau de automação, sendo que esta era feita através de um quadro de comandos tradicional. Esses quadros implementam uma lógica por meio de relés, utilizando termostatos para o controle de temperatura e, em situações especiais, utilizavam higrômetros para o controle de umidade. $\mathrm{O}$ controle de iluminação pode ser realizado através de timer. Devido a lógica de controle ser realizada por meio de relés, todos os sensores e atuadores utilizados eram do tipo digital, ou seja, apresentavam saída e/ou entrada do tipo ligada ou desligada. 
- Foram observadas três oportunidades de aplicação da automação para ambiente protegido: controle do nível de umidade em resíduos de esgotos, controle da umidade em castanha de caju e controle da abertura e fechamento do teto na geração e criação de matrizes, por exemplo, pinheiros.

A participação no "II Seminário Internacional de Cultivo Protegido em Hortaliças, Flores e Mudas Cítricas" auxiliou na criação de uma visão mais geral de toda a cadeia envolvida nessa técnica de produção agrícola e propiciou a observação da preocupação do desenvolvimento sustentado do cultivo protegido no Brasil em todos os estágios envolvidos, sendo abordadas questões como a importância do manejo climático em casas de vegetação, a utilização da fertirrigação em cultivo protegido, o controle de pragas e doenças em cultivo protegido, o comércio eletrônico, o cultivo com hidroponia e as tendências e oportunidades da agricultura orgânica.

\subsection{Sensores/Transdutores}

Segundo Sinclair (1995), um sensor é um dispositivo que detecta ou mede uma quantidade física e o transdutor é um dispositivo que converte uma forma de energia em outra. A diferença entre ambos é muito tênue, pois o sensor realiza a ação de conversão de energia e o transdutor deve necessariamente sentir alguma quantidade física. A mínima diferença encontra-se na eficiência da conversão de energia. $O$ principal propósito do sensor é detectar e medir, não sendo importante se sua eficiência de conversão de energia é de $5 \%$ ou $0,1 \%$. O transdutor, ao contrário, é planejado para converter energia e sua eficiência é importante, ainda que em certos casos essa eficiência possa não ser muito alta. Uma outra diferença básica está na linearidade da resposta, importante para os sensores e menos significante para os transdutores. Já para Bradley (1991), em um sistema de medição, os sensores e transdutores são utilizados para fornecerem informações sobre as condições do sistema sob observação. Infelizmente, a utilização dos termos 'sensor' e 'transdutor' é complicada por uma variedade de diferentes significados adotados internacionalmente, sendo que em alguns momentos possuem uma aparente permutabilidade. Segundo o autor, um sensor é a parte do sistema de medida que responde à variação da grandeza física a ser medida. Um transdutor é o componente do sistema que transfere informação em uma forma de energia de uma parte do 
sistema para outra, inclusive, em alguns casos chegando a alterar a forma de energia que contém a informação. Em função da utilização da energia os transdutores podem ser classificados como:

- Diretos ou passivos, não necessitando de fonte de energia além daquela fornecida pela variável monitorada. Exemplo: dispositivos fotoelétricos e termopares, entre outros.

- Indiretos ou ativos, quando é necessário o fornecimento de energia adicional. Exemplos: Extensômetros (strain gauges) e dispositivos baseados em efeito Hall, entre outros.

Do exposto acima se verifica que a correta utilização dos termos sensor e transdutor não é trivial e sua abordagem não é o objeto principal do presente trabalho. Para o presente trabalho será utilizado o termo sensor para o dispositivo utilizado na medição da variável física. Sendo assim, os sensores de interesse são os elementos que convertem alterações de parâmetro físico em sinais elétricos, sendo que suas saídas podem ser expressas em termos de tensão, resistência e corrente.

Para a monitoração do clima no interior e no exterior de uma casa de vegetação são utilizados diversos tipos de sensores, classificados em função da variável física monitorada, e descritos a seguir.

\subsubsection{Medida de temperatura}

A temperatura é uma medida numérica do nível de energia térmica de um corpo, ou seja, o quanto quente ou frio está esse corpo. Devido a essa característica, várias escalas são utilizadas para medir a temperatura; as principais são a de graus Celsius $\left({ }^{\circ} \mathrm{C}\right)$ e a de graus Kelvin $(\mathrm{K})$, (os pontos de congelamento e ebulição da água pura servem como referência para a medição). A medição da temperatura em casas de vegetação de uma maneira simples e econômica pode ser realizada através das seguintes tecnologias:

- RTD (Resistance Temperature Detector) - Esses sensores são baseados no princípio do aumento da resistência elétrica do condutor com o aumento da 
temperatura. $\mathrm{O}$ condutor geralmente utilizado é a platina, pois esta apresenta características especiais, como precisão e estabilidade para uma grande faixa de temperatura. É quimicamente inerte e pode ser utilizado em altas temperaturas. Um sensor bastante popular é o Pt 100, que representa um RTD baseado em condutor de platina com resistência de $100 \mathrm{Ohms}$ a $0{ }^{\circ} \mathrm{C}$. Figura 17.

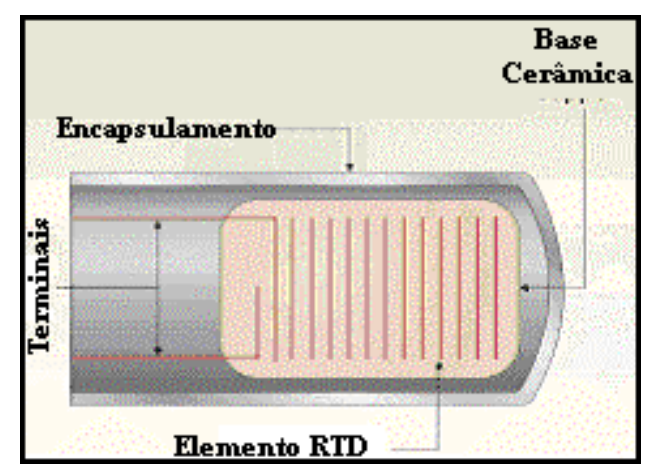

Fonte: Mathews (2003)

Figura 17 - Sensor de temperatura - RTD

- Circuitos integrados - Transdutores de temperatura. São circuitos eletrônicos integrados, baseados em semicondutores, construídos de maneira adequada, que apresentam a corrente de saída proporcional à temperatura absoluta. $\mathrm{O}$ componente AD590 permite o fluxo de 1 microampére para cada grau Kelvin.

- Termistores - São elementos que apresentam alterações na sua resistência elétrica em função da temperatura. Segundo Trietley (1986), são utilizadas duas classes de matérias para sua construção: os óxidos de metais e o silício. Os termistores podem ser classificados em dois tipos: os de resistência negativa, conhecidos como NTC (Negative Temperature Coefficient), nos quais a resistência elétrica diminui com o aumento da temperatura, e os de resistência positiva, conhecidos como PTC (Positive Temperature Coefficient), nos quais a resistência elétrica aumenta com o aumento da temperatura. Figura 18. 


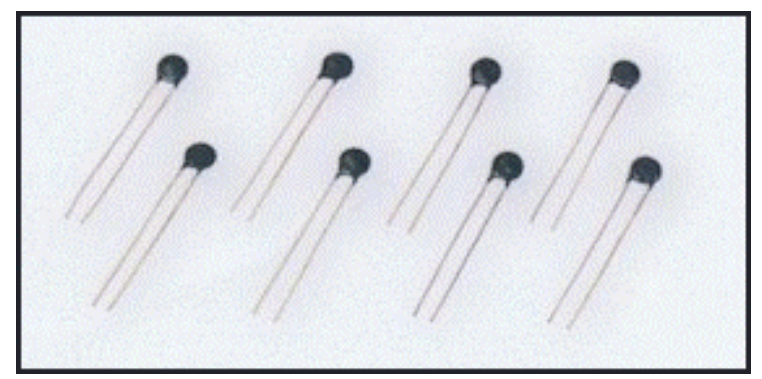

Fonte: Tecway (2003)

Figura 18 - Sensor de temperatura - Termistor

\subsubsection{Medida de umidade}

Uma forma de se expressar umidade é através da "umidade relativa" que é a taxa, em porcentagem $(\%)$, da quantidade de vapor d'água no ar, em relação à quantidade de vapor d'água no ar saturado na mesma temperatura e pressão. A umidade relativa é fortemente afetada por alterações na temperatura. Segundo a empresa RMS (Remote Measurement Systems) (2002), o sensor de umidade mede apenas uma camada de vapor d'água que está em contato com ele, portanto deve ser instalado em local onde exista uma amostra razoável da atmosfera a ser medida. Outras recomendações são que haja uma boa circulação de ar e também que o sensor não seja atingido diretamente por água no estado líquido.

A medição da umidade pode ser realizada através das seguintes tecnologias:

- Higrômetro de cabelo - Segundo Rodríguez e Berenguel (2002), essa tecnologia se baseia no princípio físico que determinados tecidos animais apresentam de variar sua elasticidade com a umidade. Um higrômetro pode ser construído com um feixe de fios de cabelo tensionado por uma mola ligada ao cursor de um potenciômetro. Através da medição da resistência entre o cursor e uma das extremidades do potenciômetro correlaciona-se a umidade.

- Sensores capacitivos - Baseiam-se no princípio físico da variação das características elétricas do dielétrico de um capacitor em função da umidade. Esses sensores são particularmente interessantes para medição de umidade 
entre aproximadamente 10 e $90 \%$ pois em umidades maiores o dielétrico se satura e necessita de um tempo maior para estar disponível para novas medições. Deve-se observar para que não ocorra saturação, ou seja, contato do sensor com água no estado líquido, pois além de fornecer medidas incorretas, pode danificar o sensor. Figura 19.

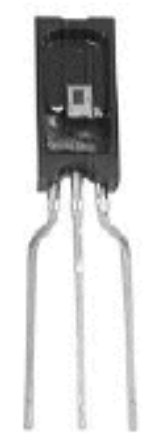

Fonte: Honeywell (2003)

Figura 19 - Sensor de umidade capacitivo

\subsubsection{Medida de radiação luminosa}

Devido à característica ondulatória da luz, existem sensores baseados em intensidade e outros em freqüência. Tendo em vista que a luz solar é composta de um largo espectro de freqüência, o qual pode ser dividido em diversas regiões, cada qual caracterizada por suas faixas de freqüências. Segundo Priva-b (2002), os sensores podem ser classificados como:

- Lineares - São bastante populares devido ao seu baixo custo. Esses sensores detectam a luz de forma similar ao olho humano, cuja resposta varia diretamente com alterações na intensidade da luz. Sensores desse tipo apenas fornecem uma indicação grosseira da intensidade da luz.

- $\mathrm{PAR}$ - Esses sensores detectam variações da energia da luz na faixa entre 400 até $700 \mathrm{~nm}$, utilizada pela planta para realizar fotossíntese. 
- Solares - Também conhecidos como sensores de radiação global ou pirômetros. Esses sensores medem a energia recebida num espectro largo de freqüência, inclusive a faixa de luz visível. Eles apresentam a vantagem de uma melhor precisão, especialmente em condições de baixa luminosidade. Figura 20.

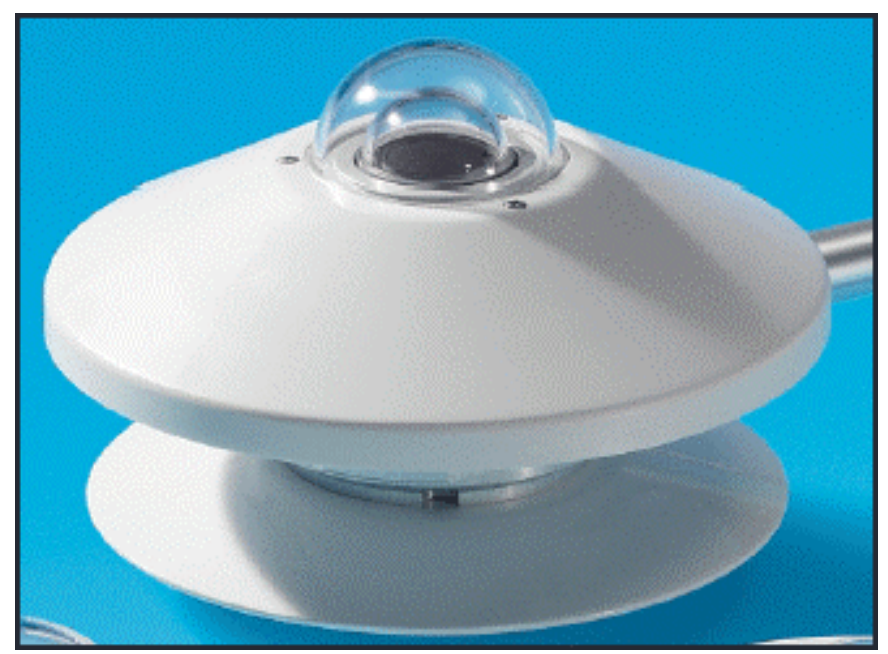

Fonte: Delta Ohm (2003)

Figura 20 - Sensor de radiação solar

A radiação luminosa pode ser expressa, entre outras formas, em Watts por metro quadrado $\left(\mathrm{W} / \mathrm{m}^{2}\right)$, em fótons ou em lumens.

\subsubsection{Medida de concentração de $\mathrm{CO}_{2}$}

A concentração de $\mathrm{CO}_{2}$ na atmosfera é uma grandeza relativamente difícil de ser medida. Geralmente os sensores se baseiam na capacidade de absorção da radiação infravermelha do $\mathrm{CO}_{2}$. A medição é feita pela passagem do ar por uma câmara na qual existem um emissor e um receptor de radiação infravermelha. Devido à complexidade óptica do emissor e receptor, bem como da eletrônica fina associada, a medição da concentração de $\mathrm{CO}_{2}$ não é trivial. É geralmente expressa em ppm. Figura 21. 


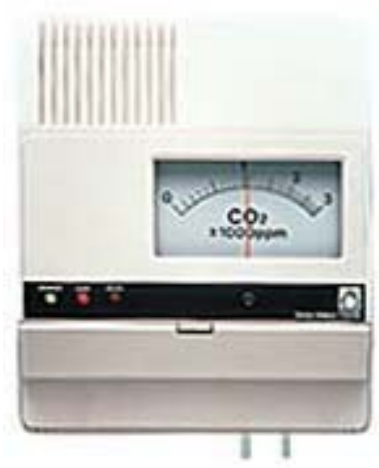

Fonte: Priva-a (2003)

Figura 21 - Sensor de dióxido de carbono - $\mathrm{CO}_{2}$

\subsubsection{Medida de velocidade do vento}

A velocidade do fluxo de ar pode ser medida por uma grande variedade de instrumentos. Eles podem ser resumidos em três grandes grupos baseados em princípios mecânicos, princípios térmicos ou ultra-som. A unidade de medida normalmente utilizada é metros por segundo $(\mathrm{m} / \mathrm{s})$.

- Anemômetros mecânicos - São dispositivos que possuem uma haste giratória cuja rotação é proporcional à velocidade do vento. Existem basicamente duas formas de converter a grandeza mecânica (giro) em grandeza elétrica, sendo a primeira através de um dínamo e a segunda através de codificadores incrementais. O dínamo tem a propriedade de gerar uma tensão elétrica proporcional à rotação de seu eixo. Os codificadores incrementais produzem um determinado número de pulsos elétricos por rotação. Através da contagem do número de pulsos ocorridos em um determinado intervalo de tempo se calcula a velocidade do vento. Figura 22. 


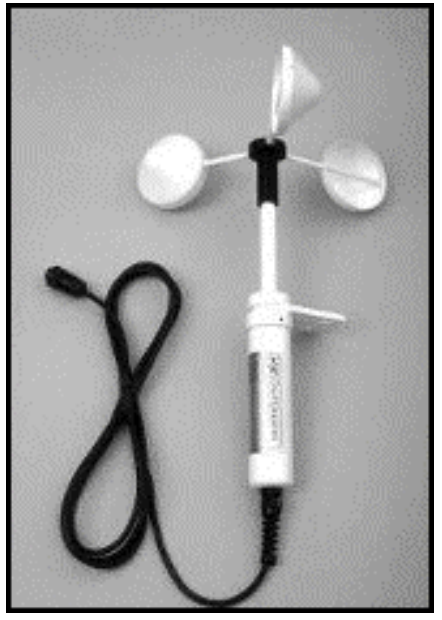

Fonte: Environdata-a (2003)

\section{Figura 22 - Sensor de velocidade do vento}

- Anemômetros de fio quente - São dispositivos baseados no princípio da transferência de calor de um condutor, mantido a temperatura constante, para o fluido com o qual está em contato. A transferência de calor é relacionada com a velocidade do fluido e com sua temperatura. Através da utilização de um fio condutor, cuja resistência elétrica varie consideravelmente com a temperatura na faixa de velocidade desejada, pode-se medir a velocidade do ar submetendo-se esse condutor ao fluxo de ar. $O$ fio se resfriará proporcionalmente à quantidade de ar que circulou pela unidade de tempo, alterando sua resistência. Para se manter o equilíbrio térmico com a temperatura do condutor constante é necessário se alterar a potência fornecida ao condutor. Essa potência é função da temperatura ambiente e da velocidade do fluido. Uma característica interessante desse dispositivo é a possibilidade de se medirem fluxos de baixa intensidade, geralmente comuns no interior das casas de vegetação.

- Anemômetros de ultra-som - São dispositivos baseados no princípio da emissão e recepção de ultra-som. O tempo de propagação do ultra-som é proporcional à velocidade do vento. 


\subsubsection{Medida de direção do vento}

Similarmente à velocidade do vento, a medida da direção do vento pode ser feita de várias formas. Elas podem ser resumidas em dois grandes grupos: as baseadas em princípios mecânicos e em ultra-som.

- Medidores mecânicos - São baseados em um braço que gira sobre um eixo vertical ao qual se adiciona uma aleta com uma área e peso apropriados, no sentido de que a aleta fique livre para se orientar paralelamente ao fluxo de ar. Existem basicamente duas formas de converter a grandeza mecânica (posição) em grandeza elétrica: os potenciômetros e os codificadores absolutos. Os medidores baseados em potenciômetros têm sua resistência elétrica variando em função da posição do eixo da aleta. Os codificadores absolutos apresentam um sinal de saída codificado proporcionalmente à posição da aleta em relação a uma referência interna. Figura 23.

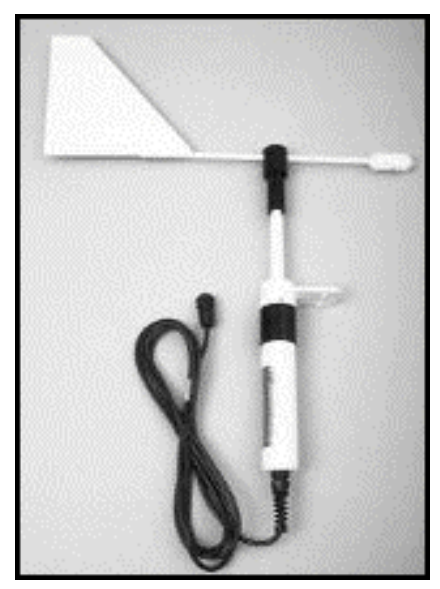

Fonte: Environdata-b (2003)

Figura 23 - Sensor de direção do vento

- Medidores ultra-sônicos - Estes dispositivos apresentam três pares de emissores e receptores de ultra-som com posicionamento pré-definido. $\mathrm{O}$ tempo de propagação do ultra-som é proporcional à direção do vento. 


\subsubsection{Medida de chuva}

Devido às características intrínsecas do cultivo protegido, existe a necessidade de se fecharem as janelas laterais ou zenitais quando da ocorrência de chuva, sendo necessária, portanto, apenas a informação da presença ou da ausência de chuva, não sendo relevante a quantidade, exceto para fins do controle do manejo de água fora da casa de vegetação. A chuva pode ser detectada através das seguintes técnicas:

- TBR (Tipping Bucket Raingauge) - Nessa técnica a chuva é capturada por um coletor de aproximadamente $200 \mathrm{~mm}$ de diâmetro de abertura, o qual recolhe a chuva e a encaminha para um sistema de básculas alternadas, que é constituído de uma haste apoiada ao centro com reservatórios (conchas) nas extremidades, formando uma espécie de gangorra. Esse sistema permite o enchimento de um reservatório por vez. Quando o primeiro está cheio, por efeito de gravidade, ele desce, fazendo com que o segundo suba e passe a receber o fluxo de chuva. Durante a descida ele se esvazia e aciona um relé magnético ou um "reed switch", gerando um pulso na saída. Medindo-se o tempo entre pulsos e conhecendo-se a capacidade do reservatório é possível calcular a intensidade e a quantidade de precipitação de chuva. Figura 24.

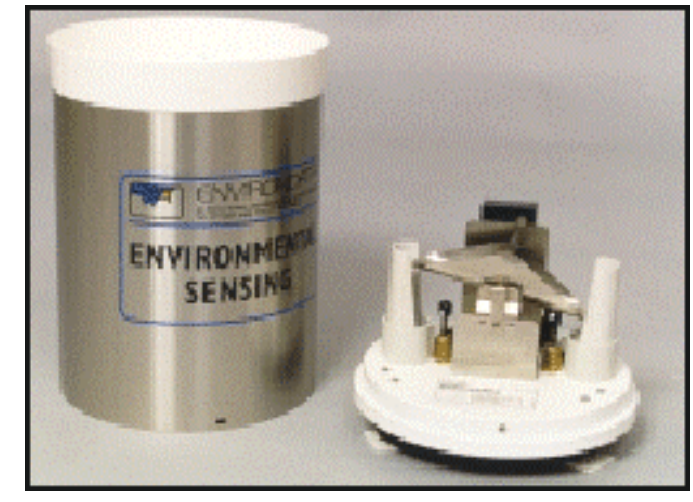

Fonte: Environdata-c (2003)

Figura 24 - Sensor de intensidade de chuva tipo TBR 
- Condutividade - Os sensores baseados nesse princípio apresentam eletrodos que, quando em contato com a água, têm sua condutividade alterada, indicando assim a presença de chuva.

\subsection{Atuadores}

Segundo Rodríguez e Berenguel (2002), os atuadores são equipamentos que permitem, através de controle adequado, manter as variáveis climáticas da casa de vegetação dentro dos limites desejáveis. Existem quantidades razoáveis de equipamentos disponíveis para esse objetivo, sendo uma forma prática classificá-los através das funções que eles desempenham.

\subsubsection{Ventilação}

Segundo Infoagro-b (2002), a melhor maneira de se classificar o tipo de ventilação é através da forma como se realiza a renovação do ar do interior da casa de vegetação. A ventilação pode ser classificada como:

- Natural ou passiva - Esse tipo de ventilação é proporcionada através da colocação de janelas na estrutura da casa de vegetação, de maneira que possa haver uma troca de ar naturalmente entre o interior e o exterior. Vide figura 25. Essas janelas são providas por estruturas que possibilitam sua abertura ou fechamento, podendo isso ser feito manual ou automaticamente através de motores. Existem basicamente dois tipos de janelas de ventilação natural: lateral e de teto, sendo que a de teto é mais conhecida como "Zenital" e possui relativamente um rendimento maior, pois o ar quente dentro da casa de vegetação tende a se acumular no teto. Algumas dessas janelas são automatizadas com motores elétricos e chaves de fim de curso, permitindo que se faça a abertura de forma proporcional, ou por controle do tempo de ativação ou por chaves colocadas em posições pré-definidas. 


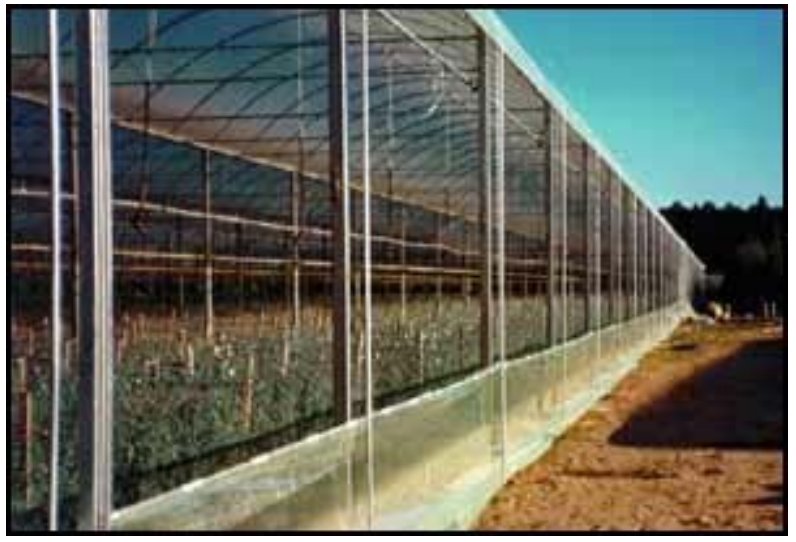

Fonte: Agrinther-b (2003)

Figura 25 - Janela lateral

- Forçada ou ativa - Esse tipo de ventilação é realizada através de ventiladores elétricos, os quais proporcionam uma taxa de troca de ar mais elevada do que da forma natural. Em geral os ventiladores possuem venezianas que permanecem fechadas enquanto ele estiver desligado, evitando a entrada de insetos na casa de vegetação. Vide figura 26. Existem ventiladores que podem ser acionados de forma variável, permitindo um melhor controle da taxa de troca de ar.
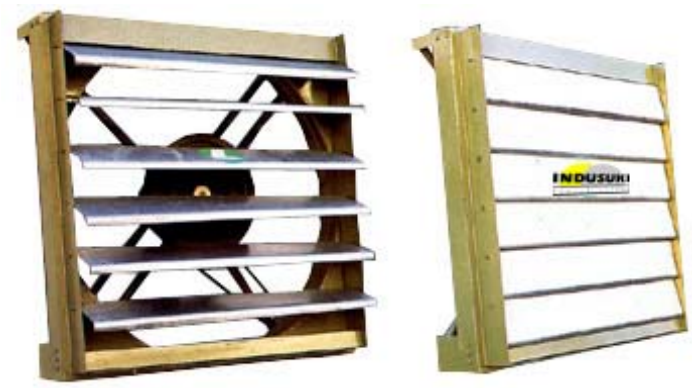

Fonte: Indusuki (2003)

Figura 26 - Ventilador com veneziana de proteção

\subsubsection{Aquecimento}

A utilização de sistemas de aquecimento é uma característica mais peculiar de regiões nas quais a temperatura cai a níveis prejudiciais à cultura, não sendo a principal preocupação nos climas tropicais. Apenas a título de comentário, existem 
várias técnicas de promover o aquecimento do ar no interior da casa de vegetação, destacando-se a utilização de vapor d'água, encanamento com água quente (caldeiras) e por meio de combustão de hidrocarbonetos, entre outros.

\subsubsection{Umidificação e resfriamento}

Existem basicamente dois tipos de sistema de umidificação e resfriamento:

- Paredes evaporativas - Também conhecido pelo termo Inglês "pad-fan". De acordo com Infoagro-b (2002), esse sistema se baseia no princípio de forçar a passagem de uma corrente de ar através de uma parede permeável (à corrente de ar) constantemente umedecida. Essa parede pode ser feita de papelão, fibra de madeira e em alguns casos com pedregulhos ou argila expandida. Quando a corrente de ar atravessa essa parede ela se esfria e se impregna de umidade. A corrente de ar é criada através da instalação de ventiladores na parede oposta à parede umedecida. Os equipamentos envolvidos nesse sistema são: bombas elevadoras d'água e ventiladores. Dependendo da distância entre as paredes, pode-se criar uma zona de diferença climática, pois em geral a temperatura e umidade nas proximidades da parede umidecida são diferentes da temperatura e umidade nas proximidades da parede na qual estão instalados os ventiladores. A figura 27 é um exemplo de parede evaporativa.

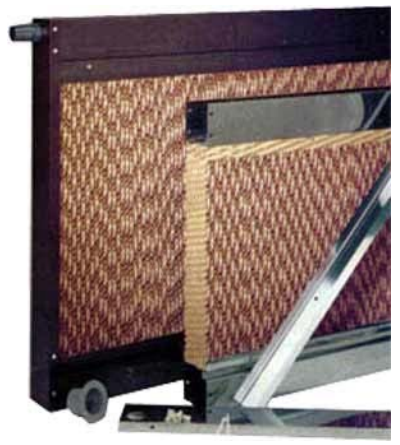

Fonte: Agrinther-c (2003)

\section{Figura 27 - Parede evaporativa}

- Nebulizadores - Também conhecido pelos termos ingleses "Fog System" ou "Mist". O sistema consiste em se produzir periodicamente uma névoa ou 
nevoeiro dentro da casa de vegetação. Através da utilização de bombas de alta pressão, bicos aspersores especiais com orifícios de precisão feitos a laser e ventiladores, é possível a criação artificial desse nevoeiro. Figura 28. Segundo o ITE (Instituto Tecnológico Europeo) (2002), o diâmetro da gota produzida é de fundamental importância, pois gotas com diâmetros acima de 50 micras, por gravidade atingem o solo ou as culturas em curto espaço de tempo, chegando a molhá-las. Sendo assim, recomendada-se a utilização de gotas com diâmetro em torno de 10 micras, pois elas tendem a flutuar não encharcando as culturas, portanto, não criando ambiente propício ao desenvolvimento de doenças. Uma vantagem desse sistema é a possibilidade de homogeneização da temperatura e umidade em todo o ambiente da casa de vegetação.

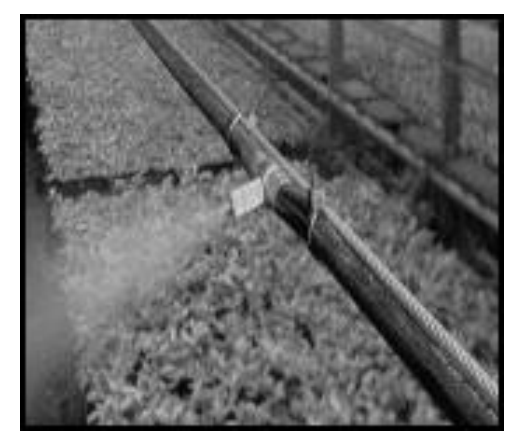

Fonte: ITE (2002)

\section{Figura 28 - Bico aspersor}

\subsubsection{Radiação luminosa}

O controle de radiação luminosa pode ser feito de diversas maneiras. A idéia principal é limitar a passagem de raios solares para o interior da casa de vegetação em dias com alta radiação ou aumentar a radiação no interior da casa de vegetação em períodos de pouca luz, para culturas que apresentam um desenvolvimento otimizado com controle do fotoperíodo. Alguns exemplos de sistema de controle de radiação luminosa são:

- Malhas de sombreamento - Sistema utilizado para diminuir a radiação no interior da casa de vegetação. Consiste de uma malha, em geral de tecido, que 
pode ser estendida ou recolhida sobre a cultura, limitando a passagem da radiação. Figura 29. Existe uma grande gama de coberturas com variadas porcentagens de transmissão, reflexão e porosidade, e a escolha depende da necessidade de cada cultura. A extensão, bem como o recolhimento da malha, podem ser feitas de forma manual ou automática, através de motores elétricos. As malhas podem ser instaladas interna ou externamente à casa de vegetação, sendo que internamente sua eficiência é menor que externamente, porém com uma durabilidade maior. A instalação externa, além de controlar a radiação, proporciona uma temperatura mais amena no interior da casa de vegetação.

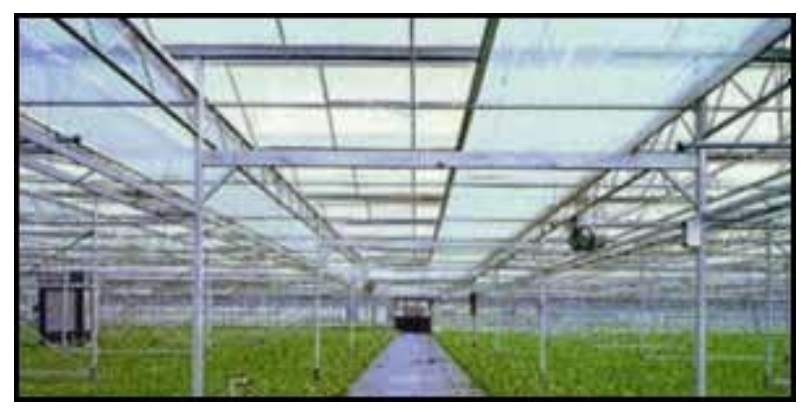

Fonte: Agrinther-d (2003)

\section{Figura 29 - Sistema de sombreamento interno}

- Pintura externa - Uma outra forma de diminuir a radiação no interior da casa de vegetação é através da pintura do teto com cal. Esse método não é indicado por não proporcionar qualquer controle, além de poder atacar quimicamente o plástico da cobertura e ser de difícil remoção.

- Iluminação artificial - Utilizada para aumentar a radiação luminosa no interior da casa de vegetação ou para estender o número de horas sob iluminação, visando otimizar o fotoperíodo. Pode ser realizada através da utilização dos seguintes tipos de lâmpadas: incandescentes, vapor de mercúrio, mistas e fluorescentes. Cada tipo tem suas características peculiares que são mais ou menos indicadas em função do consumo de energia e aplicação desejada. Figura 30. 


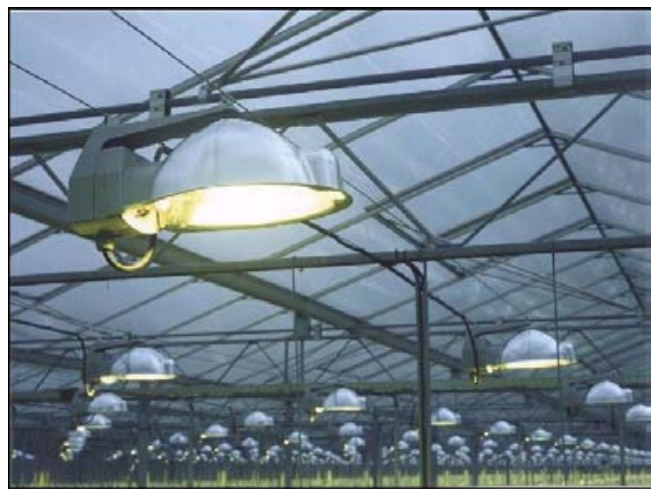

Fonte: P.L. Light (2003)

Figura 30 - Iluminação artificial

\subsubsection{Enriquecimento de $\mathrm{CO}_{2}$}

Os enriquecedores de $\mathrm{CO}_{2}$, também conhecidos por injetores de $\mathrm{CO}_{2}$, são utilizados para aumentar a concentração desse gás no interior da casa de vegetação. Existem basicamente duas maneiras utilizadas. A primeira é através de cilindros metálicos contendo gás carbônico líquido, que pode ser liberado para a atmosfera da casa de vegetação por meio de válvulas. A segunda é através da queima de hidrocarbonetos, por exemplo, gás natural e carvão. Segundo Rodríguez e Berenguel (2002), $1 \mathrm{~m}^{3} \mathrm{da}$ queima de gás natural produz $1.800 \mathrm{~g}$ de $\mathrm{CO}_{2}$ e $1.400 \mathrm{~g}$ de vapor d'água, devendo-se observar que a temperatura do gás gerado pode ser prejudicial à cultura. A figura 31 mostra um gerador de $\mathrm{CO}_{2}$ através da queima de gás natural.

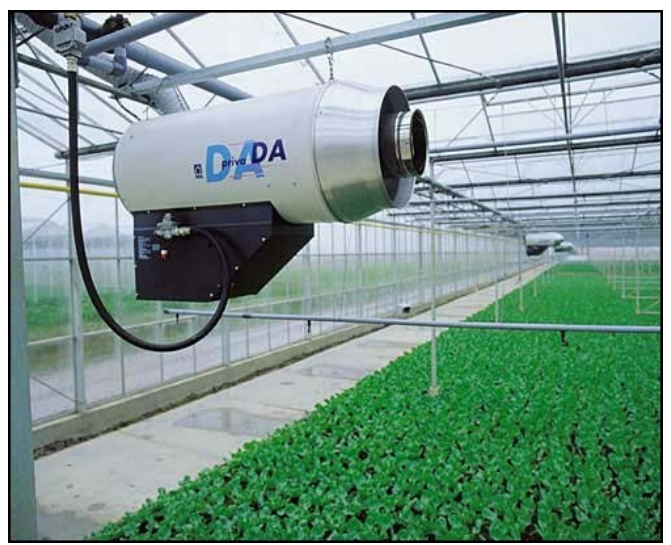

Fonte: Priva-a (2003)

Figura 31 - Gerador de $\mathrm{CO}_{2}$ 


\subsection{Algoritmos de controle}

Segundo Rodríguez e Berenguel (2002), existem quatro ações básicas de controle por realimentação: on-off, proporcional, derivativo e integral. Eles podem ser utilizados de forma individual ou em conjunto, de maneira a proporcionar outros tipos de algoritmos. Em controle climático de casa de vegetação os mais utilizados são os clássicos, ou seja: o on-off e o PID. Nas pesquisas são utilizados outros algoritmos mais elaborados como o adaptativo, o preditivo e o ótimo, entre outros.

Esquematicamente, um sistema de controle realimentado pode ser representado pela figura 32, abaixo:

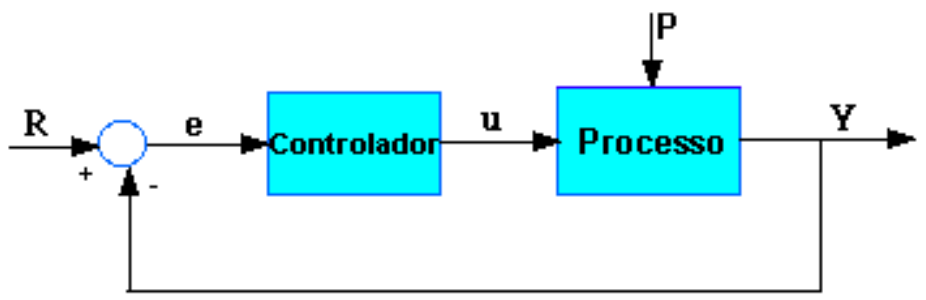

\section{Figura 32 - Sistema de controle com realimentação}

No esquema, "e" representa o desvio, também conhecido por erro, ou seja, a diferença entre o sinal de referência " $\mathbf{R}$ " e o valor atual da variável "Y". O sinal "u" é o sinal de saída gerado pelo controlador no intuito de corrigir a variável "Y", influenciada pela perturbação "P”, com o intuito de aproximá-la o mais possível ao valor de referência "R".

A seguir são apresentados alguns algoritmos comumente utilizados no controle de casas de vegetação:

\subsubsection{Clássicos}

- On-Off - Esse tipo de algoritmo apresenta duas saídas distintas e definidas: acionada ou desacionada. O comportamento desse sistema pode ser representado pela figura 33 . 


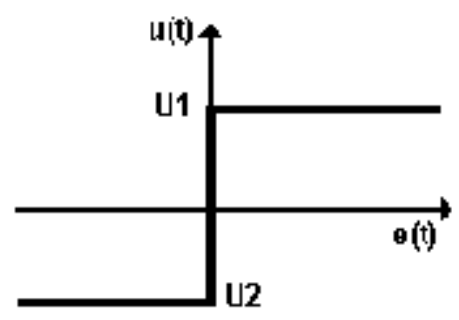

Figura 33 - Controle On Off

Pode-se notar que dependendo do valor do desvio e(t), ou seja, da diferença entre o valor de referência e o valor atual da variável, o sinal de saída u(t) apresenta apenas dois valores. A regra é $\mathrm{u}(\mathrm{t})=\mathrm{U} 1$ para valores de $\mathrm{e}(\mathrm{t})>0$, e $\mathrm{u}(\mathrm{t})=\mathrm{U} 2$ para valores de $\mathrm{e}(\mathrm{t})<0$. O principal inconveniente desse controlador está no momento do chaveamento entre os valores U1 e U2, ou seja, na zona de mudança, que pode causar oscilação do sistema. Por exemplo, ao se utilizar esse tipo de controlador para manter a temperatura em $25{ }^{\circ} \mathrm{C}$, ele poderá oscilar em torno desse valor, ligando os equipamentos de resfriamento quando a temperatura ultrapassar esse valor e desligando o mesmo quando a temperatura cair abaixo desse valor, podendo levar a um desgaste prematuro dos equipamentos. As seguintes técnicas são utilizadas para se contornar esse problema:

- Atraso - Caracteriza-se pelo fato de se fixar um período mínimo em que o controlador deve manter o sinal de saída $\mathrm{u}(\mathrm{t})$ fixo. Portanto, mesmo que a temperatura oscile com uma freqüência alta em torno do valor pré-determinado, o controlador oscilará com uma freqüência pré-definida pelo atraso.

○ Média - Nessa técnica o controlador não considera o valor imediato do desvio e $(\mathrm{t}) \mathrm{e}$, sim, uma média dos últimos valores medidos. A quantidade de amostras consideradas depende de experiência prévia no processo sob controle.

- Banda Neutra - Caracteriza-se pela definição de uma zona neutra de controle, ou seja, uma histerese. Voltando ao exemplo da temperatura, 
pode-se definir uma banda neutra entre 23 e $27{ }^{\circ} \mathrm{C}$, sendo que o controlador somente alterará o sinal de saída $\mathrm{u}(\mathrm{t})$ se o valor medido estiver fora dessa faixa.

- PID - Segundo Kempenich (1985), esse controlador e também é conhecido por controlador de "três modos", pois é resultado da associação dos três controladores: o proporcional (P), o integral (I) e o derivativo (D). $\mathrm{O}$ sinal de saída $u(t)$, dependente do tempo, pode ser expresso pela seguinte equação (1) num controlador PID:

$$
u(t)=K_{p} e(t)+K_{i} \int_{0}^{t} e(t) d t+K_{d} \frac{d e(t)}{d t}
$$

Onde:

$\mathrm{e}(\mathrm{t})=$ erro ou desvio

$\mathrm{K}_{\mathrm{p}}=$ Ganho proporcional

$\mathrm{K}_{\mathrm{i}}=$ Ganho Integral

$\mathrm{K}_{\mathrm{d}}=$ Ganho Derivativo

Basicamente, o sistema pode ser considerado como sendo a combinação de três controladores, responsáveis pelas seguintes ações:

○ Proporcional - A ação proporcional (P) gera um sinal de controle cuja amplitude de correção é proporcional à amplitude do erro ou desvio, proporcionando um tempo de estabilização relativamente curto.

- Integral - A ação integral (I) gera um sinal de controle cuja velocidade de correção é proporcional à amplitude do desvio. Esta ação é responsável pela eliminação do "offset" existente no controlador proporcional.

- Derivativa - A ação derivativa (D) gera um sinal de controle cuja amplitude de correção é proporcional à velocidade do erro ou desvio, 
reduzindo, dessa forma, o tempo de estabilização e também o erro ou desvio máximo.

É importante observar que o controlador PID é utilizado quando se deseja uma rápida correção do desvio, juntamente com um desvio máximo reduzido. Existem algumas aplicações na qual a utilização da ação derivativa (D) tornase contraproducente por apresentar variações rápidas devidas a ruídos. Como exemplo pode-se citar o controle de vazão. No controle da temperatura em casa de vegetação a utilização do controle proporcional-integral (PI) pode ser particularmente interessante, tendo em vista que a velocidade de variação da temperatura pode ser acentuada devido a um fluxo de ar não uniforme e também com temperatura não homogênea, levando a geração de ruídos indesejáveis.

\subsubsection{Adaptativo}

O algoritmo adaptativo tem a propriedade de modificar o comportamento do controlador em função das novas condições do ambiente. O controlador adaptativo modifica o valor dos seus parâmetros em função dos valores das variáveis de perturbação. A adaptação pode ser realizada de duas formas:

- Controle com malha aberta - Consiste na modificação dos parâmetros do controlador em função de uma tabela previamente levantada para determinados pontos e condições das perturbações. O principal inconveniente desse algoritmo é o tempo necessário para o levantamento da tabela e sua extrapolação para outras situações de controle.

- Controle com malha fechada - Esse algoritmo, ao invés de utilizar as tabelas previamente levantadas, utiliza-se da realimentação paralela à realimentação principal do processo. Essa realimentação avalia um índice de funcionamento do processo e em função desse índice altera o valor original gerado pelo regulador do sistema, visando adaptar o sistema à nova condição. 


\subsubsection{Preditivo}

Também conhecido como antecipativo. Diferentemente dos outros algoritmos utilizados, que primeiramente verificam a alteração nas variáveis controladas para depois atuarem nos parâmetros de controle no sentido de corrigi-las, o algoritmo preditivo tem a característica de alterar o valor da saída de controle $u(t)$ em função das perturbações existentes, antes que elas alterem as variáveis monitoradas. Para que esse algoritmo tenha um bom desempenho é necessário que se conheça muito bem o modelo do processo para que se possa calcular a ação de controle necessária para compensar o efeito da perturbação. O levantamento do modelo não é trivial e pode ser feito por simulação.

\subsection{4 Ótimo}

Este algoritmo é baseado na existência de distintas soluções para um determinado problema. Dentre essas soluções, seleciona-se aquela que apresenta um melhor resultado, considerado ótimo. Esse conceito pode ser utilizado sempre que se consiga definir um conjunto $U$ de possíveis soluções e exista uma função de custo $F(u)$ que resulte um valor para cada uma das soluções individuais $\left(\mathrm{u}_{\mathrm{i}}\right)$. A melhor solução será aquela para a qual a função $\mathrm{F}(\mathrm{u})$ tenha o mínimo valor. Esse conceito aplicado no campo de controle automático consiste em encontrar sinais de controle $u(t)$, onde $t \in$ $[0, T]$, que minimizem a função de custo F. O objetivo desse tipo de algoritmo é maximizar a diferença entre o valor do cultivo e os custos de produção. 


\section{CAPÍTULO 4}

\section{AGRILOGIC - SISTEMA PARA EXPERIMENTAÇÃO DE CONTROLE CLIMÁTICO DE CASAS DE VEGETAÇÃO}


Este capítulo descreve a implementação do Agrilogic, tendo como base sua arquitetura e organização, software e testes os funcionais realizados.

\section{AGRILOGIC - SISTEMA PARA EXPERIMENTAÇÃO DE CONTROLE CLIMÁTICO DE CASAS DE VEGETAÇÃO}

\subsection{Introdução}

O estudo do domínio da produção agrícola em casas de vegetação com ambiente controlado que foi realizado como etapa inicial deste trabalho revelou diversos aspectos importantes.

Em primeiro lugar pôde-se constatar a importância das casas de vegetação no mundo e seu crescimento no Brasil. O controle de ambiente em casas de vegetação é aspecto decisivo no refinamento dessa forma de produção e na obtenção de melhores produtos e maior produtividade.

A análise do mercado nacional realizada junto aos principais fornecedores de casas de vegetação e de equipamentos revelou a escassez de soluções para o problema do controle ambiental.

Existem poucas empresas nacionais com produtos especificamente dedicados a esse mercado, que é atendido por soluções importadas ou por sistemas integrados a partir de subsistemas de propósito geral, voltados prioritariamente para automação industrial.

Não pôde ser identificado nenhum produto nacional com controle climático feito de uma forma integrada.

Verificou-se também o interesse demonstrado pelo desenvolvimento de tecnologia nacional, com funções simples e a um preço acessível. 
As questões da qualidade e confiabilidade, da simplicidade funcional e da robustez do produto são de fundamental importância, pois:

- O produto estará sujeito a condições adversas típicas de uma casa de vegetação.

- O produto será utilizado por agricultores, os quais conhecem muito bem sobre a cultura, porém às vezes apresentam dificuldade natural no manuseio de sistemas informatizados por ser uma tecnologia relativamente nova.

- O produto poderá ser submetido ao fornecimento de energia elétrica de baixa qualidade, característica da energia elétrica no meio rural.

- Em caso de falha, o produto poderá comprometer o trabalho de toda uma safra.

Essa situação motivou inicialmente o desenvolvimento deste trabalho. Por outro lado há um interesse do Laboratório de Abelhas do IB-USP, grupo de pesquisa com o qual o LAA vem desenvolvendo uma parceria profícua, no estudo do uso de polinizadores nativos dentro de casas de vegetação.

O IB-USP dispõe inclusive de uma casa de vegetação adequada para um trabalho experimental em controle de ambiente, a qual dispõe de equipamentos eletromecânicos básicos para controle ambiental, sem, no entanto, haver como utilizá-los de forma programável, automática e integrada.

O próprio Laboratório de Abelhas dispunha ainda de um CLP que poderia ser cedido para o controle climático da casa de vegetação.

Esse conjunto de fatores e interesses levou à proposição deste trabalho no formato atual, que permite montar uma infra-estrutura de pesquisa em controle climático em casas de vegetação praticamente sem custo adicional.

Além disso, reforça-se a parceria dessas duas unidades e grupos de pesquisa da USP (Universidade de São Paulo), com a perspectiva de se desenvolverem trabalhos multidisciplinares. 


\subsection{Arquitetura e Organização}

Esquematicamente, o Agrilogic pode ser visualizado na figura 34 abaixo:

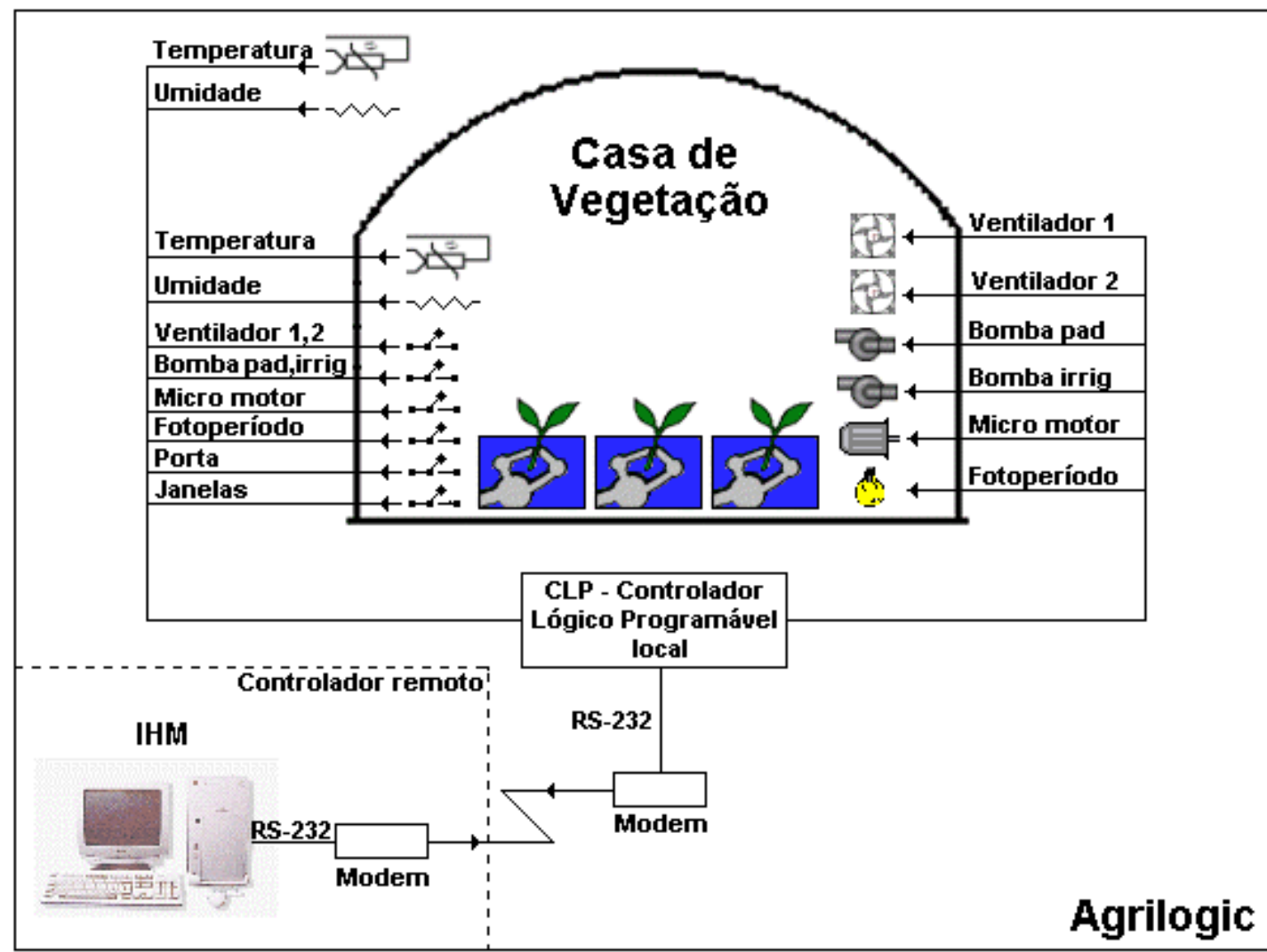

Figura 34 - Arquitetura e Organização do Agrilogic

$\mathrm{Na}$ região central do diagrama está representado o processo através da casa de vegetação do IB-USP.

No lado esquerdo do diagrama estão representados os sensores utilizados para a monitoração do processo. Existem dois grupos de sensores, os que monitoram as condições climáticas internas e externas, no caso, temperatura e umidade, e os sensores que monitoram o estado dos elementos que influenciam nessas condições climáticas, como equipamentos, porta e janelas. Esse último grupo de sensores trabalha fornecendo informações do tipo digital, ou seja, se os equipamentos estão ligados ou desligados, e se a porta e as janelas estão abertas ou fechadas. 
No lado direito do diagrama estão representados os elementos atuadores passíveis de controle como os dois ventiladores utilizados como exaustores, a bomba pad utilizada principalmente para resfriamento, a bomba de irrigação utilizada para aumentar a umidade relativa do ar, o micro motor responsável por manter a cobertura da casa de vegetação insuflada e as lâmpadas responsáveis pelo controle de fotoperíodo.

Um CLP local é utilizado para receber os sinais provenientes dos sensores, avaliá-los em função de um algoritmo pré-estabelecido, e promover o acionamento dos elementos necessários para manter as variáveis climáticas dentro da faixa préprogramada. Esse CLP está conectado a um modem através de uma interface RS-232 com a finalidade de enviar informações de monitoração e receber comandos de uma estação de controle e supervisão remota, através da utilização de uma linha telefônica. Essa conexão telefônica permite ainda a reprogramação do CLP de uma forma remota.

No canto esquerdo inferior está representada a estação de supervisão e controle que possui duas funcionalidades principais. A primeira é proporcionar uma IHM mais amigável e intuitiva e a segunda é permitir a alteração do programa do CLP de uma forma remota. Essa estação está conectada a um modem via interface RS-232, com a finalidade de enviar comandos e receber informações de monitoração provenientes do CLP e ainda reprogramar o CLP através da utilização de uma linha telefônica.

Seguindo a mesma linha de apresentação feita no capítulo anterior, o Agrilogic pode ser dividido em quatro grupos funcionais: processo, atuadores, sensores e controlador, sendo que este último, em função da sua proximidade com o processo, pode ser subdividido em dois subgrupos: local e remoto.

\subsubsection{Processo}

O processo a ser controlado é a casa de vegetação modelo teto em arco do IB-USP. Ela possui um comprimento de $18,50 \mathrm{~m}$ e uma largura de $6,20 \mathrm{~m}$ perfazendo uma área total de aproximadamente de $116,50 \mathrm{~m}^{2}$. Ela possui $3,00 \mathrm{~m}$ de altura do pé direito e $1,50 \mathrm{~m}$ de altura da concavidade do arco, atingindo $4,50 \mathrm{~m}$ de altura na 
região central. Contém uma porta lateral corrediça, localizada do lado direito, duas janelas laterais, uma de cada lado, com acionamento manual. Possui também duas janelas zenitais, localizadas na frente e fundos, com acionamento manual. Ela foi construída pela empresa Van der Hoeven, de Holambra-SP. Figura 35.
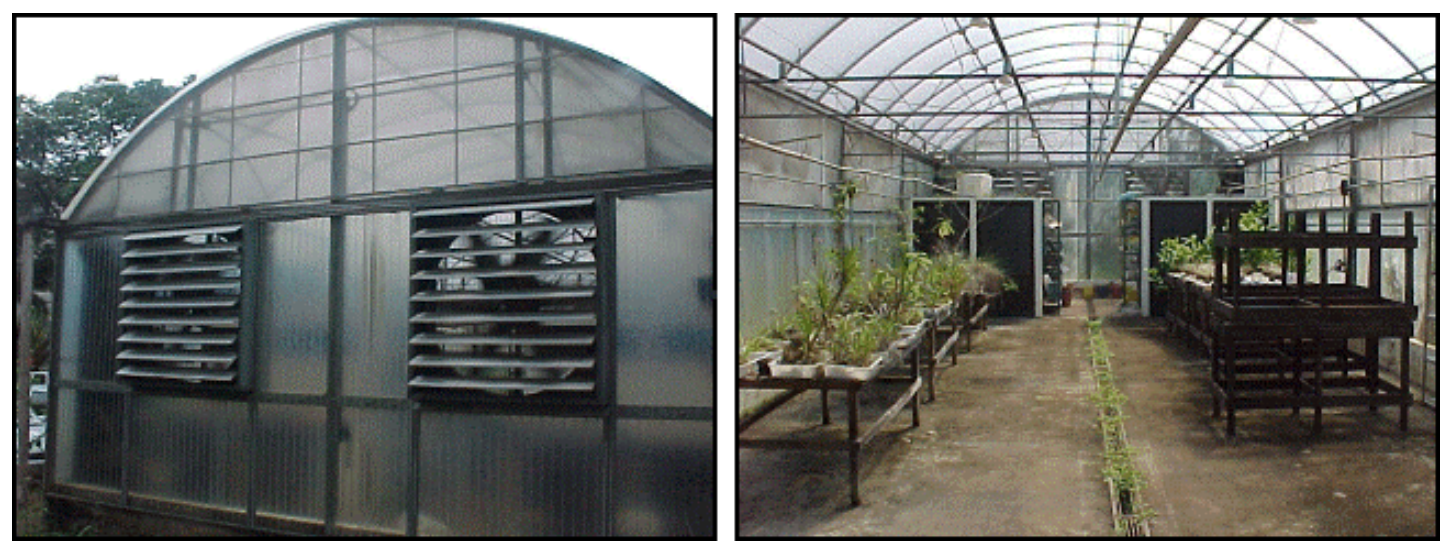

Figura 35 - Vista externa e interna da casa de vegetação do IB-USP

As coordenadas geográficas aproximadas da casa de vegetação são: $23^{\circ} 39^{\prime}$ de latitude sul e $46^{\circ} 37^{\prime}$ de longitude oeste. Está localizada a uma altitude de aproximadamente 800 metros em relação ao nível do mar. O eixo longitudinal da estrutura possui uma orientação em relação ao norte magnético de $20^{\circ}$ aproximadamente, no sentido sudeste (SE) para o noroeste (NO), com a frente direcionada para nordeste. Figura 36.

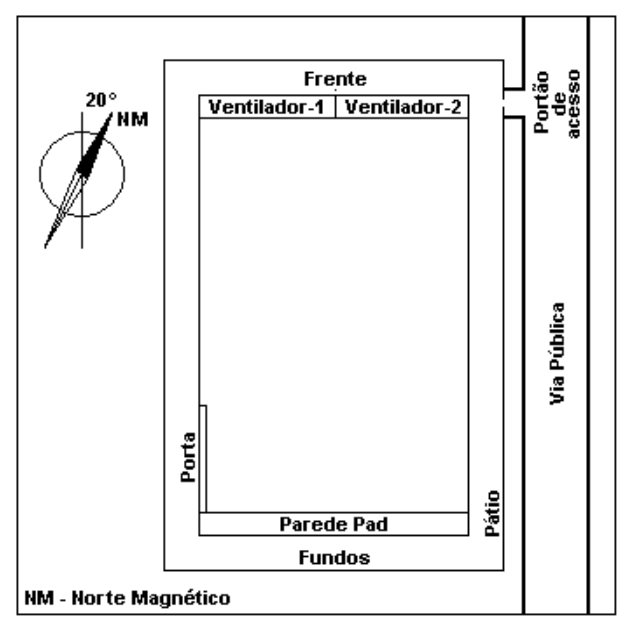

Figura 36 - Localização geográfica da casa de vegetação do IB-USP 


\subsubsection{Atuadores}

Os seguintes equipamentos estão disponíveis na casa de vegetação com a finalidade de se manter as variáveis climáticas o mais próximo possível dos valores de referência desejáveis:

- Ventiladores - Existem dois ventiladores frontais, acionados por motores de 1,5 CV (Cavalo Vapor) cada. O sistema de transmissão é através de correia, o qual proporciona um rendimento melhor. O diâmetro da hélice é de 1250 mm, com uma velocidade de rotação de 455 RPM. Cada ventilador permite um deslocamento nominal de ar de $34,75 \mathrm{~m}^{3} /$ hora. Os ventiladores são providos de uma veneziana externa, a qual se abre automaticamente quando o ventilador é acionado. Esse mecanismo serve para evitar a entrada de insetos na casa de vegetação, quando o ventilador está desligado. Figura 37.

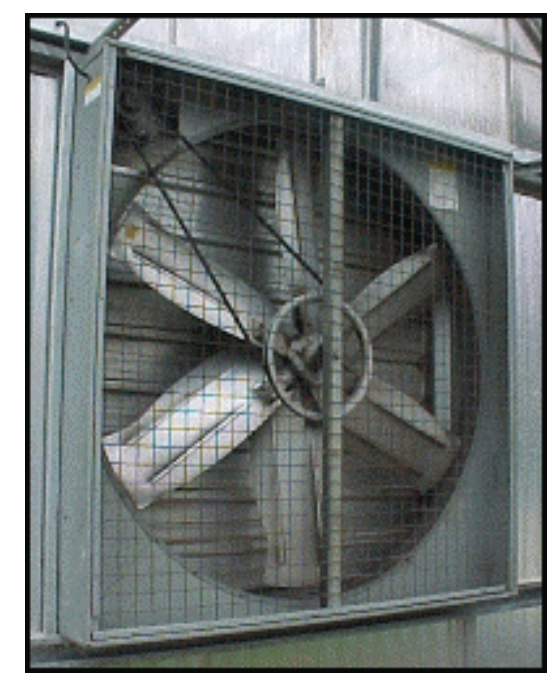

Figura 37 - Ventilador da casa de vegetação IB-USP, vista interna

- Bombas - Existem duas bombas de 1,0 CV cada para as funções de recalque d'água para o sistema pad-fan e para o sistema de irrigação.

- Micro motor - Equipamento utilizado para manter a cobertura da casa de vegetação inflada, pois ela é constituída por duas camadas plásticas, com uma 
camada de ar entre elas. O micro motor possui uma potência de 1/30 CV. Figura 38.

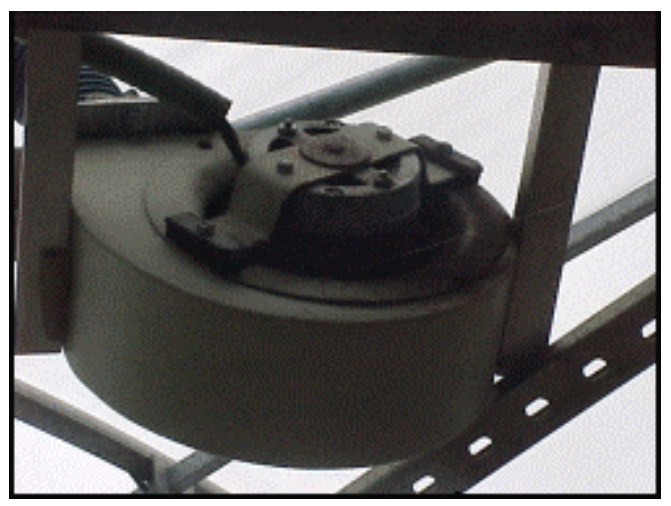

Figura 38 - Micro motor da casa de vegetação do IB-USP

- Lâmpadas - O sistema de iluminação é composto de 36 lâmpadas incandescentes distribuídas regularmente em quatro linhas longitudinais com 9 lâmpadas cada uma, cuja finalidade é permitir o controle do fotoperíodo. Figura 39.

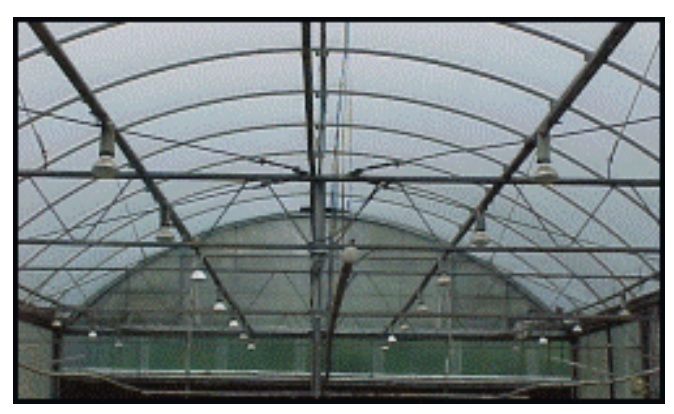

Figura 39 - Lâmpadas de fotoperíodo da casa de vegetação do IB-USP

Esses equipamentos podem ser controlados manualmente através do armário de controle original, o qual possui uma chave geral que desliga todos os equipamentos. O controle do micro motor e das lâmpadas pode ser realizado pela operação de chaves de duas posições: ligado e desligado. O controle dos ventiladores e das bombas pode ser realizado pela operação de chaves de três posições que permitem selecionar entre: 
- Manual - Nesta posição, os equipamentos são acionados independentemente das condições climáticas presentes na casa de vegetação.

- Automático - Nesta posição, os equipamentos são acionados ou não, dependendo das condições climáticas presentes na casa de vegetação e dos valores de referência ajustados para a temperatura e umidade, conforme detectados por um termostato e um higrômetro.

- Desligado - Nesta posição, os equipamentos são desacionados independentemente das condições climáticas presentes na casa de vegetação.

A monitoração visual do estado dos equipamentos é realizada por meio de lâmpadas piloto posicionadas junto às chaves de controle. Existe também uma lâmpada piloto, posicionada na região superior do armário de controle, que sinaliza se a chave geral do armário está ou não ligada. Figura 40.
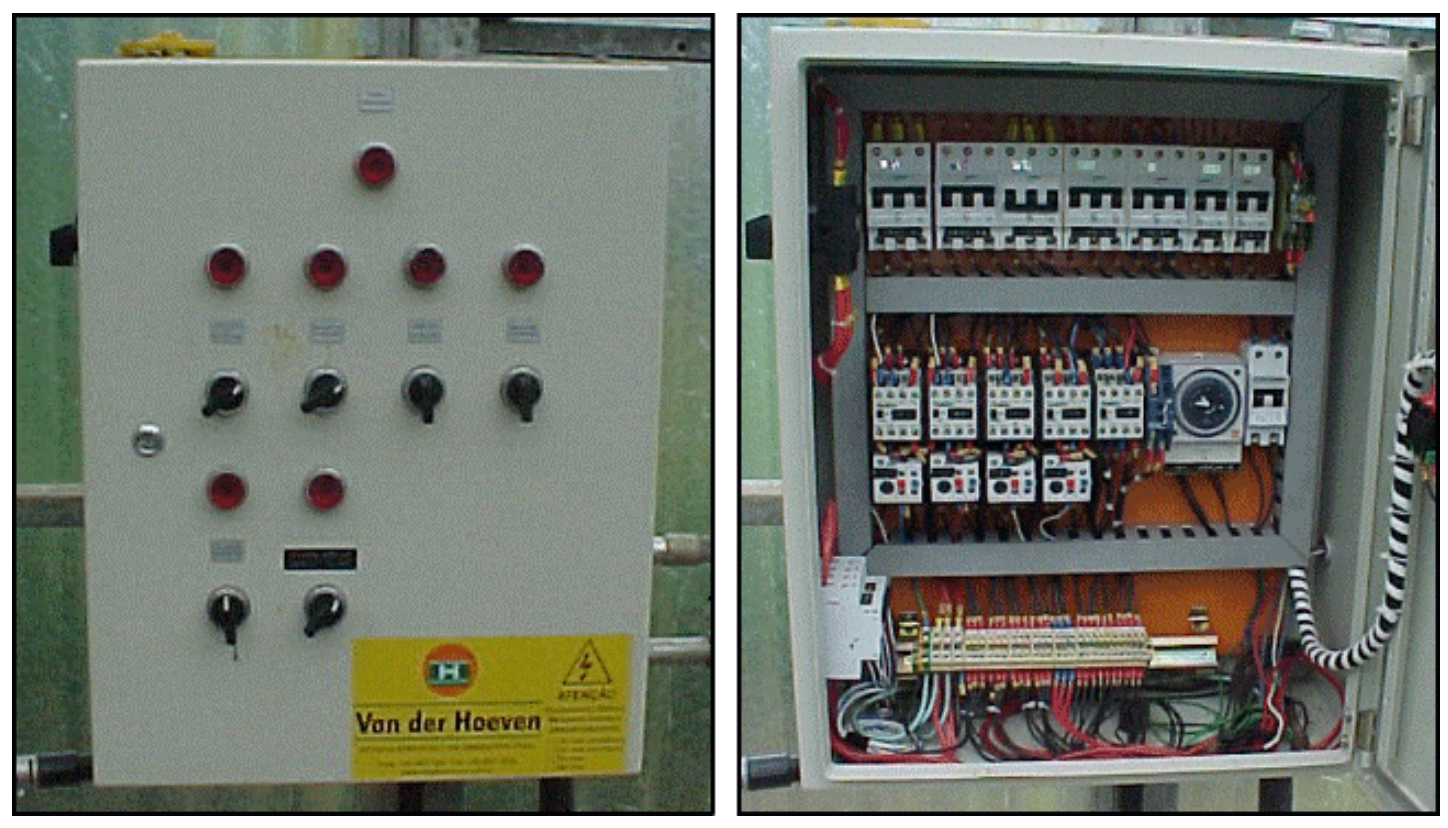

\section{Figura 40 - Vista externa e interna do armário de controle da casa de vegetação} do IB-USP

A distribuição dos equipamentos da casa de vegetação é um fator importante, pois pode influenciar no desempenho do sistema como um todo. Por exemplo, os ventiladores ficam na parede oposta do sistema pad-fan, permitindo uma melhor 
eficiência no processo de resfriamento do ambiente interno. A figura 41 mostra a vista superior da distribuição dos equipamentos da casa de vegetação do IB-USP.

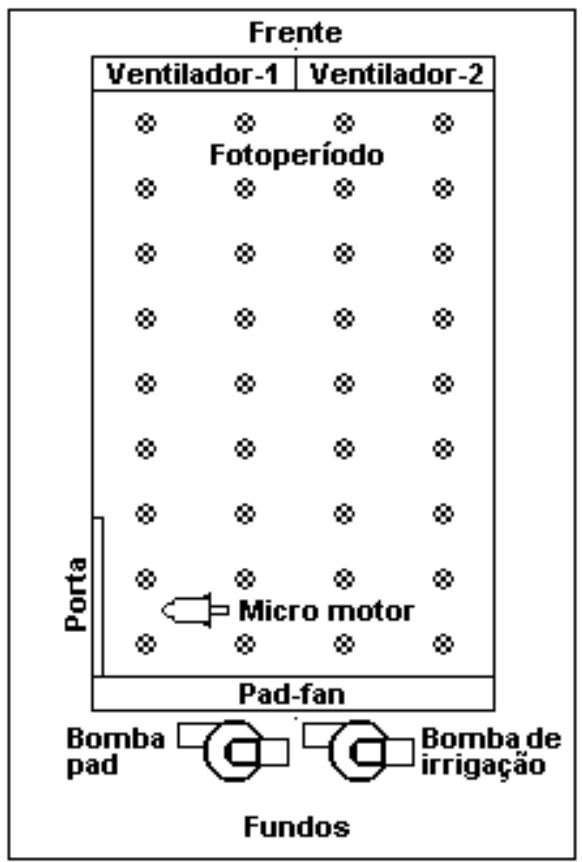

Figura 41 - Distribuição dos equipamentos da casa de vegetação do IB-USP, vista superior

\subsubsection{Sensores}

O Agrilogic foi concebido para controlar as seguintes variáveis físicas:

- Temperatura - Para a monitoração da temperatura foram utilizados cinco sensores do tipo RTD Pt 100 de três terminais, para compensar o comprimento do cabo.

○ Especificações técnicas:

Faixa de operação: $-200{ }^{\circ} \mathrm{C} \mathrm{a}+850{ }^{\circ} \mathrm{C}$.

Exatidão: $\pm(0,15+0,002[\mathrm{t}])$ para sensores classe A e $\pm(0,30+0,005[\mathrm{t}])$ para sensores classe B.

Onde $[\mathrm{t}]$ representa a temperatura em ${ }^{\circ} \mathrm{C}$. 
Sensibilidade: $0,385 \Omega /{ }^{\circ} \mathrm{C}$.

Tempo de resposta típico: $87 \mathrm{~s}$ no ar a $1 \mathrm{~m} / \mathrm{s}$.

- Umidade - Para a monitoração da umidade foram utilizados três sensores EWHS 280 da empresa "Invensys Control". O fabricante recomenda que, para se obterem medições precisas, o sensor deve permanecer no ambiente por um determinado tempo, pois ele possui uma massa que pode afetar a medida. Outra recomendação importante é que leituras errôneas podem ocorrer caso ele seja submetido a ambientes em que ocorra a condensação de água no sensor. Esse sensor é adequado para a utilização, pois apresenta a faixa de operação utilizada nos experimentos da casa de vegetação.

○ Especificações técnicas:

Faixa de operação: $15 \%$ a $90 \%$.

Exatidão: $\pm 5 \%$ umidade relativa.

Tempo de resposta em condição estável: $60 \mathrm{~s}$.

Sensibilidade: $5 \% / \mathrm{mA}$.

Esses sensores foram fixados na estrutura da casa de vegetação por suporte de ferro galvanizado. Figura 42.
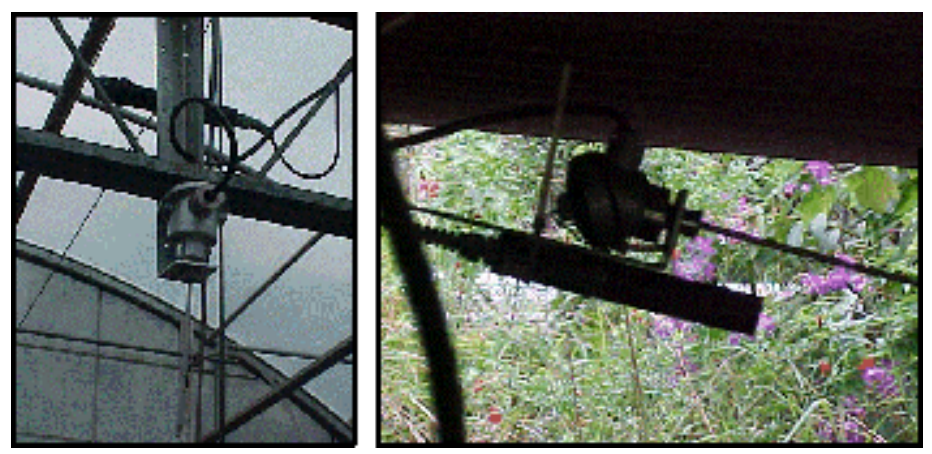

Figura 42 - Vista interna e externa dos sensores de temperatura e umidade da casa de vegetação do IB-USP 
Os sensores foram dispostos internamente e externamente à casa de vegetação. Os internos foram colocados a uma distância aproximada de $1,90 \mathrm{~m}$ do solo e espaçados a uma distância de 3,70 m entre eles. A altura de posicionamento ideal é a das bancadas de experimentação, que possuem $1,00 \mathrm{~m}$, pois permite a monitoração das condições climáticas próximas dos vegetais. A altura de $1,90 \mathrm{~m}$ foi utilizada para que os sensores fiquem acima da tubulação de irrigação e não sejam atingidos por água no estado líquido, o que poderia provocar danos aos sensores e proporcionar leituras errôneas. Os externos foram colocados sob um barracão de proteção da caixa d'água das bombas pad e de irrigação, a uma altura aproximada de 1,0 m do solo. Vale a pena observar que o posicionamento externo dos sensores retrata uma condição particular, pois como os sensores não têm a devida proteção para serem utilizados externamente, suas medidas podem ser influenciadas pelo seu aquecimento, devido à ação direta do sol e pela precipitação de chuva. Figura 43.

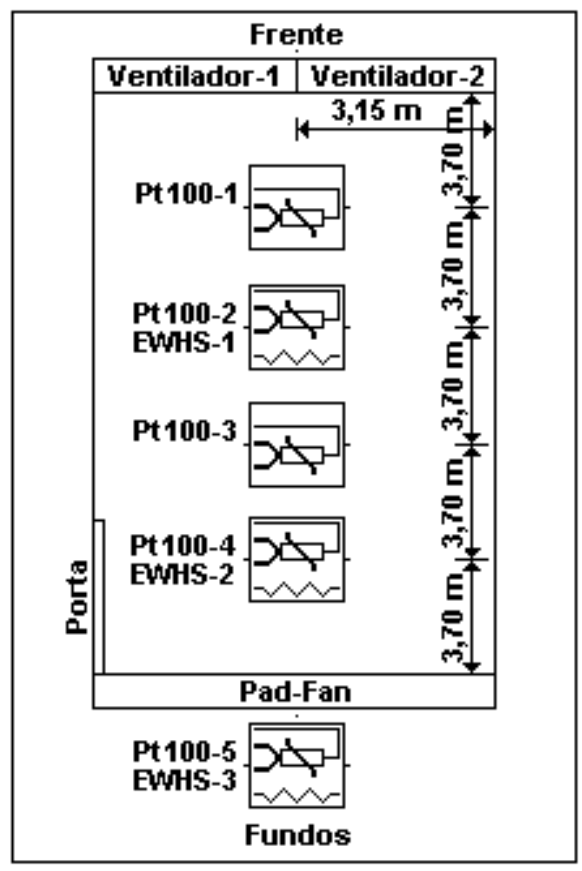

Figura 43 - Distribuição dos sensores da casa de vegetação do IB-USP

\subsubsection{Controlador local}

O controlador local é baseado em CLP e foi utilizado o sistema disponível no IBUSP, adquirido originalmente para fazer a monitoração e o controle das colméias no 
Laboratório de Abelhas. O sistema é baseado em produtos da marca Klockner Moeller, composto pelo CLP, dois módulos de expansão remota para sensor de temperatura e um módulo de expansão remota para sensores analógicos em geral. Figura 44.

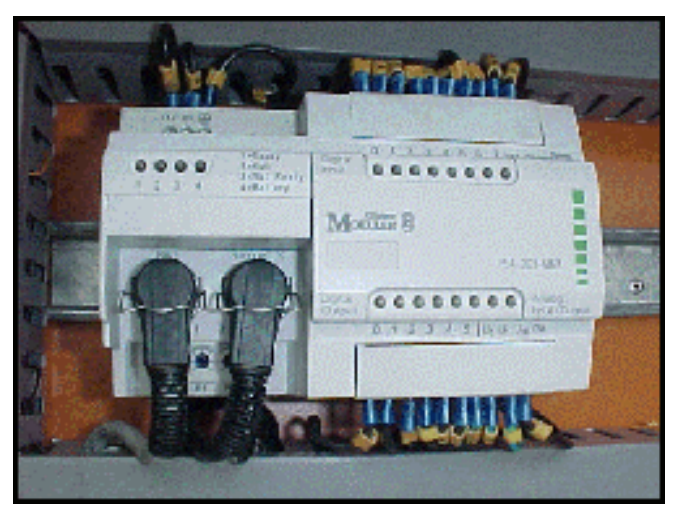

Figura 44 - CLP PS4-201-MM1 da casa de vegetação do IB-USP

- CLP - O modelo utilizado foi o PS4-201-MM1 que é um controlador compacto com 32 Kbytes de memória para programação e com os seguintes recursos:

○ 8 entradas digitais de 24 VDC.

Essas entradas foram utilizadas para monitorar os equipamentos, a porta e as janelas. Em função de as entradas trabalharem com sinais digitais, nos quais o nível lógico um é adotado para sinais com tensões iguais ou superiores a 15 VDC e o nível lógico zero é adotado para sinais com tensões iguais ou inferiores a 5 VDC, utilizou-se um circuito resistivo para atender a essas especificações.

Oito circuitos idênticos foram montados em uma barra de bornes e identificados como entradas digitais. Figura 45. 


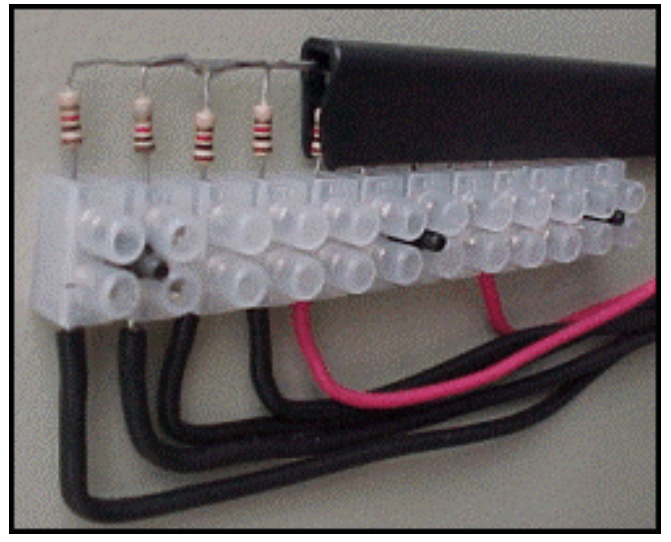

\section{Figura 45 - Circuito resistivo para entrada digital - Montagem}

A seguir apresenta-se a relação das entradas e dos dispositivos monitorados. Adotou-se a simbologia utilizada pelo fabricante do controlador, na qual ".X" corresponde ao bit "X" do byte de controle.

.0 Monitora se o ventilador 1 está ligado, nível lógico zero, ou desligado, nível lógico um.

.1 Monitora se o ventilador 2 está ligado, nível lógico zero, ou desligado, nível lógico um.

.2 Monitora se a bomba pad está ligada, nível lógico zero, ou desligada, nível lógico um.

.3 Monitora se a bomba de irrigação está ligada, nível lógico zero, ou desligada, nível lógico um.

.4 Monitora se o micro motor está ligado, nível lógico zero, ou desligado, nível lógico um.

.5 Monitora se o sistema de fotoperíodo está ativo, nível lógico zero, ou inativo, nível lógico um.

.6 Monitora se a porta está aberta, nível lógico zero, ou fechada, nível lógico um. 
.7 Monitora se alguma das quatro janelas está aberta, nível lógico zero, ou se todas estão fechadas, nível lógico um.

- 6 saídas digitais de 24 VDC, com capacidade de 0,5 A cada.

Essas saídas foram utilizadas para controlar os equipamentos existentes na casa de vegetação. Devido à necessidade de se controlar equipamentos com potência considerável, foi necessária a utilização de um circuito, baseado em transistor e relé, para acionar os contatores desses dispositivos. Seis circuitos idênticos foram montados e encapsulados na caixa de relés acionadores. Figura 46.

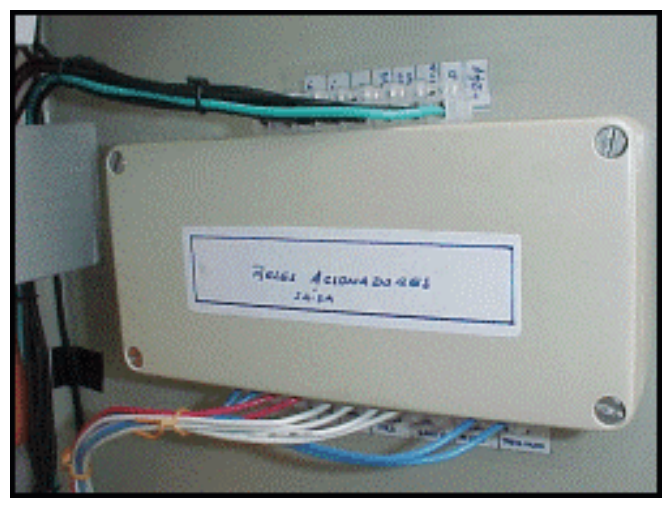

Figura 46 - Circuito de relés acionadores - Montagem

A seguir apresenta-se a relação das saídas e dos equipamentos controlados. De forma análoga à simbologia utilizada para as entradas, ".X" corresponde ao bit "X" do byte de controle.

.0 Essa saída digital é responsável pelo controle do ventilador 1 . Em nível lógico um o ventilador 1 estará ligado e em nível lógico zero o equipamento estará desligado.

.1 Essa saída digital é responsável pelo controle do ventilador 2 . Em nível lógico um o ventilador 2 estará ligado e em nível lógico zero o equipamento estará desligado. 
.2 Essa saída digital é responsável pelo controle da bomba pad. Em nível lógico um, a bomba estará ligada e em nível lógico zero, o equipamento estará desligado.

.3 Essa saída digital é responsável pelo controle da bomba de irrigação. Em nível lógico um, a bomba estará ligada e em nível lógico zero, o equipamento estará desligado.

.4 Essa saída digital é responsável pelo controle do micro motor. Em nível lógico um, o motor estará ligado e em nível lógico zero, o equipamento estará desligado.

.5 Essa saída digital é responsável pelo controle do sistema de fotoperíodo. Em nível lógico um, o sistema estará ativo e em nível lógico zero, o sistema estará inativo.

○ 2 entradas analógicas $\mathrm{U}_{0}$ e $\mathrm{U}_{1}$ de 0 a $10 \mathrm{~V}$ com resolução de 10 bits.

Essas entradas não foram utilizadas no presente trabalho.

- 1 saída analógica $U_{10}$ de 0 a $10 \mathrm{~V}$ com resolução de 12 bits.

Essa saída não foi utilizada no presente trabalho.

○ 2 potenciômetros P1 e P2 para ajuste de valor de referência "set point" com resolução de 10 bits.

Esses potenciômetros não foram utilizados no presente trabalho.

- 4 LEDs indicativos do estado operacional do CLP. O primeiro LED (Ready) sinaliza que o CLP está com o programa carregado na memória e está pronto para ser executado. Nesse modo de operação as saídas estão desabilitadas. O segundo LED (Run) sinaliza que o programa está sendo executado ciclicamente. O terceiro LED (Not ready) sinaliza que o CLP não está executando o programa devido às seguintes causas prováveis: não existe programa na memória, falha de 
hardware ou falha grave no programa que levou a uma violação do tempo de execução. E finalmente o quarto LED (Battery) sinaliza se a bateria do CLP está ou não em boas condições.

A configuração do módulo PS4-201-MM1 pode ser vista na figura 47 abaixo:

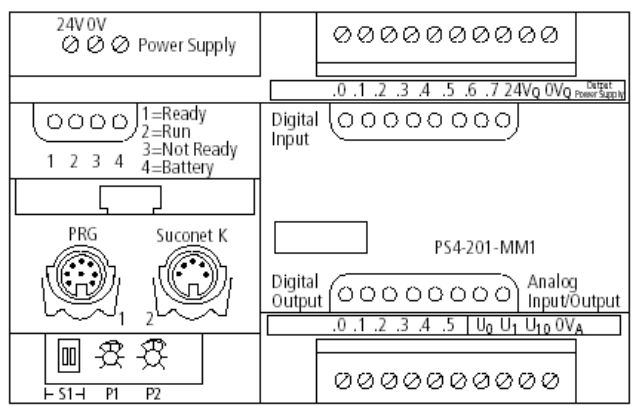

Fonte: Albrecht (1999)

\section{Figura 47 - Controlador compacto PS4-201-MM1}

- Módulo de expansão remota para sensor de temperatura - O módulo utilizado foi o EM4-101-TX1, o qual pode processar até 6 valores analógicos tais como temperatura, pressão do ar, umidade e volume. Embora haja a disponibilidade de dois módulos de temperatura, foi utilizado apenas um, pois existem apenas cinco sensores de temperatura no Agrilogic. Figura 48.

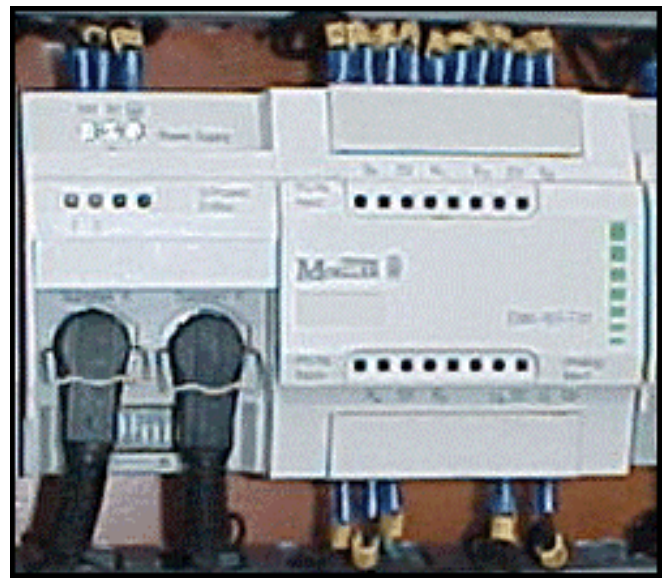

Figura 48 - Módulo de expansão remota para sensor de temperatura 
Ele pode ser conectado ao sistema CLP via barramento proprietário, conhecido como Suconet K. O módulo possui os seguintes recursos:

- 6 entradas analógicas para sensores de temperatura RTD do tipo Pt 100 e Ni 1000. Essas entradas possuem uma resolução de 12 bits, variando de $-100{ }^{\circ} \mathrm{C}$ para o valor $(\mathrm{FC} 18)_{\mathrm{H}} \mathrm{a}+300{ }^{\circ} \mathrm{C}$ para o valor $(05 \mathrm{DC})_{\mathrm{H}}$. O fabricante adota a nomenclatura $\mathrm{R}_{\mathrm{X}}$ para essas entradas onde "x" é o número seqüencial das entradas.

$\mathrm{R}_{0} \quad$ Essa entrada analógica é responsável pela monitoração do sensor Pt 100-1.

$\mathrm{R}_{1}$ Essa entrada analógica é responsável pela monitoração do sensor Pt 100-2.

$\mathrm{R}_{2}$ Essa entrada analógica é responsável pela monitoração do sensor Pt 100-3.

$\mathrm{R}_{3} \quad$ Essa entrada analógica é responsável pela monitoração do sensor Pt 100-4.

$\mathrm{R}_{4}$ Essa entrada analógica é responsável pela monitoração do sensor Pt 100-5.

$\mathrm{R}_{5}$ Essa entrada analógica não foi utilizada no presente trabalho.

○ 2 entradas analógicas $\mathrm{U}_{0}$ e $\mathrm{U}_{1}$ de 0 a $10 \mathrm{~V}$ com resolução de 12 bits.

Essas entradas analógicas não foram utilizadas no presente trabalho.

Esse módulo possui a característica de detectar a ocorrência de curto-circuito ou abertura dos cabos de sinais. As especificações técnicas das entradas analógicas para os sensores Pt 100 são:

○ Faixa de operação: $-100{ }^{\circ} \mathrm{C} \mathrm{a}+300{ }^{\circ} \mathrm{C}$.

Desvio: $\pm 0,4 \%$ máximo e $\pm 0,2 \%$ típico. 
Fator de linearidade: $\pm 0,15 \%$ máximo.

Exatidão: $\pm 0,3{ }^{\circ} \mathrm{C}$.

Resolução: $0,1^{\circ} \mathrm{C}$ (alta resolução - 12 bits quantização).

A configuração do módulo de expansão remota EM4-101-TX1 pode ser vista na figura 49.

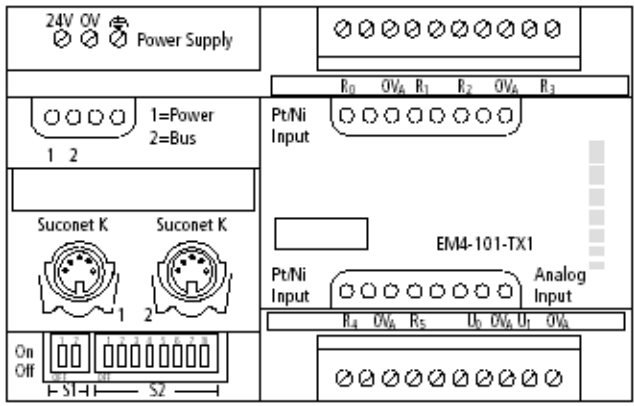

Fonte: Großpietsch (1996)

\section{Figura 49 - Módulo de expansão remota EM4-101-TX1}

- Módulo de expansão remota para sensores e atuadores analógicos em geral O módulo utilizado foi o EM4-101-AA2. Esse módulo pode ser utilizado tanto para monitoração em tensão $(0$ a $10 \mathrm{~V})$ como em corrente $(0$ a $20 \mathrm{~mA})$, bem como para controlar atuadores por meio de variação na tensão. Figura 50 .

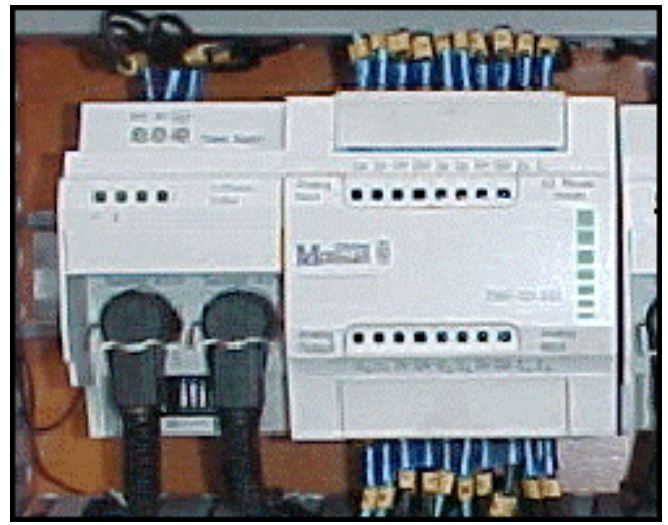

Figura 50 - Módulo de expansão remota para sensor de umidade 
Ele pode ser conectado ao sistema CLP via barramento proprietário Suconet K. Este módulo possui os seguintes recursos:

○ 4 entradas analógicas para tensão de 0 a $10 \mathrm{~V}$, com resolução de 12 bits.

Essas entradas analógicas não foram utilizadas no presente trabalho.

○ 4 entradas analógicas para corrente de 0 a $20 \mathrm{~mA}$, com resolução de 12 bits.

$\mathrm{I}_{0} \quad$ Essa entrada analógica é responsável pela monitoração do sensor de umidade EWHS-1.

$\mathrm{I}_{1} \quad$ Essa entrada analógica é responsável pela monitoração do sensor de umidade EWHS-2.

$\mathrm{I}_{2}$ Essa entrada analógica é responsável pela monitoração do sensor de umidade EWHS-3.

$\mathrm{I}_{3} \quad$ Essa entrada analógica não foi utilizada no presente trabalho.

○ 4 saídas analógicas 0 a $10 \mathrm{~V}$ com resolução de 12 bits.

Essas saídas analógicas não foram utilizadas no presente trabalho.

As especificações técnicas das entradas analógicas para os sensores EWHS são:

○ Faixa de operação: $0 \mathrm{~mA}$ a $+20 \mathrm{~mA}$.

Desvio: $\pm 0,4 \%$ máximo.

Resolução: 4,882 $\mu \mathrm{A}$ (alta resolução - 12 bits quantização).

Impedância de entrada: 50 Ohms.

A configuração do módulo de expansão remota EM4-101-AA2 pode ser vista na figura 51. 


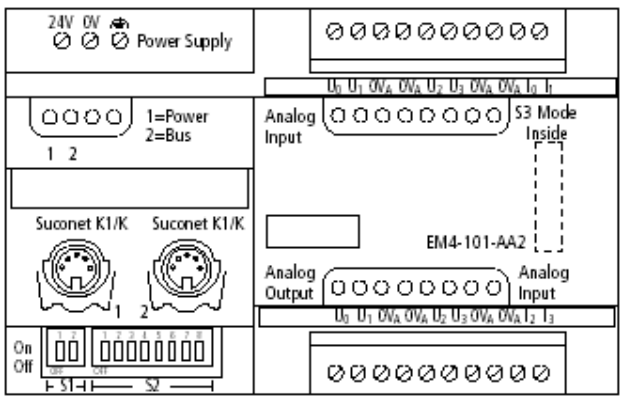

Fonte: Roersch (2001)

\section{Figura 51 - Módulo de expansão remota EM4-101-AA2}

Um estudo cuidadoso foi elaborado no sentido de se preservarem as ligações elétricas originais do fabricante da casa de vegetação do IB-USP. Uma chave geral foi instalada no armário de controle para possibilitar o desligamento total do armário de CLP, fazendo com que a operação da casa de vegetação seja retomada no seu conceito original, baseada em lógica de relés, projetada pelo fabricante Van der Hoeven. A interligação do circuito baseada em lógica programada, utilizando CLP, com o circuito original baseado em lógica por fios, utilizando relés, pode ser verificada com maiores detalhes no Apêndice.

\subsubsection{Controlador remoto}

O hardware utilizado para o controlador remoto foi um microcomputador pessoal PC (Personal Computer) com processador Celeron da Intel, com freqüência de clock de $400 \mathrm{MHz}$, memória RAM (Random Access Memory) principal de 128 Mbytes, disco rígido com capacidade de 4 Gbytes, unidade de floppy disk de $3 \frac{1}{2}$ ”, unidade de CDROM (Compact Disc - Read Only Memory), placa de rede 10 Mbps e placa de fax/modem. Nessa plataforma foi instalado o sistema operacional Windows 2000 Professional Service Pack 2.

\subsection{Software}

O software do Agrilogic, devido às suas características intrínsecas e sua proximidade com o processo, foi dividido em dois grupos para efeitos de estudo e desenvolvimento. O primeiro grupo, denominado como supervisão e controle remoto, possui a função de um controle supervisório remoto, juntamente com uma 
IHM apropriada; e o segundo grupo, denominado como supervisão e controle local, possui a função de supervisão e controle de curto prazo, pois é o que está em contato com o processo, e não possui uma preocupação de uma IHM local.

\subsubsection{Supervisão e controle remoto}

O CLP não possui uma interface amigável de comunicação com o usuário, tanto para configuração como para fornecer informações sobre o processo, dificultando dessa forma a interpretação e a tomada de decisão por parte do usuário. Visando tornar o sistema mais acessível, existe um grupo de softwares com características peculiares para as funções de supervisão e controle, conhecidos como SCADA (Supervisory Control And Data Acquisition), os quais possuem uma IHM amigável, através de uma representação visual e intuitiva do processo. Esses softwares suportam vários tipos de CLPs e outras interfaces com o processo físico. Para o desenvolvimento do Agrilogic foi utilizado o software Elipse Windows da empresa Elipse Software Ltda.

Segundo Elipse (1999), o software Elipse Windows é totalmente configurável pelo usuário e permite monitorar as variáveis do processo em tempo real, através de gráficos e objetos que estão relacionados com as variáveis físicas, neste caso, da casa de vegetação. O software permite ainda realizar cálculos, criar bases de dados, relatórios, receitas e supervisionar e controlar a casa de vegetação a distância. O processo de supervisão e controle é realizado através de telas gráficas também chamadas de janelas, nas quais são dispostos os elementos denominados de objetos. Esses objetos podem ter uma associação com a variável física sob supervisão, e serem animados de acordo com o estado da variável física. Por exemplo, a animação do ventilador pode estar com suas hélices girando se a variável física associada a esta animação estiver ativa, ou pode estar com as hélices paradas, caso contrário. A esses objetos podem ser associados scripts (seqüências de instruções) que serão executados em função dos valores assumidos pelas variáveis supervisionadas.

A interligação do software Elipse Scada com o CLP é feita por meio de um software especial que possui a característica de se comunicar com um hardware específico. Esse software é conhecido como "driver". Para a comunicação com o CLP da empresa Klockner Moeller, o software da Elipse disponibiliza um driver denominado 
"Klockner.dll", o qual deve ser explicitamente declarado durante a configuração do software Elipse Scada. O CLP da Klockner Moeller possui uma região de memória RAM especial, denominada memória “marker". Ela é compartilhada através do driver com o software supervisório. Por exemplo, para se monitorar o sensor de temperatura Pt 100-1 da casa de vegetação, o CLP, após converter a grandeza analógica, coloca o valor binário em hexadecimal representativo dessa temperatura em uma posição de memória marker previamente declarada no programa do CLP. Essa posição de memória pode ser lida pelo software supervisório através do driver de comunicação. O mesmo princípio vale para o processo inverso, ou seja, no caso de se desejar enviar dados para o CLP. No presente texto a região de memória marker será referida como "variáveis de comunicação".

O driver permite a leitura dos seguintes tipos de variáveis pelo software supervisório:

- Bit - Utilizado principalmente para variáveis do tipo digital.

- Byte - Permite ler a parte superior ou inferior de uma palavra ( 2 bytes).

- Palavra simples (2 bytes).

- Palavra dupla (4 bytes).

- Ponto flutuante (4 bytes).

O driver não permite a escrita de variáveis do tipo byte, portanto não se pode escrever o byte superior e inferior de uma palavra de modo independente.

O Agrilogic foi projetado para conter uma janela principal e outras auxiliares. A partir da janela Principal pode-se navegar pelas janelas auxiliares através da seleção do botão correspondente. As janelas auxiliares são: Monitoração, Controle manual, Configurador de regras, Sincronismo, Gráficos e Alarmes. A partir da janela do configurador de regras, pode-se acessar as janelas de configuração dos algoritmos "single step" e "two step" para a temperatura e umidade. Os gráficos de temperatura, umidade e conjuntamente podem 
ser selecionados a partir da janela secundária Gráficos. O mapa de navegação do Agrilogic pode ser visto na figura 52.

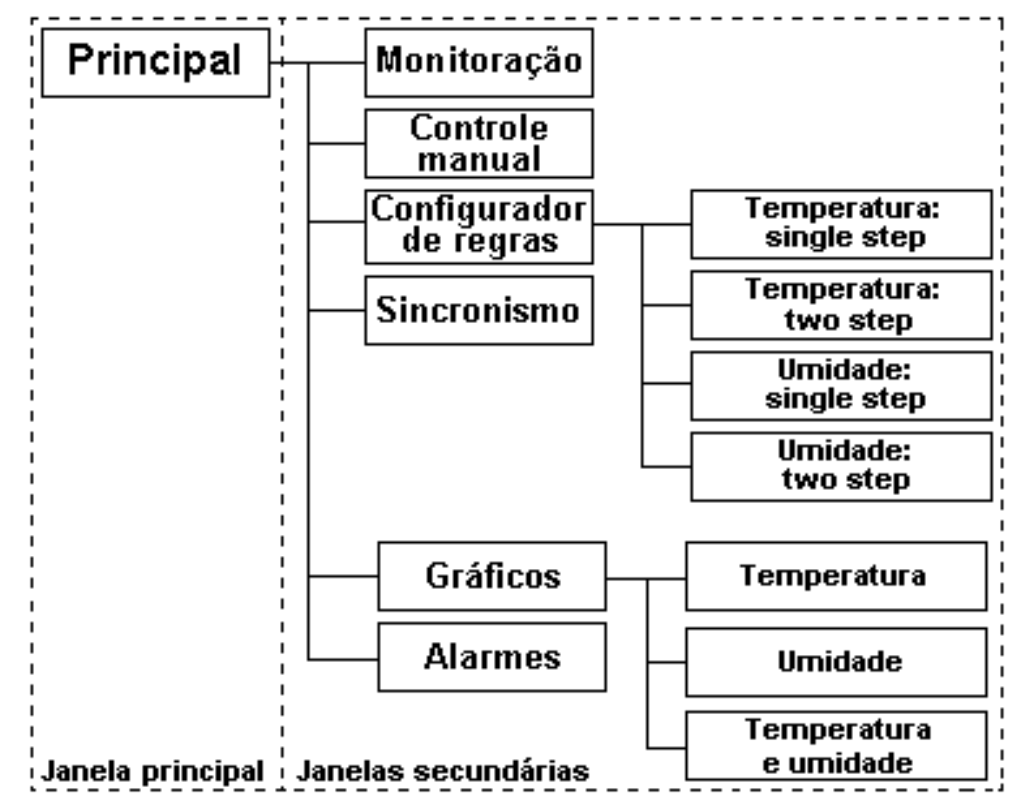

Figura 52 - Mapa de navegação do Agrilogic

As funcionalidades de cada janela do Agrilogic são descritas abaixo:

- Principal - É uma representação visual do processo da casa de vegetação e fornece as principais informações envolvidas no processo de uma forma sintetizada. A seguir são descritos os principais elementos da janela visualizados na figura 53.

No canto superior esquerdo, além da indicação da data e hora correntes, estão localizados dois objetos do tipo display, os quais permitem a visualização dos valores de referência (set points) previamente ajustados para as variáveis temperatura e umidade.

$\mathrm{Na}$ região inferior da janela existem duas linhas de status, uma para temperatura e outra para umidade. Essas linhas fornecem informações sobre os valores atuais das variáveis interna e externamente à casa de vegetação, qual variável tem prioridade de controle, qual algoritmo estará sendo utilizado para cada variável, e finalmente qual o valor máximo e mínimo permitido 
para a variável. Ainda na região inferior, existe um objeto do tipo botão, identificado pela palavra "Encerrar", que permite a finalização do programa Agrilogic.

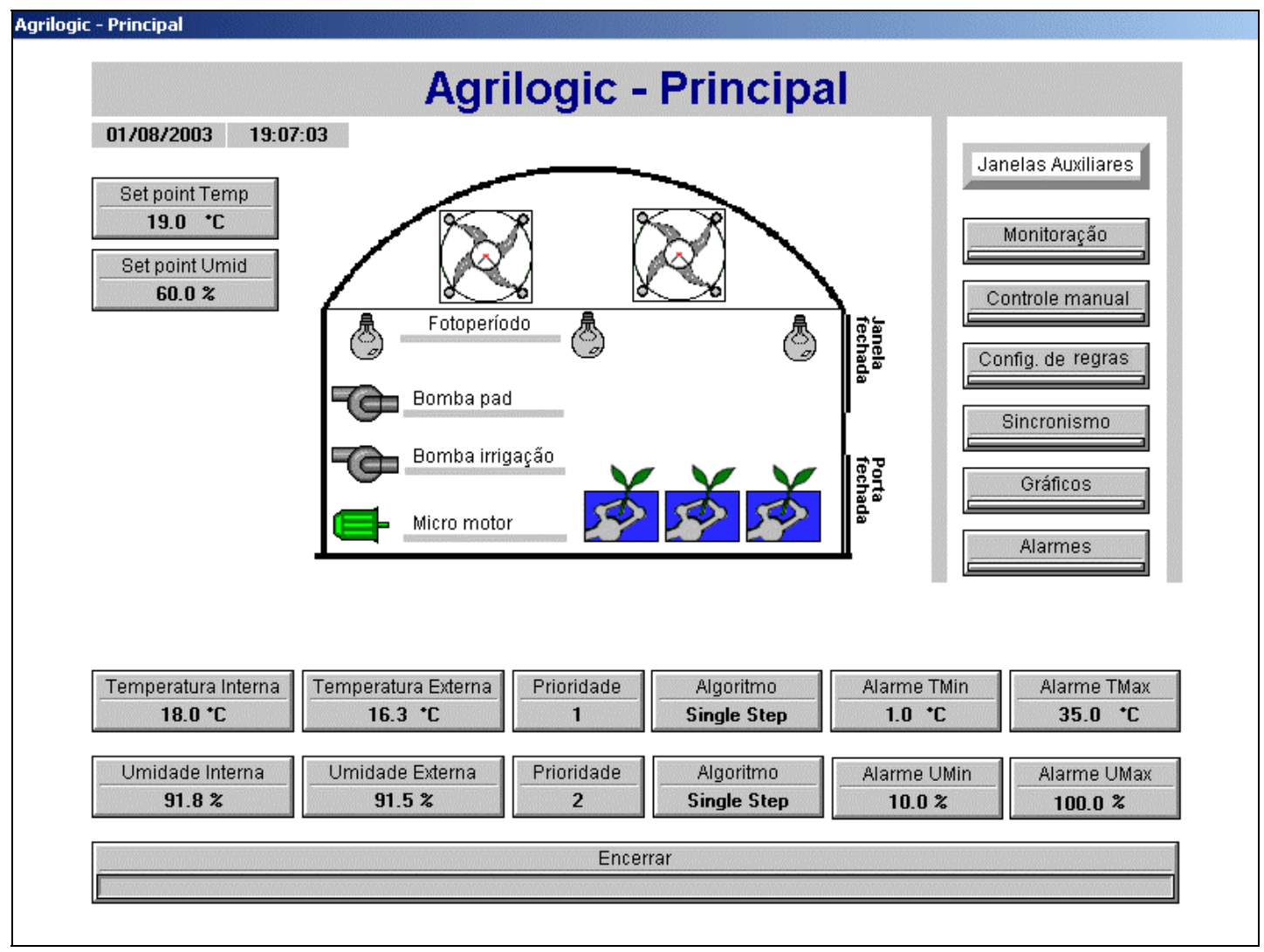

Figura 53 - Janela principal

No lado direito estão localizados seis objetos do tipo botão, que permitem acessar as janelas auxiliares: Monitoração, Controle manual, Configurador de regras, Sincronismo, Gráficos e Alarmes.

A região central possui o diagrama da casa de vegetação contendo os atuadores disponíveis para o controle das variáveis. Cada símbolo dos atuadores está associado com uma variável física, o que permite realizar a animação desses elementos. Os atuadores utilizados no processo possuem apenas duas situações: ligado e desligado. A animação dos atuadores é a seguinte: 
○ Ventiladores: Ligados - As hélices ficam girando. Desligados - As hélices ficam estáticas.

○ Bombas e motores: Ligados - Ficam alternando entre as cores verde e cinza, dando a sensação de pulsação. Desligados - Não existe a alternância de cores, ficando apenas a cor cinza.

○ Lâmpadas: Ligadas - ficam na cor amarela. Desligadas - ficam na cor cinza.

Existem, na lateral direita do diagrama da casa de vegetação, os símbolos de monitoração da porta e das janelas, sinalizando se as mesmas encontram-se fechadas ou abertas.

- Monitoração - Esta janela permite a visualização dos seguintes grupos de elementos:

- Entradas digitais - Monitoram os elementos que possuem apenas dois estados: ligado ou desligado ou ainda fechado ou aberto. Os elementos monitorados são: ventilador 1, ventilador 2, bomba pad, bomba de irrigação, micro motor, iluminação, porta de entrada e janelas.

- Saídas digitais - Controlam os elementos de atuação que possuem apenas dois estados: ligado ou desligado. Os elementos controlados são: ventilador 1 , ventilador 2 , bomba $p a d$, bomba de irrigação, micro motor e fotoperíodo.

- Entradas analógicas - Monitoram os sensores analógicos, ou seja, dois sensores de umidade interna EWHS-1 e EWHS-2, um sensor de umidade externa EWHS-3, quatro sensores de temperatura interna Pt 100-1, Pt 100-2, Pt 100-3 e Pt 100-4 e um sensor de temperatura externa Pt 100-5. Vide figura 54. 


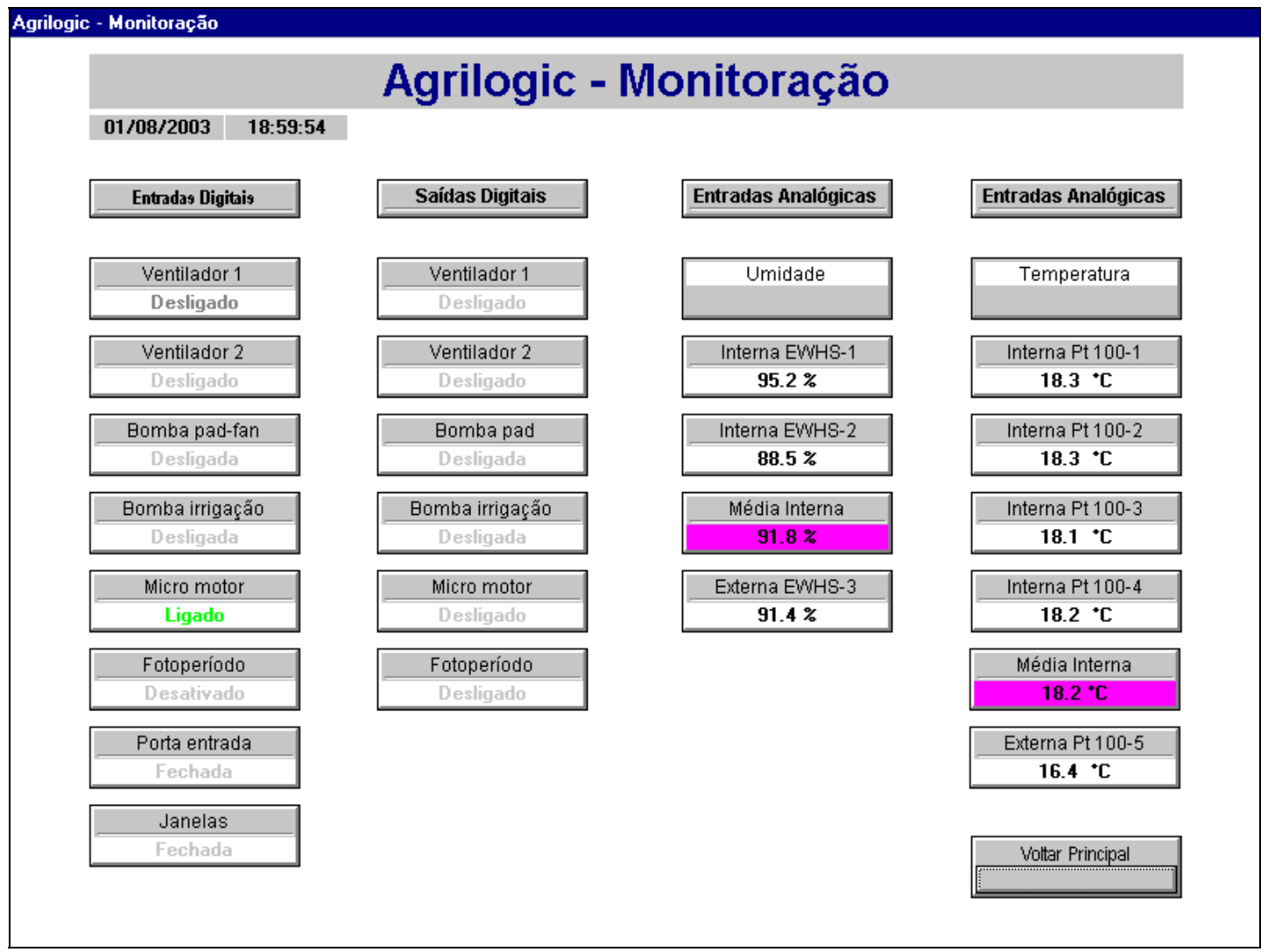

Figura 54 - Janela de monitoração

- Controle manual - Esta janela permite controlar os atuadores individualmente de forma manual, ou seja, desativando a característica do acionamento automático realizado pelos algoritmos do CLP. Essa característica é particularmente interessante para testes individuais dos atuadores. A animação utilizada para a visualização de funcionamento dos equipamentos nessa janela foi realizada pela utilização de cores associadas ao dispositivo. A cor cinza foi utilizada para indicar que o dispositivo está desligado, a cor verde foi utilizada para indicar que o dispositivo está ligado e a cor vermelha foi utilizada para sinalizar que ocorreu um defeito na ligação ou no desligamento do dispositivo. Por exemplo, emite-se o comando para ligar o ventilador-1 e, se o contato auxiliar do contator associado ao equipamento acionado não fornecer a informação correta, o desenho do ventilador será exibido na cor vermelha. Vide figura 55. 


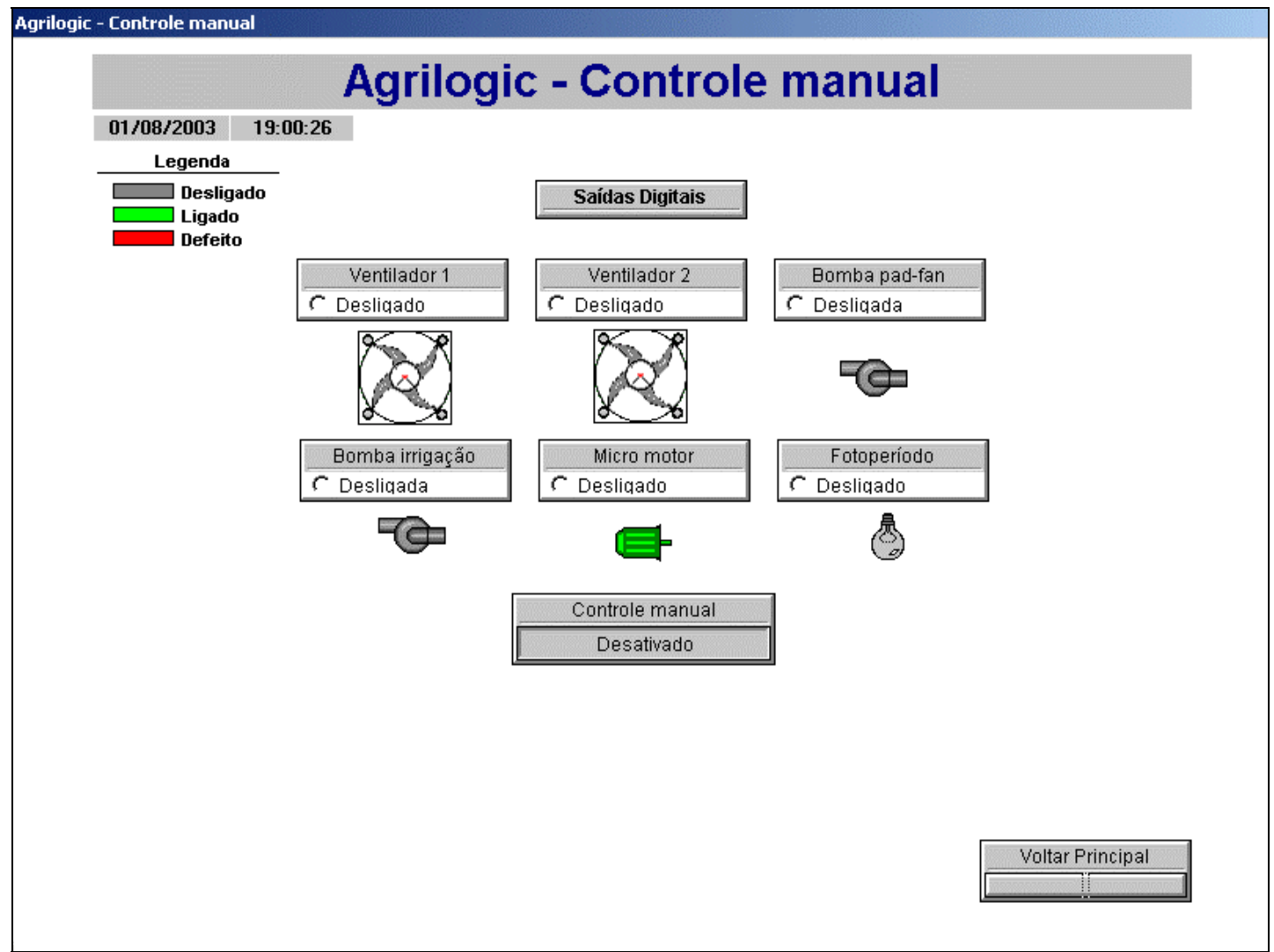

Figura 55 - Janela de controle manual

- Configurador de regras - Esta janela permite configurar as regras de controle das variáveis temperatura e umidade, ou seja, qual a prioridade e algoritmo de controle a ser utilizado para cada variável individualmente. Através dessa janela também é possível transferir os valores configurados para o CLP e salvá-los para futura utilização. Vide figura 56. 


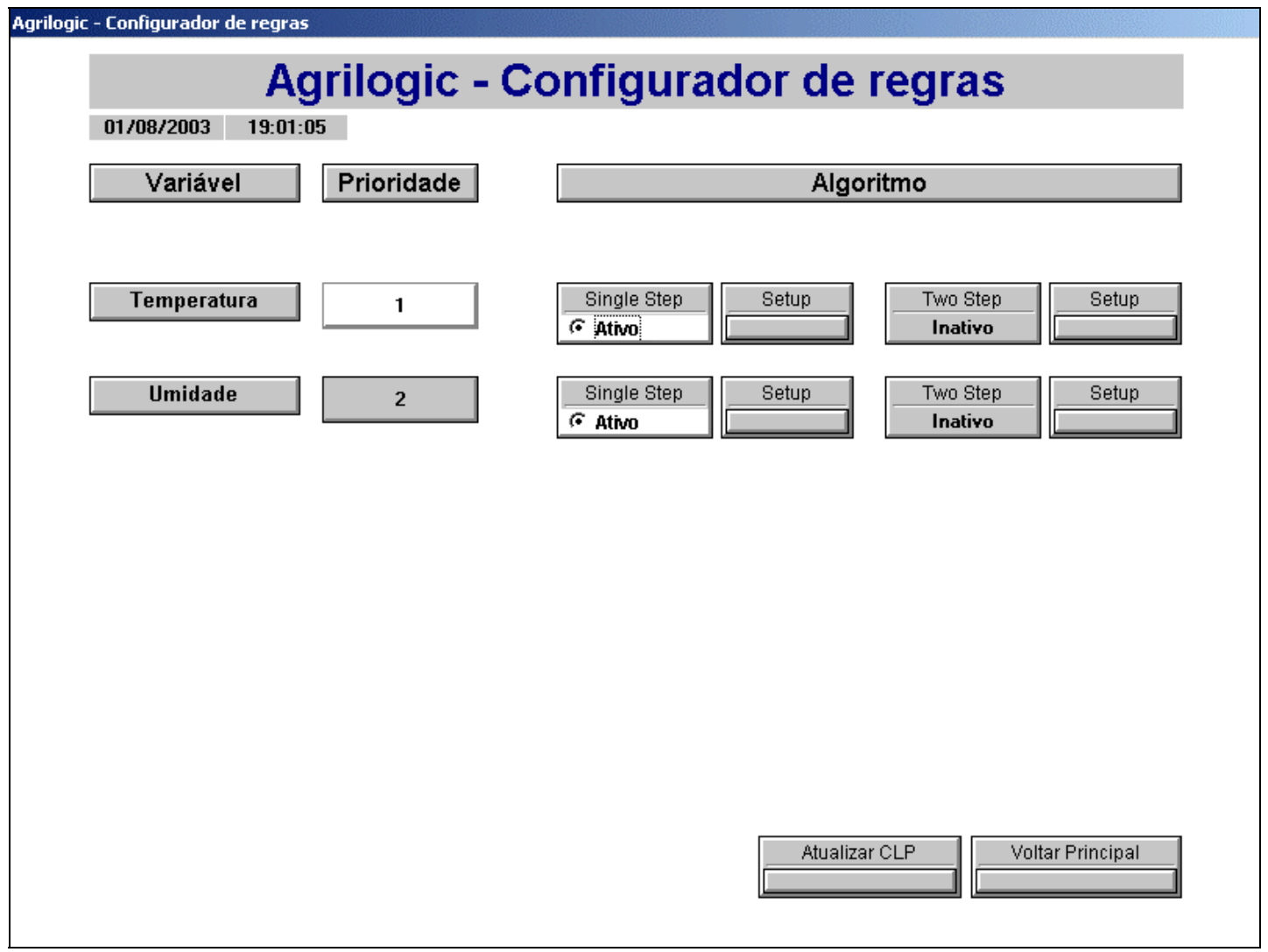

Figura 56 - Janela do configurador de regras

Existem dois algoritmos de controle para a variável temperatura.

○ Regra temperatura: "single step", permite a configuração do valor de referência (set point), do atraso (delay) e da duração do período de controle desejado em horas e minutos. É possível a configuração de até quatro períodos de controle distintos dentro do intervalo das 24 horas diárias. Esse algoritmo permite a monitoração da temperatura média interna da casa de vegetação e, caso ela ultrapasse o valor de referência, aciona os equipamentos necessários para o controle da mesma. Esse acionamento fica ativo pelo período definido pelo atraso, sendo que somente após atingir esse valor é que a temperatura será novamente avaliada. Esse procedimento é utilizado para se evitar a ação de se ligar e se desligar os equipamentos de forma freqüente, devido à oscilação da temperatura em torno do valor de referência, o 
que pode causar danos aos mesmos. Essa janela possibilita a verificação da consistência dos períodos programados através da transformação da duração de cada um períodos em minutos e através da soma desses períodos em minutos é feita a comparação com 1440 minutos, que é a duração total do período de um dia, ou seja, 24 horas. Essa janela possibilita também a verificação se os dados programados no controlador remoto são iguais aos dados transferidos para o controlador local, através da soma dos valores configurados em cada um dos controladores. A soma é efetuada pelo controlador remoto e também pelo controlador local, sendo que o resultado da soma feita pelo controlador local é transferido para o controlador remoto. O controlador remoto compara esses valores e se forem diferentes providencia a reprogramação do controlador local. Vide figura 57.

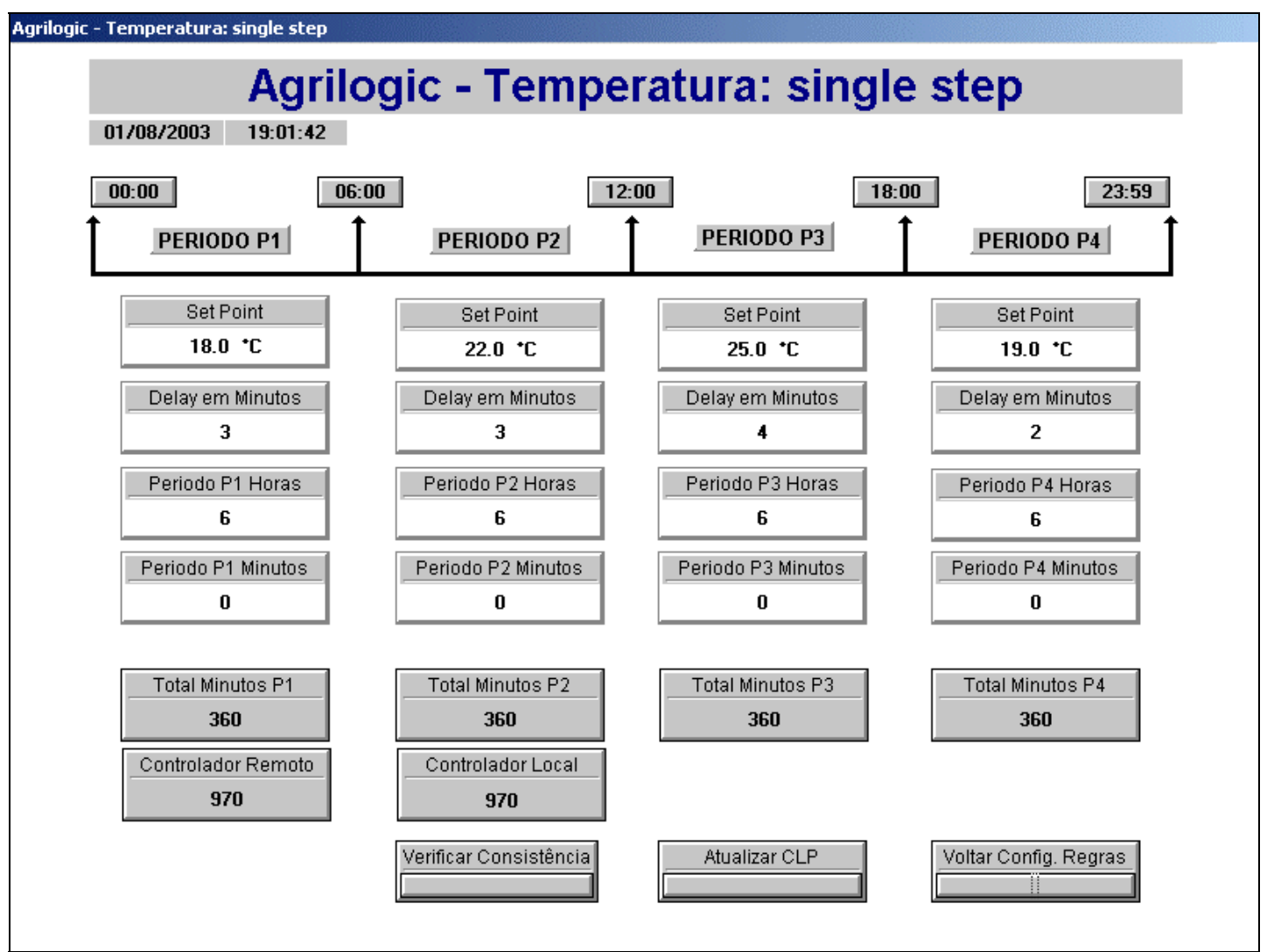

Figura 57 - Janela do configurador de regra de temperatura: single step 
Através dessa janela também é possível transferir os valores configurados para o CLP (controlador local), salvá-los para futura utilização ou ainda voltar para a janela do configurador de regras.

○ Regra temperatura: "two step", permite a configuração do valor de referência (set point), da faixa inferior, da faixa superior e da duração do período de controle desejado em horas e minutos. Dessa forma é possível se calcularem dois limites para a temperatura. A temperatura superior é calculada pela soma do valor de referência com o da faixa superior. A temperatura inferior é calculada pela diferença entre o valor de referência e o da faixa inferior. É possível a configuração de até quatro períodos distintos dentro do intervalo das 24 horas diárias. Esse algoritmo permite a monitoração da temperatura média interna da casa de vegetação e caso ela ultrapasse a temperatura superior, aciona os equipamentos necessários para o controle da mesma. Esse acionamento fica ativo até que o valor da temperatura caia abaixo da temperatura mínima. Esse procedimento é utilizado para se criar uma zona neutra que vai do limite inferior até o limite superior e desse modo evitar a ação de se ligar e se desligar os equipamentos de forma freqüente, devido à oscilação da temperatura em torno desses limites, o que pode causar danos aos equipamentos. Analogamente à janela do configurador de regra de temperatura "single step", essa janela permite ainda verificar a consistência dos períodos programados, se os dados programados no controlador remoto são iguais aos dados transferidos ao controlador local, transferência dos valores configurados para o CLP (controlador local), salvá-los para futura utilização ou ainda voltar para a janela do configurador de regras. Vide figura 58.

Esses dois algoritmos também estão disponíveis para o controle da umidade interna da casa de vegetação do IB-USP. 


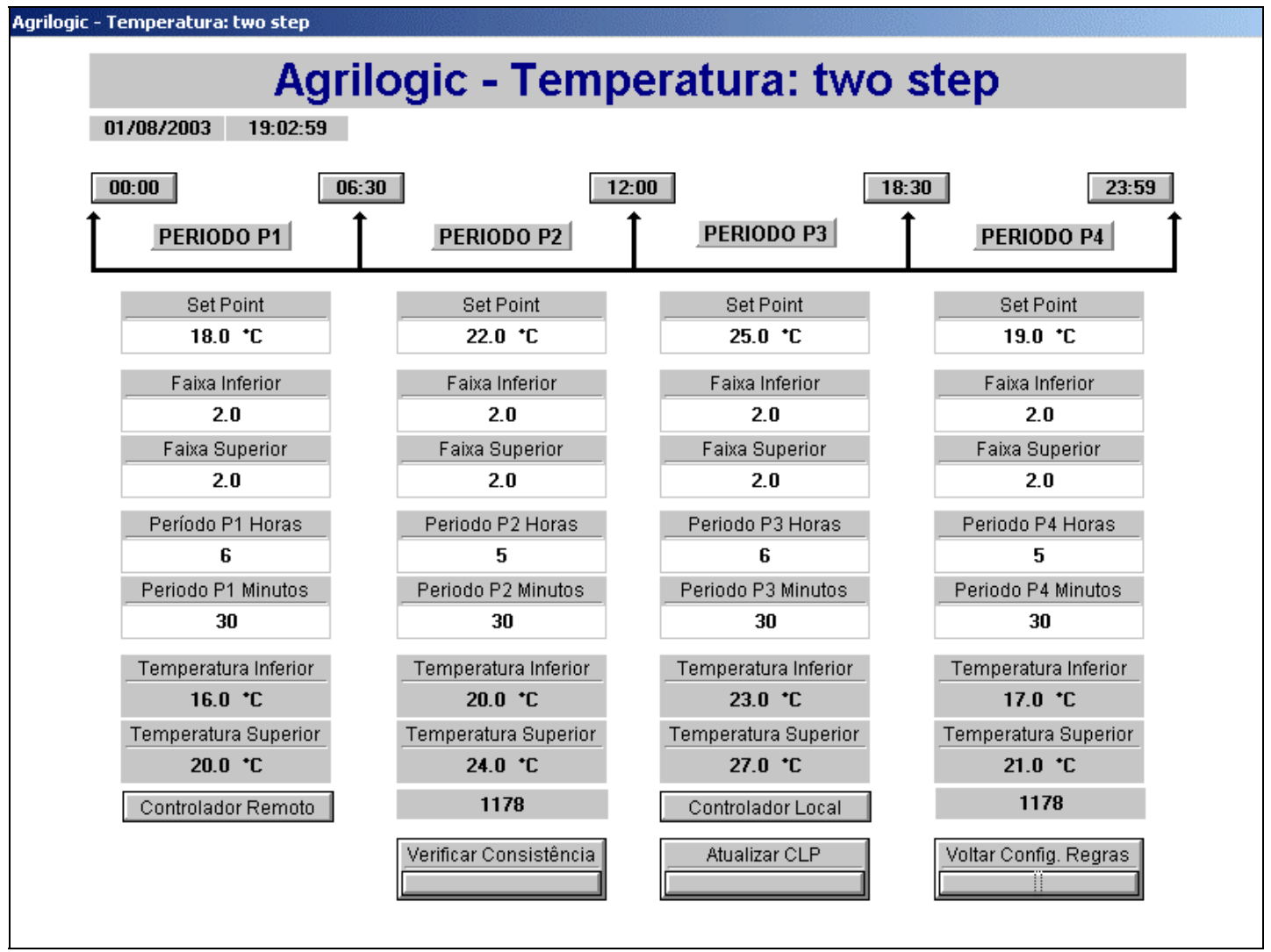

Figura 58 - Janela do configurador de regra de temperatura: two step

- Sincronismo - Em função da existência de dois relógios independentes, um no controlador local e outro no controlador remoto, torna-se necessário verificar o sincronismo desses relógios para se garantir o funcionamento dos algoritmos de acordo com os períodos programados. Essa janela, além de permitir a comparação da data e hora programadas nesses relógios, possibilita ainda configurar a data e hora do controlador local (CLP) com os mesmos valores da data e da hora do controlador remoto (computador de supervisão). Figura 59. 


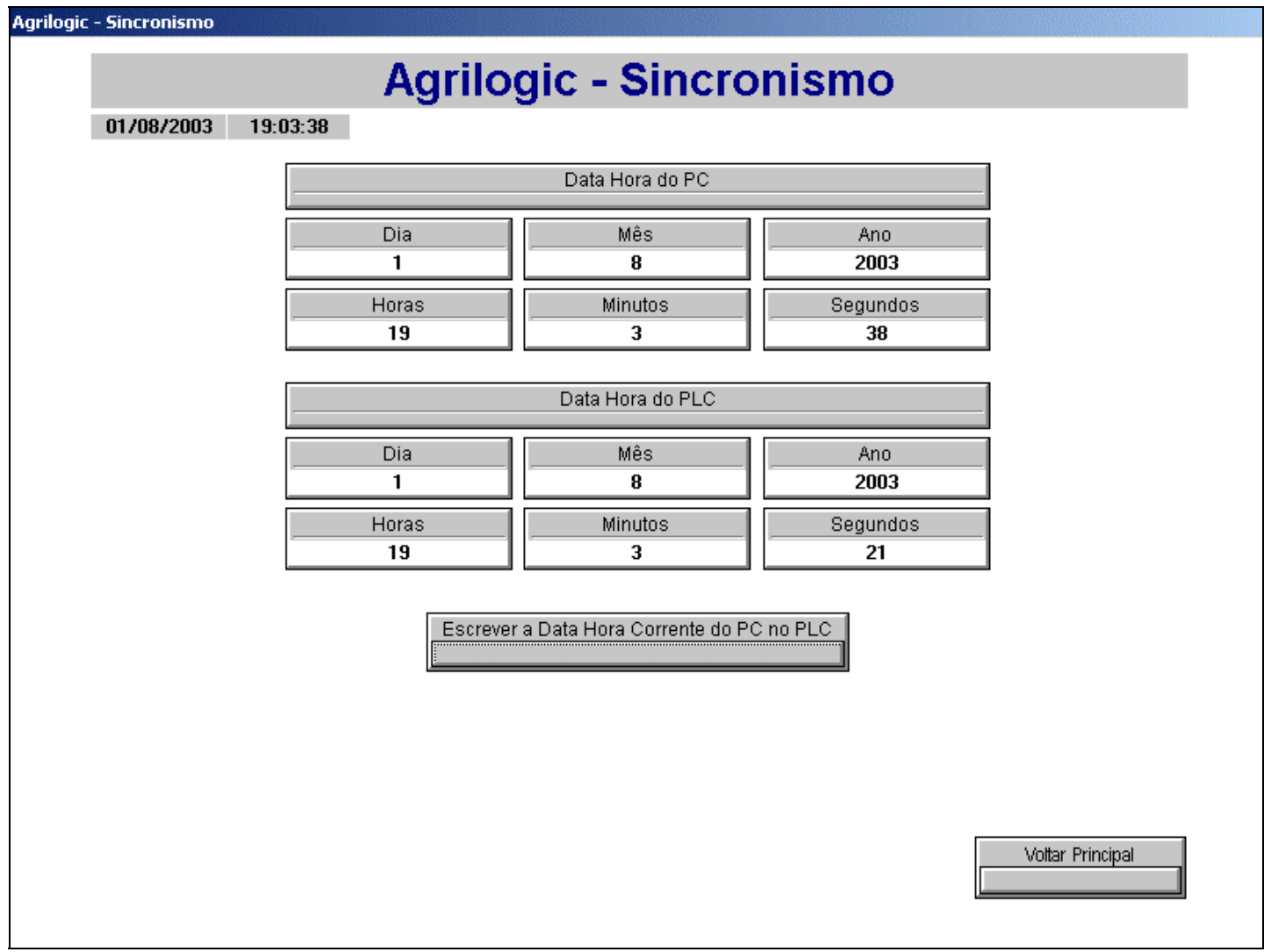

Figura 59 - Janela de sincronismo

- Gráficos - Essa janela permite a geração de gráficos para acompanhamento do comportamento da temperatura, da umidade e da temperatura média e da umidade média simultaneamente. Figura 60.

O gráfico das temperaturas interna e externa possibilita a visualização do comportamento dessa variável ao longo de um período pré-determinado, definido pelo usuário. Os gráficos de umidade e o de temperatura e umidade têm a mesma característica do gráfico de temperatura.

Os dados utilizados para a geração dos gráficos são obtidos a partir de um arquivo de histórico gerado pelo software de supervisão e controle. Esses dados são armazenados periodicamente com o intervalo de tempo configurável. No presente trabalho esse período foi ajustado para $10 \mathrm{~s}$. Figura 61. 


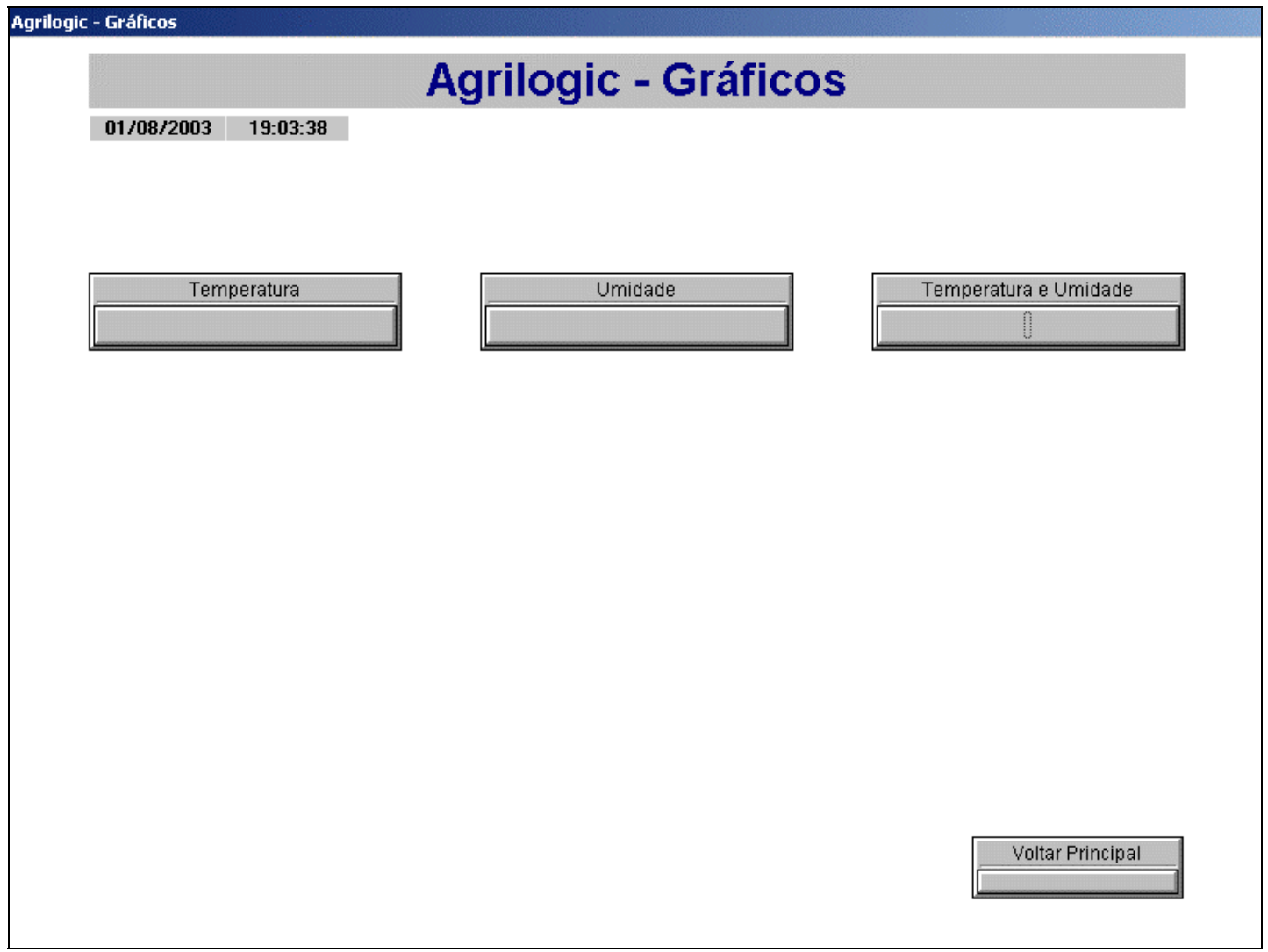

Figura 60 - Janela de gráficos

Com a finalidade de disponibilizar um conjunto de dados consistentes para análises posteriores, conforme as necessidades, cada registro desse arquivo contém os seguintes dados: dia, mês, ano, hora, minuto, segundo, temperatura do sensor Pt 100-1, temperatura do sensor Pt 100-2, temperatura do sensor Pt 100-3, temperatura do sensor Pt 100-4, temperatura do sensor Pt 100-5, temperatura média interna, valor de referência para a temperatura, faixa inferior da temperatura para o algoritmo "two step", faixa superior da temperatura para o algoritmo "two step", temperatura mínima do alarme, temperatura máxima do alarme, prioridade de controle da temperatura, algoritmo de controle da temperatura selecionado, período de controle da temperatura, umidade do sensor EWHS-1, umidade do sensor EWHS-2, umidade do sensor EWHS-3, umidade média interna, valor de referência para a umidade, faixa inferior da umidade para o algoritmo "two step", faixa superior da umidade para o algoritmo "two step", umidade mínima do alarme, 
umidade máxima do alarme, prioridade de controle da umidade, algoritmo de controle da umidade selecionado, período de controle da umidade, entrada ventilador 1, entrada ventilador 2, entrada bomba pad, entrada bomba de irrigação, entrada micro motor, entrada fotoperíodo, entrada porta, entrada janelas laterais, saída ventilador 1 , saída ventilador 2 , saída bomba pad, saída bomba de irrigação, saída micro motor, saída fotoperíodo, versão do software controlador local e versão do software controlador remoto.

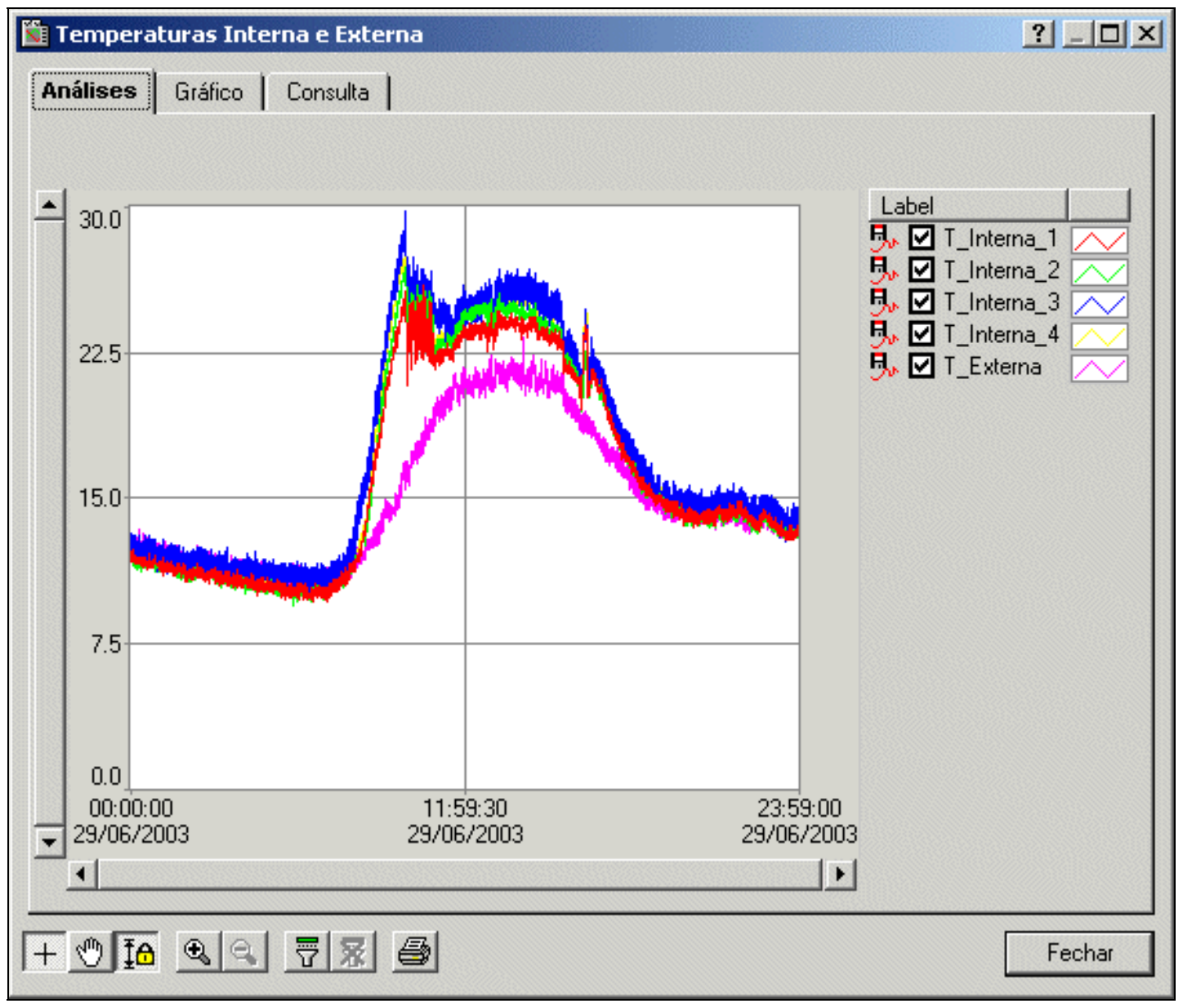

Figura 61 - Temperaturas interna e externa da casa de vegetação IB-USP

$\mathrm{O}$ arquivo de histórico pode ser exportado para um arquivo genérico no formato texto, que após tratamento adequado, pode ser importado por outros softwares comerciais, como por exemplo, a planilha eletrônica Excel da empresa Microsoft Corporation e o Matlab da empresa The MathWorks Inc. 
Essa conversão permite a análise dos dados de uma forma mais refinada por meio da utilização de ferramentas adequadas. Apenas para ilustrar a capacidade de análise proporcionada por essa base de dados e o software Matlab, é possível se verificar o comportamento da temperatura média interna em função do acionamento e desacionamento dos ventiladores de forma gráfica. Figura 62.

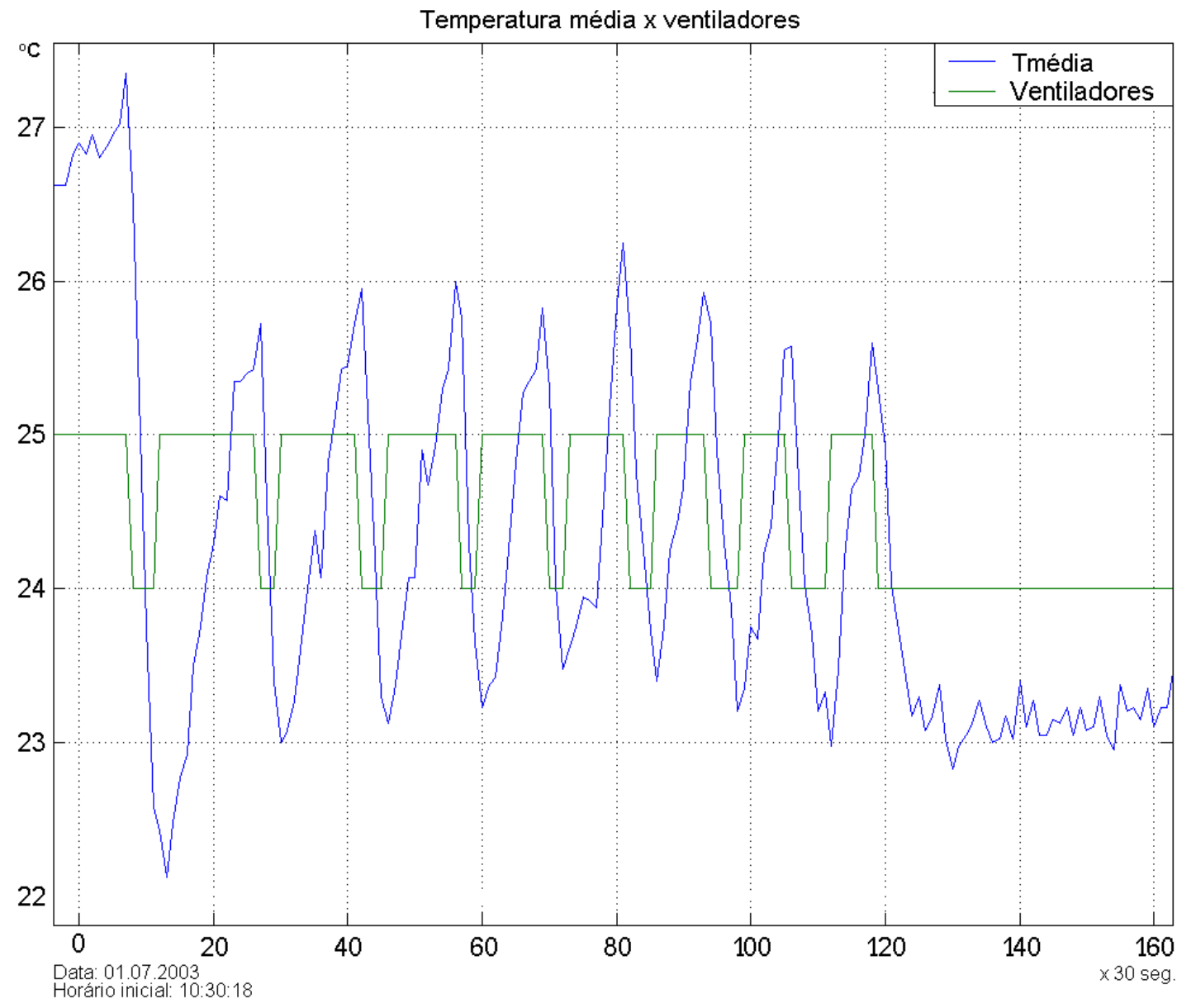

Figura 62 - Temperatura média em função do acionamento e desacionamento dos ventiladores

- Alarmes - Essa janela permite a configuração dos valores de alarme mínimos e máximos permitidos para a temperatura e umidade em cada período previamente selecionado, independentemente do algoritmo de controle utilizado. Quando ocorre a violação de quaisquer desses valores, é enviada uma mensagem para a janela do supervisório alertando ao operador 
que o limite crítico foi atingido. Essa janela permite ainda salvar esses parâmetros para futura utilização ou ainda voltar para a janela principal. Figura 63.

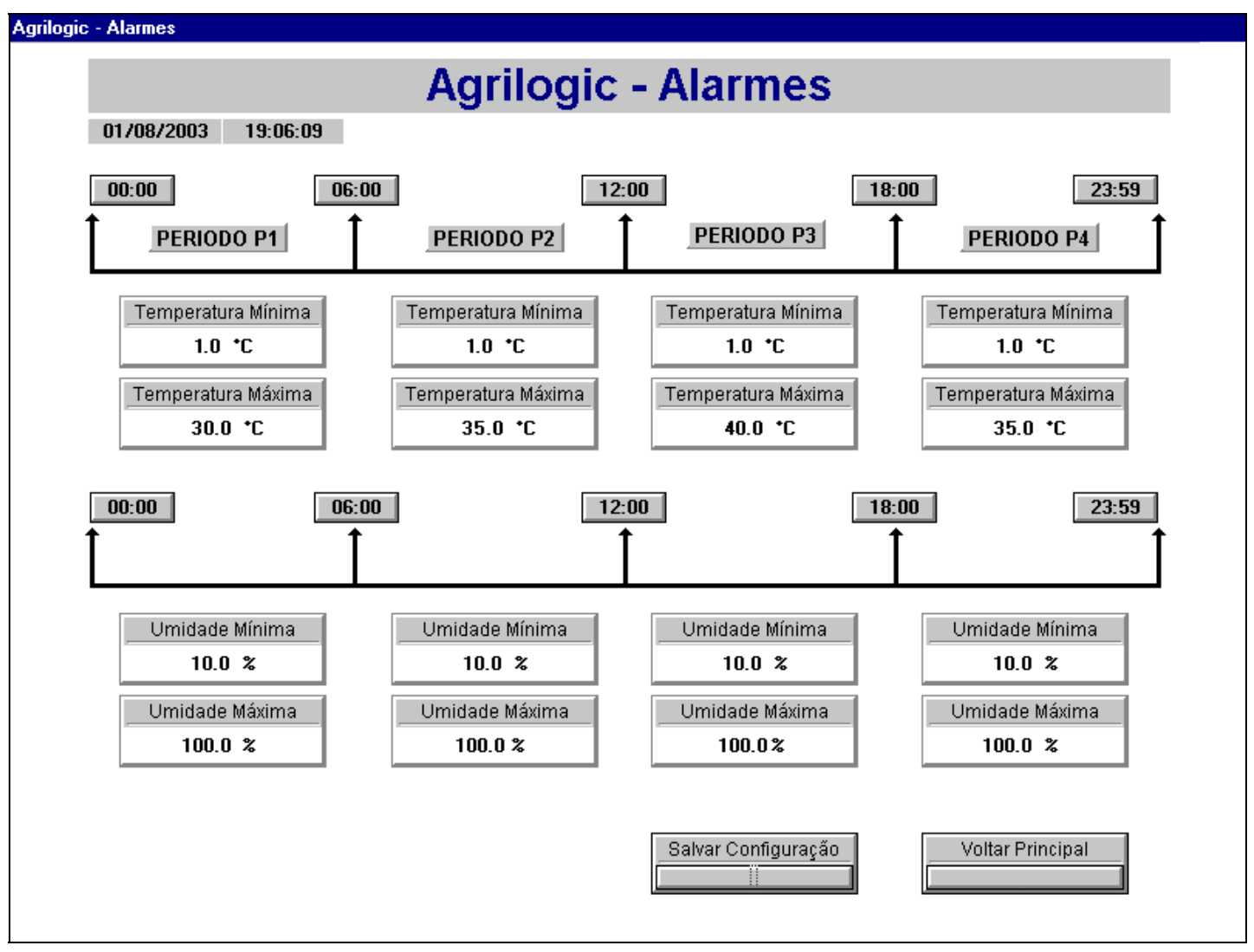

Figura 63 - Janela de alarmes

\subsubsection{Supervisão e controle local}

O software de supervisão e controle local do processo, feito para o CLP da Klockner Moeller, foi desenvolvido utilizando a ferramenta de desenvolvimento conhecida como Sucosoft S 40. Segundo Dielmann; Herrmann; Stammerjohann - a (1999), essa ferramenta de programação segue os padrões internacionais da norma IEC (International Electrotechnical Committee) 1131-3, fornecendo um conjunto de instruções em três tipos linguagens de programação; a programação por lista de instrução, a programação por diagrama de blocos e a programação por diagrama de relés. Para o presente trabalho foi utilizada a programação por lista de instrução 
devido a sua semelhança com a linguagem de montagem dos processadores Z80, de particular conhecimento do autor.

A documentação do sistema de desenvolvimento do Sucosoft S 40 é fundamentada em dois manuais, os quais serviram de subsídios para o desenvolvimento do presente trabalho. Segundo Dielmann; Herrmann; Stammerjohann - b (1999), o primeiro manual fornece a descrição completa do pacote de software, suas funções e também como utilizar as ferramentas fornecidas pelo Sucosoft S 40. Esse manual fornece informações sobre o sistema, o navegador, o editor, o configurador de topologia e os itens referentes a testes e comissionamento. Segundo Arndt; Herrmann; Kastner (2000), o segundo manual relaciona os elementos de linguagem necessários ao desenvolvimento do software, como declarações de variáveis, funções, blocos de funções e ainda as possíveis formas de programação textuais e gráficas.

A figura 64 representa o fluxograma do software do CLP, responsável pelo controle local do processo. No fluxograma, cada um dos retângulos, denominado de módulos, é identificado com um número seqüencial, cujas funcionalidades são descritas a seguir:

- Módulo 1 - Este módulo é responsável pela aquisição dos sinais dos sensores analógicos e digitais, como também a atualização das variáveis responsáveis pela comunicação com o software de supervisão e controle remoto. Como exemplo, pode-se citar a leitura do sensor de temperatura Pt 100-1 e a atualização da variável de comunicação com o valor lido.

- Módulo 2 - Este módulo é responsável pelo sincronismo do relógio do controlador local com o relógio do controlador remoto que está executando o software de supervisão e controle.

- Módulo 3 - Este módulo é responsável pelo controle manual dos equipamentos da casa de vegetação. Ele verifica os valores das variáveis de comunicação dos atuadores, configurados pelo software de supervisão e controle remotamente, e configura os atuadores conforme programado. 
- Módulo 4 - Este módulo é responsável pelo cálculo da média das duas umidades relativas internas da casa de vegetação. Os valores dos sensores EWHS-1 e EWHS-2 são somados e o resultado é dividido por dois, sendo o resultado final utilizado para a comparação com o valor de referência configurado para a umidade relativa interna.

- Módulo 5 - Este módulo é responsável pelo cálculo da média das quatro temperaturas internas da casa de vegetação. Os valores dos sensores Pt 100-1, Pt 100-2, Pt 100-3 e Pt 100-4 são somados e o resultado é dividido por quatro, sendo o resultado final utilizado para a comparação com o valor de referência configurado para a temperatura interna.

- Módulo 6 - Este módulo é responsável pela execução do algoritmo "single step" para a variável umidade. Este módulo compara o valor da média das duas umidades relativas internas com um valor de referência programado. Caso o valor da média esteja abaixo, os equipamentos de controle da umidade são acionados por um período mínimo em minutos previamente configurado. Somente após esse período é que a variável umidade será novamente avaliada.

- Módulo 7 - Este módulo é responsável pela execução do algoritmo "two step" para a variável umidade. Este módulo compara o valor da média das duas umidades relativas internas com os valores de referência programados, denominados de limite inferior e limite superior. Caso o valor da média esteja abaixo do limite inferior os equipamentos de controle da umidade são acionados e caso o valor da média esteja acima do limite superior os equipamentos de controle de umidade são desacionados. A diferença entre o limite superior e inferior é conhecida como zona neutra ou histerese, pois nessa faixa os estados dos equipamentos envolvidos não são alterados.

- Módulo 8 - Este módulo é responsável pela execução do algoritmo "single step" para a variável temperatura. Este módulo compara o valor da média das quatro temperaturas internas com um valor de referência programado. Caso o valor da média esteja acima, os equipamentos de controle da temperatura são 
acionados por um período mínimo em minutos previamente configurado. Somente após esse período é que a variável temperatura será novamente avaliada.

- Módulo 9 - Este módulo é responsável pela execução do algoritmo "two step" para a variável temperatura. Este módulo compara o valor da média das quatro temperaturas internas com os valores de referência programados, denominados de limite inferior e limite superior. Caso o valor da média esteja abaixo do limite inferior os equipamentos de controle da temperatura são desacionados e caso o valor da média esteja acima do limite superior os equipamentos de controle de umidade são acionados. A diferença entre o limite superior e inferior é conhecida como zona neutra ou histerese, pois nessa faixa os estados dos equipamentos envolvidos não são alterados.

- Módulo 10 - Este módulo é responsável pela atualização das variáveis de comunicação com o controlador remoto relativas à data e hora programadas no controlador local. Dessa forma é possível verificar remotamente a data e hora programada no CLP.

- Módulo 11 - Este módulo verifica os estados dos atuadores e atualiza as variáveis de comunicação com o software de supervisão e controle remoto relativas aos atuadores. Dessa forma é possível verificar remotamente o estado de cada equipamento da casa de vegetação. 


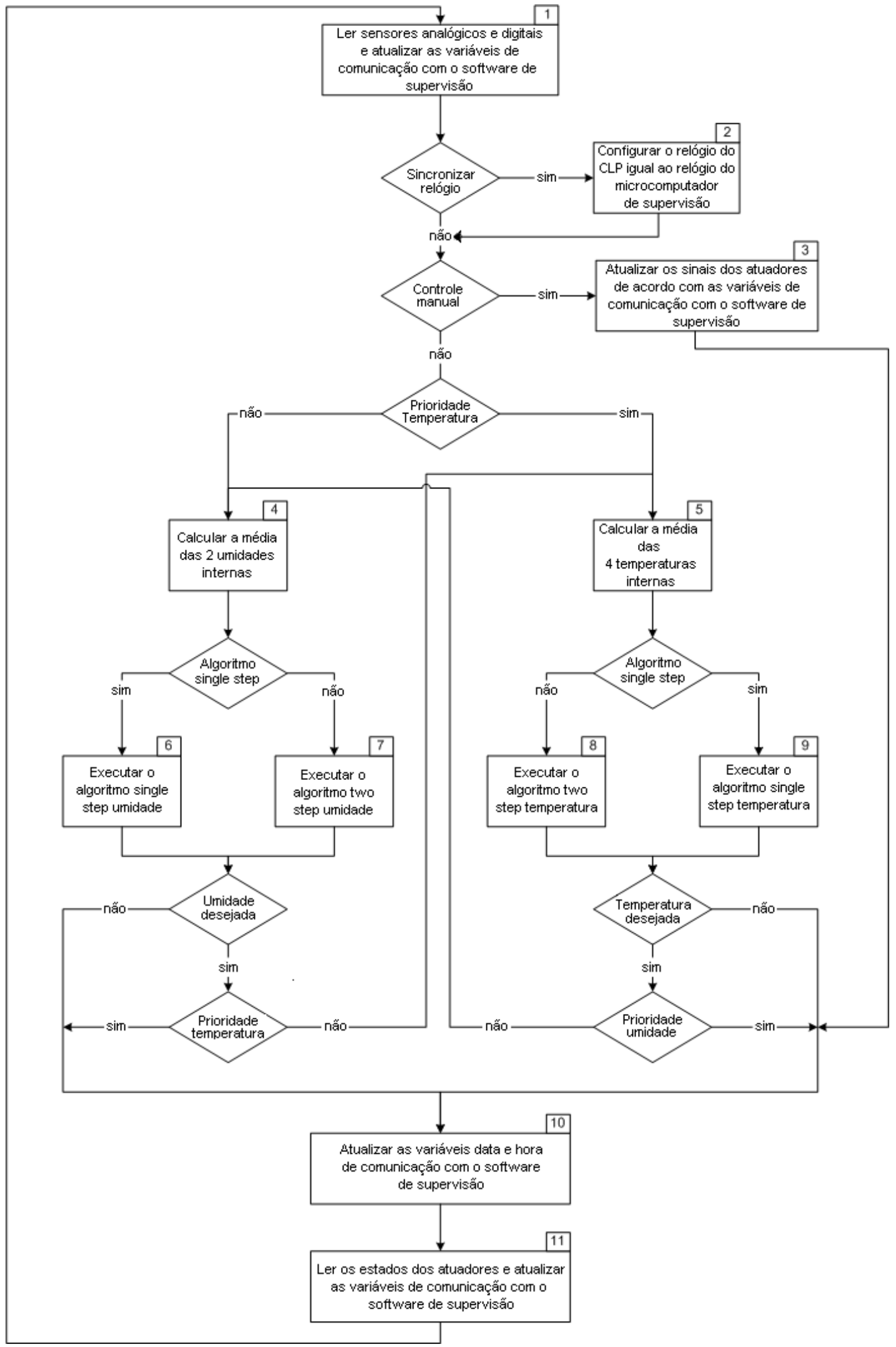

Figura 64 - Fluxograma do software de controle local do Agrilogic 


\subsection{Testes funcionais}

Com o objetivo de se avaliar o funcionamento do sistema, o Agrilogic foi dividido em quatro módulos funcionais: monitoração, atuação, controle local e controle remoto. Cada módulo foi testado de forma individual e ao final o sistema todo foi avaliado.

\subsubsection{Monitoração}

Esse módulo é responsável pela monitoração de todos os sensores envolvidos no sistema. Foram realizados testes de funcionamento para os sensores digitais e analógicos e também foi realizado o teste de aferição para os sensores analógicos.

- $\mathrm{O}$ teste de funcionamento dos sensores digitais foi realizado pelo acionamento e desacionamento individual dos equipamentos envolvidos. Foram acionados manualmente o ventilador 1, o ventilador 2, a bomba pad, a bomba de irrigação, o micro motor, as lâmpadas de fotoperíodo, a porta de entrada e as janelas laterais. Após o acionamento de cada equipamento, os sensores foram verificados através de indicação visual através de LEDs existentes no CLP e também na Janela de monitoração do Agrilogic.

- O teste de funcionamento dos sensores analógicos se limitou a verificar se os valores apresentados eram razoáveis ou não. O funcionamento desse módulo foi constatado por meio do Sucosoft, ferramenta de desenvolvimento de programa do CLP e também da Janela de monitoração do Agrilogic.

A tabela 3 resume os resultados obtidos dos testes funcionais do módulo de monitoração dos sensores digitais e analógicos.

Nesses testes pode-se constatar o comportamento razoável dos sensores de temperatura, fornecendo uma leitura média interna de $18,2{ }^{\circ} \mathrm{C}$, com uma temperatura externa menor, de $16,4{ }^{\circ} \mathrm{C}$. É normal a temperatura interna da estufa ser superior à temperatura externa. O sensor de umidade EWHS-2 apresentou um valor significativamente diferente dos outros dois, evidenciando um possível defeito ou um possível gradiente de umidade relativa na casa de vegetação. 
Tabela 3 - Resultados dos testes funcionais do módulo de monitoração

\begin{tabular}{|c|c|c|c|c|c|c|c|}
\hline \multicolumn{8}{|c|}{ Sensores } \\
\hline \multicolumn{4}{|c|}{ Digitais } & \multicolumn{4}{|c|}{ Analógicos } \\
\hline Ord. & Nome & Estado & \begin{tabular}{|l|} 
Resultado \\
\end{tabular} & Ord. & Variável & Nome & Resultado $^{(2}$ \\
\hline \multirow{2}{*}{1} & \multirow{2}{*}{ Ventilador 1} & Ligado & Ligado & \multirow{2}{*}{1} & \multirow{2}{*}{$\begin{array}{c}\text { Temperatura } \\
\text { interna }\end{array}$} & \multirow{2}{*}{$\begin{array}{c}\text { Pt } 100 \\
1\end{array}$} & \multirow{2}{*}{$18,3^{\circ} \mathrm{C}$} \\
\hline & & Desligado & Desligado & & & & \\
\hline \multirow{2}{*}{2} & \multirow{2}{*}{ Ventilador 2} & Ligado & Ligado & \multirow{2}{*}{2} & \multirow{2}{*}{$\begin{array}{c}\text { Temperatura } \\
\text { interna }\end{array}$} & \multirow{2}{*}{$\begin{array}{c}\text { Pt } 100 \\
2\end{array}$} & \multirow{2}{*}{$18,3^{\circ} \mathrm{C}$} \\
\hline & & Desligado & Desligado & & & & \\
\hline \multirow{2}{*}{3} & \multirow{2}{*}{ Bomba pad } & Ligada & Ligada & \multirow{2}{*}{3} & \multirow{2}{*}{$\begin{array}{c}\text { Temperatura } \\
\text { interna }\end{array}$} & \multirow{2}{*}{$\begin{array}{c}\text { Pt } 100 \\
3\end{array}$} & \multirow{2}{*}{$18,1^{\circ} \mathrm{C}$} \\
\hline & & Desligada & Desligada & & & & \\
\hline \multirow{2}{*}{4} & \multirow{2}{*}{$\begin{array}{l}\text { Bomba de } \\
\text { irrigação }\end{array}$} & Ligada & Ligada & \multirow{2}{*}{4} & \multirow{2}{*}{$\begin{array}{c}\text { Temperatura } \\
\text { interna }\end{array}$} & \multirow{2}{*}{$\begin{array}{c}\text { Pt } 100 \\
4\end{array}$} & \multirow{2}{*}{$18,2^{\circ} \mathrm{C}$} \\
\hline & & Desligada & Desligada & & & & \\
\hline \multirow{2}{*}{5} & \multirow{2}{*}{ Micro motor } & Ligado & Ligado $^{(1)}$ & \multirow{2}{*}{5} & \multirow{2}{*}{$\begin{array}{c}\text { Temperatura } \\
\text { externa }\end{array}$} & \multirow{2}{*}{$\begin{array}{c}\mathrm{Pt} 100 \\
5\end{array}$} & \multirow{2}{*}{$16,4^{\circ} \mathrm{C}$} \\
\hline & & Desligado & Desligado $^{(1)}$ & & & & \\
\hline \multirow{2}{*}{6} & \multirow{2}{*}{ Fotoperíodo } & Ligado & Ligado & \multirow{2}{*}{6} & Umidade & EWHS & 952 \\
\hline & & Desligado & Desligado & & interna & 1 & 95,2 \\
\hline 7 & Porta entrada & Aberta & Aberta & 7 & Umidade & EWHS & $88.5 \%$ \\
\hline & & Fechada & Fechada & & & 2 & \\
\hline 8 & Janelas & Aberta & Aberta & 8 & Umidade & EWHS & $4 \%$ \\
\hline & & Fechada & Fechada & & externa & 3 & \\
\hline
\end{tabular}

(1) Os testes foram realizados apenas com indicação visual através de LEDs, devido à inexistência de contator no circuito, elemento de manobra necessário para monitoramento e controle do micro motor.

(2) Valores não aferidos. Medidas efetuadas em 01/08/2003 às 19:00 h.

- O teste de aferição dos sensores analógicos foi realizado com o objetivo de se verificar se os valores fornecidos por esses sensores são aceitáveis ou não. Foram realizadas as aferições dos sensores de temperatura e umidade, utilizados na casa de vegetação, comparando os valores fornecidos pelos sensores analógicos com os valores fornecidos pelo sistema de medição de temperatura e umidade relativa, modêlo HOBO cedido pelo Laboratório de Abelhas, e pela estação meteorológica da USP. O HOBO não é um padrão de calibração e serve apenas para fornecer uma referência para o Agrilogic. Esse sistema é composto de dispositivos móveis de aquisição de dados e um software de controle. Os dispositivos possuem baterias próprias e permitem que sejam fixados próximos aos sensores sob avaliação. Após o período de avaliação os dispositivos são recolhidos e seus dados extraídos através de 
uma conexão RS-232 com o computador pessoal no qual está instalado o software de controle. Esse sistema permite a configuração de vários parâmetros de monitoração, sendo que, para o presente teste os principais parâmetros programados foram: a resolução, o horário de início e a freqüência de amostragem. A resolução selecionada foi alta, o horário de início sincronizado com o relógio do Agrilogic e o intervalo de aquisição dos dados foi selecionado para leitura de $10 \mathrm{em} 10 \mathrm{~s}$, sendo a mesma freqüência de amostragem utilizada pelo Agrilogic.

Devido à existência de apenas três dispositivos de aquisição de dados, eles foram dispostos na casa de vegetação de acordo com a figura 65 .

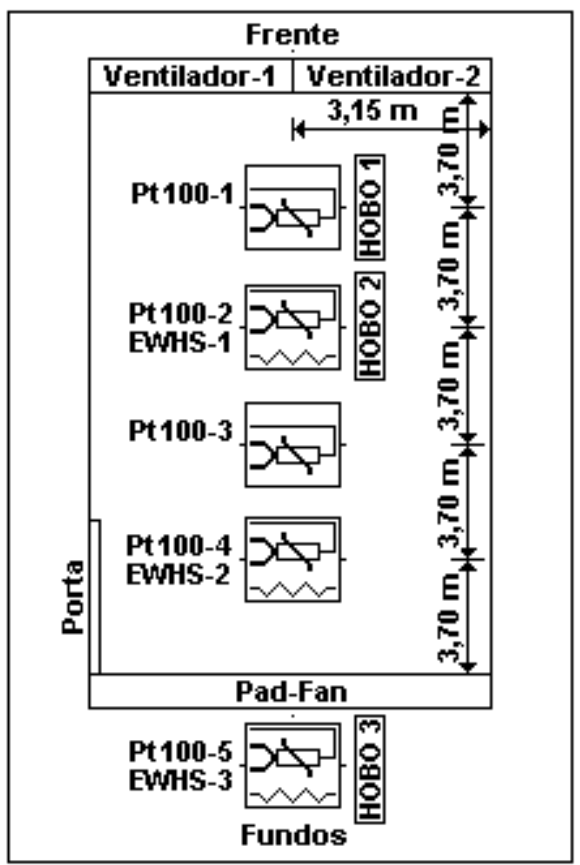

\section{Figura 65 - Distribuição dos dispositivos de aquisição de dados na casa de} vegetação do IB-USP

As especificações técnicas do HOBO são:

- Para medição de temperatura

Faixa de operação: $-30{ }^{\circ} \mathrm{C} \mathrm{a}+50{ }^{\circ} \mathrm{C}$. 
Exatidão: $\pm 0,2{ }^{\circ} \mathrm{C}$

Resolução: $0,02{ }^{\circ} \mathrm{C}$ (alta resolução - 12 bits quantização).

Tempo de resposta típico: 34 minutos.

○ Para medição de umidade

Faixa de operação: $0 \%$ a $100 \%$ umidade relativa.

Exatidão: $\pm 3 \%$.

Tempo de resposta típico: 30 minutos.

Deriva típico: $1 \%$ por ano.

Os dados da estação meteorológica foram obtidos por meio de um banco de dados disponível na página do WebBee (http://www.webbee.org.br) que é uma rede de informações sobre biodiversidade brasileira em abelhas nativas, desenvolvido pelo LAA e pelo Laboratório de Abelhas. As informações sobre temperatura e umidade são fornecidas em intervalos de 10 minutos, sendo necessária a interpolação dos dados para $0,1 \mathrm{~Hz}$, para ficar com a mesma base de tempo dos outros dois sistemas, o Agrilogic e o HOBO. Os dados da estação meteorológica foram utilizados para comparação da temperatura e umidade externa.

A figura 66 mostra o gráfico da aferição da temperatura interna e externa da casa de vegetação. Nesse gráfico são desenhadas as curvas da temperatura fornecida por cada sensor Pt 100, pelos dispositivos HOBO e pela estação meteorológica. O período de observação foi cuidadosamente selecionado visando evitar turbulências causadas pela ativação dos ventiladores, dessa maneira, a temperatura registrada pelos dois sistemas se comporta de maneira semelhante. A análise estatística das amostras de temperatura interna e externa foi realizada no intuito de se verificar se os sensores de temperatura apresentam características semelhantes. A tabela 4 resume os valores obtidos na análise. Como se pode verificar os sensores apresentam comportamento 
bem uniforme, sendo que a diferença dos valores médios de cada sensor não ultrapassa a soma dos erros intrínsecos dos sensores e do CLP que é de aproximadamente $\pm 0,8{ }^{\circ} \mathrm{C}$. A diferença acentuada entre os valores da temperatura externa, medidos pelo Agrilogic, pelo HOBO e pela estação meteorológica pode estar relacionada com a distância física e posicionamento entre os dois primeiros sistemas e a estação meteorológica.
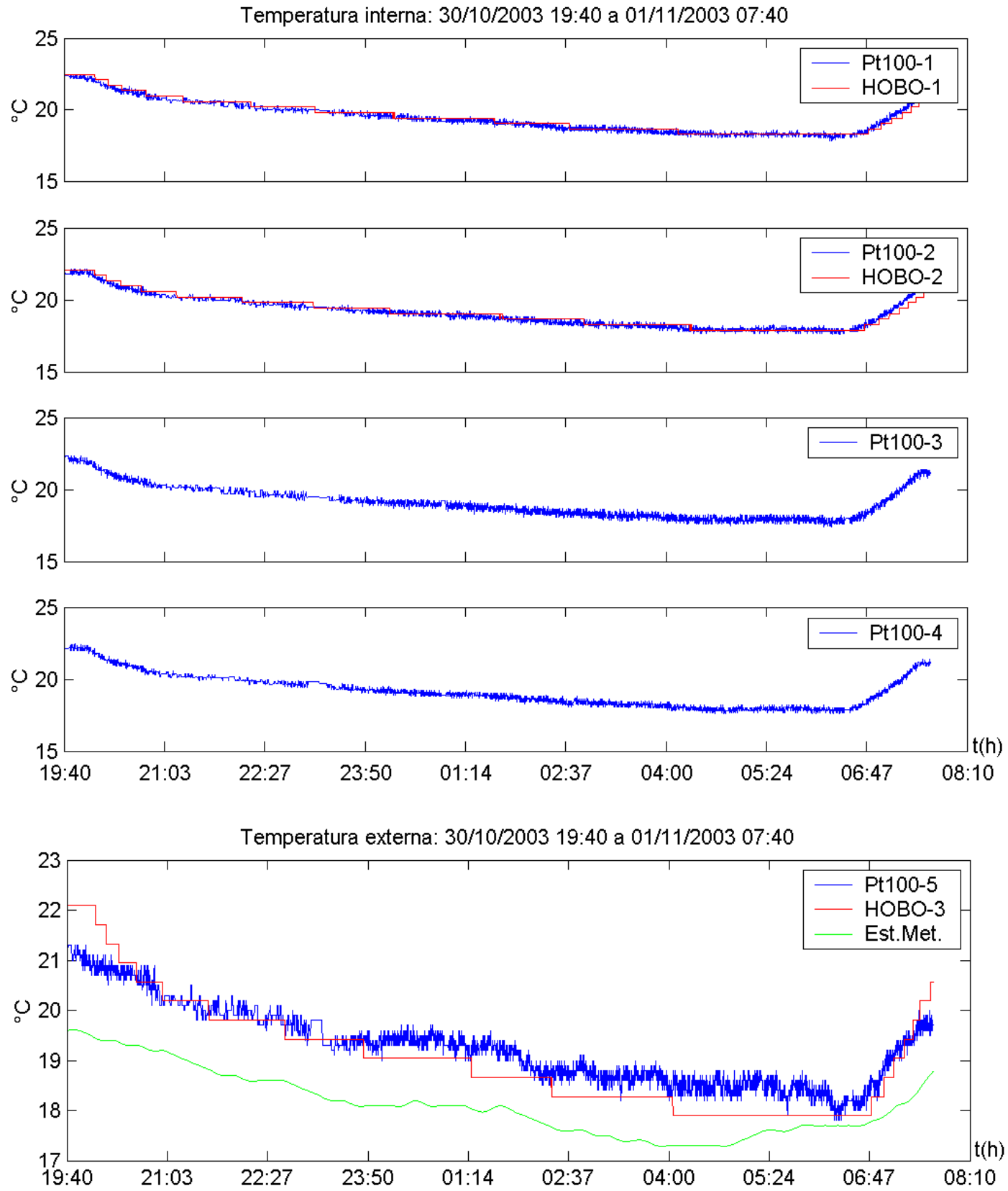

Figura 66 - Curvas de aferição da temperatura interna e externa da casa de vegetação do IB-USP 
Tabela 4 - Dados estatísticos das amostas da temperatura interna e externa da casa de vegetação do IB-USP

\begin{tabular}{|c|c|c|c|c|c|}
\hline \multicolumn{7}{|c|}{ Temperatura interna e externa $^{(\mathbf{1})}$} \\
\hline Sensor & $\begin{array}{c}\text { Média } \\
{ }^{\circ} \mathbf{C}\end{array}$ & $\begin{array}{c}\text { Mínima } \\
{ }^{\circ} \mathbf{C}\end{array}$ & $\begin{array}{c}\text { Máxima } \\
{ }^{\circ} \mathbf{C}\end{array}$ & $\begin{array}{c}\text { Amplitude } \\
{ }^{\circ} \mathbf{C}\end{array}$ & $\begin{array}{c}\text { Desvio } \\
\text { Padrão }\end{array}$ \\
\hline Pt 100-1 & 19,4700 & 17,80 & 22,40 & 4,60 & 1,0928 \\
\hline Pt 100-2 & 19,1139 & 17,60 & 22,10 & 4,50 & 1,0713 \\
\hline Pt 100-3 & 19,0996 & 17,40 & 22,30 & 4,90 & 1,1036 \\
\hline Pt 100-4 & 19,1752 & 17,60 & 22,50 & 4,90 & 1,1300 \\
\hline Pt 100-5 & 19,2787 & 17,80 & 21,40 & 3,60 & 0,7841 \\
\hline HOBO-1 & 19,5387 & 18,28 & 22,48 & 4,20 & 1,1314 \\
\hline HOBO-2 & 19,1700 & 17,90 & 22,09 & 4,19 & 1,1102 \\
\hline HOBO-3 & 19,0656 & 17,90 & 22,09 & 4,19 & 1,0875 \\
\hline Est.Met. & 18,1266 & 17,28 & 19,60 & 2,32 & 0,6428 \\
\hline
\end{tabular}

(1) Amostras colhidas no período das 19:40 horas do dia 31/10/2003 até 07:40 horas do dia 01/11/2003.

Para este teste da aferição da umidade interna e externa da casa de vegetação foram utilizados quatro dispositivos de aquisição de dados $\mathrm{HOBO}$, sendo necessário alterar a distribuição dos dispositivos de aquisição feita originalmente, conforme referenciado na figura 65 , sendo que o dispositivo HOBO-3 foi posicionado junto ao sensor EWHS-2 e o HOBO-4 foi posicionado junto ao EWHS-3. A figura 67 mostra o gráfico da aferição da umidade interna e externa da casa de vegetação. Nesse gráfico são desenhadas as curvas da umidade fornecida por cada sensor EWHS, pelos dispositivos HOBO e pela estação meteorológica. Pela análise das curvas pode-se verificar o comportamento indevido dos HOBO-1 e HOBO-2 para a umidade alta, visto que apresentam valores maiores que $100 \%$ de umidade relativa. Curiosamente nota-se que o conjunto EWHS-1 e HOBO-2 e o conjunto EWHS-2 e HOBO-3 alternam o comportamento por volta do valor de 50\% ocorrido por volta das 08:00 horas, sendo que o primeiro conjunto apresenta comportamento semelhante para umidades relativas baixas (menor que $50 \%$ ) e comportamento discrepante para umidades relativas altas (maior que $50 \%)$. 

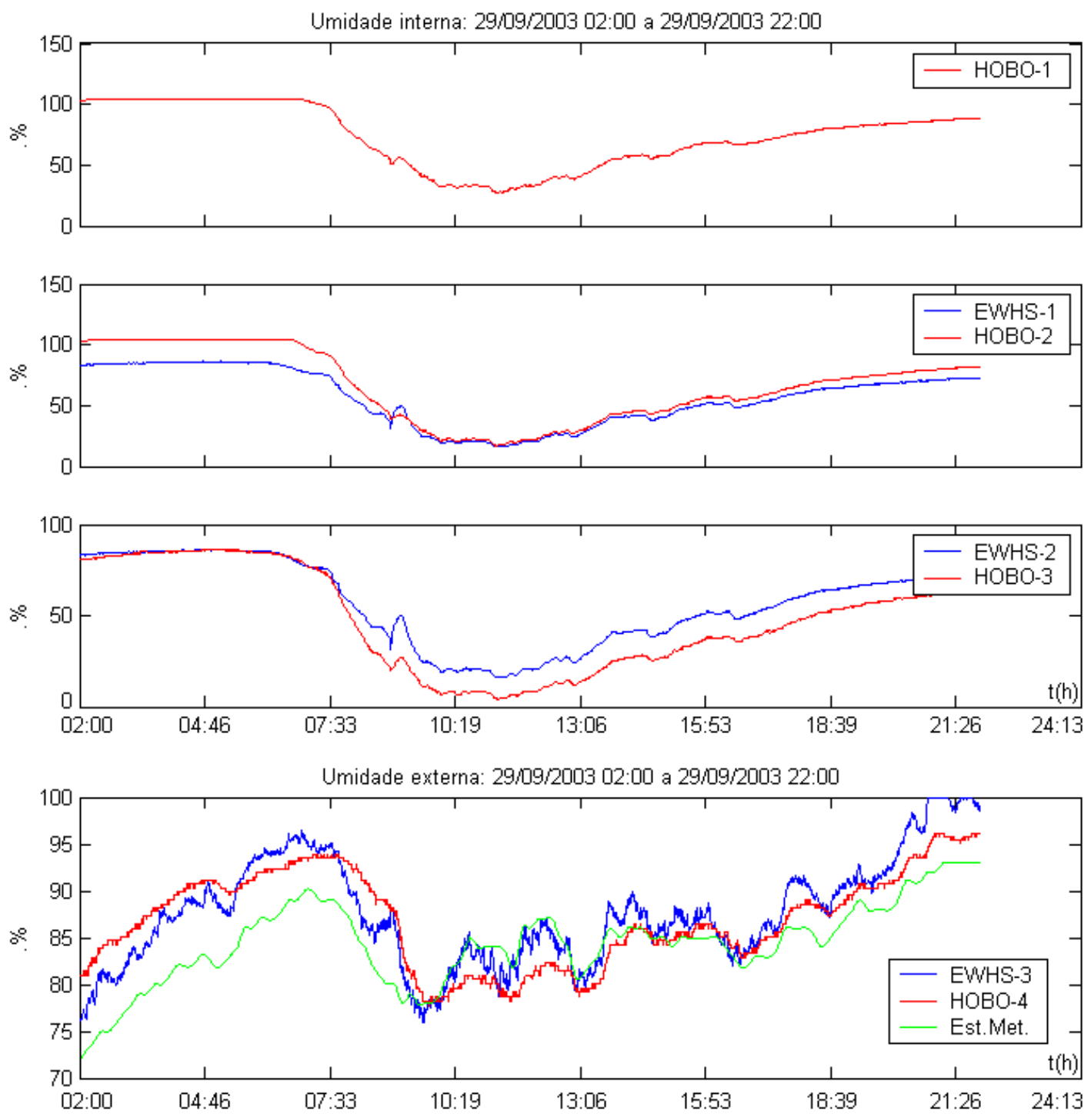

\section{Figura 67 - Curvas de aferição da umidade interna e externa da casa de vegetação do IB-USP}

A diferença acentuada entre os valores da umidade externa, medidos pelo Agrilogic, pelo HOBO e pela estação meteorológica, principalmente durante a madrugada, pode estar relacionada ao posicionamento dos dois primeiros sensores, que ficam relativamente próximos ao solo, no qual a umidade é maior.

A análise estatística das amostras de umidade interna e externa foi realizada no intuito de se verificar se os sensores de umidade apresentam características semelhantes. A tabela 5 resume os valores obtidos na análise. Pela análise dos 
dados da tabela, verifica-se um gradiente de umidade decrescente da frente aos fundos da casa de vegetação. $\mathrm{O}$ sistema $\mathrm{HOBO}$ apresentou uma média decrescente de $73,54 \%$ até $47,71 \%$ enquanto o Agrilogic, por meio dos sensores EWHS-1 e EWHS-2 apresentou uma média decrescente de 59,20\% até $56,81 \%$. Os dados obtidos podem ser considerados razoáveis, tendo em vista que o erro intrínseco dos sensores EWHS e do CLP é de $\pm 5,4 \%$ e o erro do HOBO é de $\pm 3 \%$ com deriva de $1 \%$ ao ano, podendo ocorrer diferenças de até $8,4 \%$ nos valores além da deriva anual.

Tabela 5 - Dados estatísticos das amostas da umidade interna da casa de vegetação do IB-USP

\begin{tabular}{|c|c|c|c|c|c|}
\hline \multicolumn{7}{|c|}{ Umidade interna e externa $^{(1)}$} \\
\hline Sensor & $\begin{array}{c}\text { Média } \\
\text { \% }\end{array}$ & $\begin{array}{c}\text { Mínima } \\
\text { \% }\end{array}$ & $\begin{array}{c}\text { Máxima } \\
\text { \% }\end{array}$ & $\begin{array}{c}\text { Amplitude } \\
\text { \% }\end{array}$ & $\begin{array}{c}\text { Desvio } \\
\text { Padrão }\end{array}$ \\
\hline EWHS-1 & 59,2049 & 19,56 & 88,18 & 68,62 & 21,7712 \\
\hline EWHS-2 & 56,8116 & 15,97 & 86,43 & 70,46 & 22,7739 \\
\hline EWHS-3 & 87,6566 & 75,95 & 99,98 & 24,03 & 5,6656 \\
\hline HOBO-1 & 73,5416 & 26,8 & 104,20 & 77,40 & 25,0256 \\
\hline HOBO-2 & 65,7953 & 16,60 & 103,90 & 87,30 & 29,0643 \\
\hline HOBO-3 & 47,7105 & 3,90 & 86,60 & 82,70 & 27,5656 \\
\hline HOBO-4 & 86,9858 & 77,70 & 96,20 & 18,50 & 4,9825 \\
\hline Est. Met. & 84,4381 & 72,00 & 93,09 & 21,09 & 4,2828 \\
\hline
\end{tabular}

(1) Amostras colhidas em 29/09/2003 no período das 02:00 até 22:00 horas.

\subsubsection{Atuação}

Esse módulo é responsável pelo acionamento de todos os equipamentos envolvidos no sistema. Cada equipamento foi acionado e desacionado a fim de se verificar seu funcionamento através da Janela de controle manual do Agrilogic. A ação de controle foi verificada localmente, observando-se o comportamento dos equipamentos. A tabela 6 resume os resultados obtidos. 
Tabela 6 - Resultados dos testes do módulo de atuação

\begin{tabular}{|c|l|l|l|}
\hline \multicolumn{4}{|c|}{ Equipamentos } \\
\hline Ordem & \multicolumn{1}{|c|}{ Nome } & \multicolumn{1}{|c|}{ Controle } & \multicolumn{1}{|c|}{ Estado } \\
\hline 1 & Ventilador 1 & $\begin{array}{l}\text { Acionado } \\
\text { Desacionado }\end{array}$ & $\begin{array}{l}\text { Acionado } \\
\text { Desacionado }\end{array}$ \\
\hline 2 & Ventilador 2 & $\begin{array}{l}\text { Acionado } \\
\text { Desacionado }\end{array}$ & $\begin{array}{l}\text { Acionado } \\
\text { Desacionado }\end{array}$ \\
\hline 3 & Bomba pad & $\begin{array}{l}\text { Acionada } \\
\text { Desacionada }\end{array}$ & $\begin{array}{l}\text { Acionada } \\
\text { Desacionada }\end{array}$ \\
\hline 4 & $\begin{array}{l}\text { Bomba de } \\
\text { irrigação }\end{array}$ & $\begin{array}{l}\text { Acionada } \\
\text { Desacionada }\end{array}$ & $\begin{array}{l}\text { Acionada } \\
\text { Desacionada }\end{array}$ \\
\hline 5 & Micro motor & $\begin{array}{l}\text { Acionado } \\
\text { Desacionado }\end{array}$ & $\begin{array}{l}\text { Acionado } \\
\text { Desacionado }\end{array}$ \\
\hline 6 & Fotoperíodo & $\begin{array}{l}\text { Acionado } \\
\text { Desacionado }\end{array}$ & $\begin{array}{l}\text { Acionado } \\
\text { Desacionado }\end{array}$ \\
\hline
\end{tabular}

(1) Os testes foram realizados apenas com indicação visual através de LEDs, devido à inexistência de contator no circuito, elemento de manobra necessário para monitoramento e controle do micro motor.

Utilizando-se os dados armazenados no arquivo de histórico do processo é possível a geração do gráfico da figura 68 , o qual permite a confirmação dos resultados da tabela 6 de uma maneira visual. Os dados utilizados para a geração do gráfico foram os sinais de comando enviados para acionar ou desacionar os equipamentos e os sinais de retorno fornecidos pelos contatos auxiliares dos contatores dos referidos equipamentos. Nesse ponto é interessante verificar o funcionamento do sinal de controle manual. Nos instantes em que o controle manual está ativo o estado de funcionamento dos equipamentos é imposto pelo sinal de controle associado ao mesmo e nos instantes em que o controle manual está inativo o estado de funcionamento dos equipamentos é imposto pelo algoritmo de controle selecionado em função das condições ambientais da casa de vegetação. 


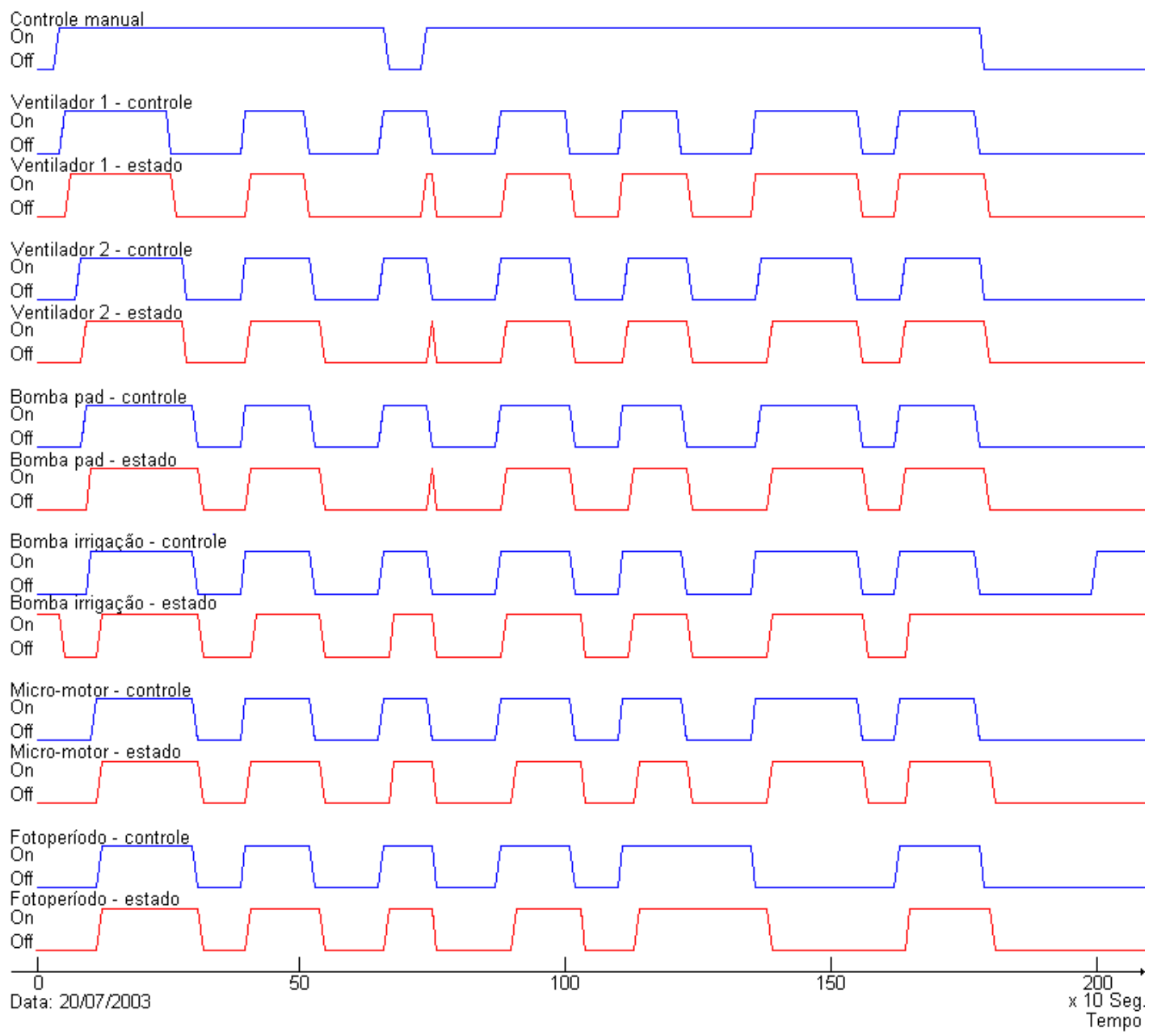

Figura 68 - Teste do módulo de atuação

\subsubsection{Controle local}

Esse módulo é responsável pela geração automática dos sinais de controle dos equipamentos envolvidos no sistema em função do valor médio das variáveis ambientais monitoradas e dos valores de referência configurados pelo controlador remoto. Cada um dos algoritmos, "single step" e "two step", foi testado por simulação devido à dificuldade de se reproduzirem as condições climáticas na casa de vegetação necessárias para os testes.

Todos os parâmetros necessários para a configuração dos quatro algoritmos implementados no controlador local foram fornecidos através da Janela 
Configurador de regras do Agrilogic. A tabela 7 resume os parâmetros configurados para os quatros algoritmos de controle implementados.

Tabela 7 - Parâmetros configurados para testes dos algoritmos "single step" e "two step"

\begin{tabular}{|c|c|c|c|c|}
\hline \multicolumn{5}{|c|}{ Parâmetros configurados } \\
\hline \multicolumn{5}{|c|}{ Single step temperatura } \\
\hline & \begin{tabular}{|l|l|l|} 
Período P1 \\
\end{tabular} & Período P2 & Período P3 & Período P4 \\
\hline Valor de referência $\mathrm{em}^{\circ} \mathrm{C}$ & 18 & 22 & 25 & 19 \\
\hline Atraso em minutos & 3 & 3 & 4 & 2 \\
\hline Intervalo em minutos & 360 & 360 & 360 & 360 \\
\hline \multicolumn{5}{|c|}{ Single step umidade } \\
\hline & Período P1 F & Período P2 & Período P3 & Período P4 \\
\hline Valor de referência em \% & 80 & 50 & 30 & 60 \\
\hline Atraso em minutos & 2 & 2 & 2 & 2 \\
\hline Intervalo em minutos & 360 & 360 & 360 & 360 \\
\hline \multicolumn{5}{|c|}{ Two step temperatura } \\
\hline & Período P1 & Período P2 & Período P3 & Período P4 \\
\hline Valor de referência $\mathrm{em}^{\circ} \mathrm{C}$ & 18 & 22 & 25 & 19 \\
\hline Faixa inferior em ${ }^{\circ} \mathrm{C}$ & 2 & 2 & 2 & 2 \\
\hline Faixa superior $\mathrm{em}^{\circ} \mathrm{C}$ & 2 & 2 & 2 & 2 \\
\hline Intervalo em minutos & 360 & 360 & 360 & 360 \\
\hline \multicolumn{5}{|c|}{ Two step umidade } \\
\hline & Período P1 & Período P2 & Período P3 & Período P4 \\
\hline Valor de referência em \% & 80 & 50 & 30 & 60 \\
\hline Faixa inferior em \% & 2 & 2 & 2 & 2 \\
\hline Faixa superior em \% & 2 & 2 & 2 & 2 \\
\hline Intervalo em minutos & 360 & 360 & 360 & 360 \\
\hline
\end{tabular}

A simulação foi realizada utilizando-se os dois potenciômetros P1 e P2 existentes no controlador compacto PS4-201-MM1. O potenciômetro P1 foi utilizado para emular a variável temperatura média interna e o potenciômetro P2 foi utilizado para emular a variável umidade média interna. Através da alteração do valor da resistência dos potenciômetros é possível simular as condições climáticas no interior da casa de vegetação. Os seguintes resultados foram observados. 
- Algoritmo "single step" para controle da temperatura - Para cada período configurado, o potenciômetro P1 foi ajustado para valores próximos ao valor de referência, observando o correto funcionamento do algoritmo. Por exemplo: o período P1 que foi configurado entre 24:00 e 06:00 horas e possui um valor de referência de $18{ }^{\circ} \mathrm{C}$ com atraso de 3 minutos. O potenciômetro P1 foi ajustado com valores inferiores ao valor de referência não sendo observada a ativação dos ventiladores. Quando o potenciômetro P1 foi ajustado ligeiramente acima do valor de referência observou-se a ativação dos ventiladores por um período mínimo de 3 minutos conforme configurado.

- Algoritmo "single step" para controle da umidade - Para cada período configurado, o potenciômetro P2 foi ajustado para valores próximos ao valor de referência, observando o correto funcionamento do algoritmo. Por exemplo: o período P1 que foi configurado entre 24:00 e 06:00 horas e possui um valor de referência de 80 \% com atraso de 2 minutos. O potenciômetro P2 foi ajustado com valores superiores ao valor de referência não sendo observada a ativação da bomba de irrigação e nem da bomba pad. Quando o potenciômetro P2 foi ajustado ligeiramente abaixo do valor de referência observou-se a ativação das bombas por um período mínimo de 2 minutos conforme configurado.

- Algoritmo "two step" para controle da temperatura - Para cada período configurado, o potenciômetro P1 foi ajustado para valores próximos ao valor de referência, observando o correto funcionamento do algoritmo. Por exemplo: o período P1 que foi configurado entre 24:00 e 06:00 horas e possui um valor de referência de $18{ }^{\circ} \mathrm{C}$ com uma faixa inferior de $2{ }^{\circ} \mathrm{C}$ e uma faixa superior de $2{ }^{\circ} \mathrm{C}$. O potenciômetro $\mathrm{P} 1$ foi ajustado com valores inferiores ao valor de referência superior de $20{ }^{\circ} \mathrm{C}$, não sendo observada a ativação dos ventiladores. Quando o potenciômetro P1 foi ajustado ligeiramente acima do valor de referência superior observou-se a ativação dos ventiladores. Para qualquer valor ajustado no potenciômetro P1 para valores acima do valor de referência inferior de $16{ }^{\circ} \mathrm{C}$ não foi observada a desativação dos ventiladores. 
Quando o potenciômetro foi ajustado ligeiramente abaixo desse valor observou-se a desativação dos ventiladores.

- Algoritmo "two step" para controle da umidade - Para cada período configurado, o potenciômetro P2 foi ajustado para valores próximos ao valor de referência, observando o correto funcionamento do algoritmo. Por exemplo: o período P1 que foi configurado entre 24:00 e 06:00 horas e possui um valor de referência de $80 \%$ com uma faixa inferior de $2 \%$ e uma faixa superior de 2 \%. O potenciômetro P2 foi ajustado com valores superiores ao valor de referência inferior de $78 \%$, não sendo observada a ativação das bombas pad e de irrigação. Quando o potenciômetro P2 foi ajustado ligeiramente abaixo do valor de referência inferior observou-se a ativação das bombas. Para qualquer valor ajustado no potenciômetro P2 para valores abaixo do valor de referência superior não foi observada a desativação das bombas. Quando o potenciômetro foi ajustado ligeiramente acima desse valor ( $82 \%$ ) observou-se a desativação das bombas.

Durante as realizações desses testes foram realizadas as verificações de prioridades programadas dos algoritmos, pois na configuração das regras de controle é necessário configurar a variável prioritária para controle, sendo que a segunda variável só será avaliada para efeito de controle se as condições configuradas para a primeira forem satisfeitas. Observou-se que somente quando as condições da variável prioritária estavam satisfeitas e que eram verificadas as condições da outra variável.

\subsubsection{Controle remoto}

Esse módulo é responsável pelo fornecimento de informações sobre o processo através do controle supervisório e aquisição de dados remotamente. Esse módulo foi utilizado no auxílio dos testes anteriormente descritos, ou seja, o de monitoração, atuação e controle local. Por meio deste módulo foi possível verificar os estados das variáveis envolvidas no sistema, gerar os sinais desejados para o controle manual dos atuadores, configurar os valores de referência dos algoritmos a serem executados pelo controlador local e ainda armazenar os dados necessários para análise futura e geração de alguns dos gráficos vistos. 
Adicionalmente às atividades de verificação do funcionamento do controlador remoto, foram realizados os testes de sincronismo dos relógios dos controladores remoto e local e do funcionamento da janela auxiliar de alarme, por meio da configuração de valores escolhidos de forma conveniente.

Foi realizado também o teste de verificação de recuperação da conexão telefônica em caso de queda da comunicação entre os controladores remoto e local. Para a realização deste teste, a conexão entre os controladores foi interrompida propositalmente, sendo verificado que após o período programado a reconexão foi realizada automaticamente pelo controlador remoto.

\subsection{Observações complementares}

Durante a realização do presente trabalho, mais especificamente durante a montagem e testes de validação do sistema Agrilogic, pôde-se verificar alguns pontos importantes:

- Necessidade de correção da tensão de alimentação do CLP para 24 VDC por meio da utilização de reguladores de voltagem 7824, pois, sendo a casa de vegetação alimentada por circuito trifásico com tensão nominal de aproximadamente 230 VAC (Voltage Alternate Current) e o armário do CLP especificado para circuito monofásico com tensão de alimentação de 110 VAC, ocasionou a elevação da tensão DC fornecida pela fonte serial que alimenta o CLP para aproximadamente $30 \mathrm{VDC}$, que é a máxima tensão de alimentação permitida pelo CLP. Devido à fonte ser serial, o sinal de saída acompanha as variações do sinal de entrada podendo ser prejudicial ao circuito do CLP.

- Necessidade da implementação de um algoritmo de recuperação automática da conexão da linha telefônica devido à ocorrência de perdas ocasionais.

- Necessidade da instalação de resistores fixos nas entradas de temperatura não utilizadas dos módulos de expansão EM4-101-TX1, pois devido a alta impedância de entrada desses módulos, poderia induzir ruídos nas leituras dos sensores Pt 100. 
- A questão da assistência e suporte técnico, particularmente do fabricante do CLP. Em várias oportunidades ocorreu demora nas respostas às dúvidas apresentadas, bem como falta de profundidade e de esclarecimento pleno das mesmas. 
CAPÍTULO 5

\section{CONSIDERAÇÕES FINAIS}


Este capítulo é reservado para o relato das conclusões e contribuições do trabalho, propostas de possíveis melhorias e perspectivas no desenvolvimento do Agrilogic.

\section{CONSIDERAÇÕES FINAIS}

\subsubsection{Conclusões}

Do ponto de vista técnico, a utilização de CLP para a realização de controle climático de casas de vegetação é uma opção atraente, pois permite o controle das variáveis climáticas, e oferece suporte a vários tipos de sensores e atuadores de mercado. A expansão pode ser feita com módulos específicos para entradas e saídas digitais e analógicas, o que proporciona uma boa modularidade ao sistema.

A programação pelo usuário, entretanto, nem sempre é trivial, como no caso do sistema utilizado que não dispõe de uma IHM local. Para compensar esse ponto estão disponíveis formas de comunicação com sistemas supervisórios, SCADA, executadas em computadores pessoais, que permitem desenvolver interfaces amigáveis que representam metáforas gráficas do processo e do sistema. A utilização de comunicação via modem com esse computador de supervisão possibilita que esse nível hierárquico superior esteja localizado remotamente ao processo, o que resulta numa ferramenta de gerenciamento bastante poderosa e conveniente para o agricultor.

A tarefa de integração de sistemas baseados em CLP mostrou-se não tão trivial como se pode supor a princípio, uma vez que demanda a posse e o domínio técnico de diferentes ferramentas de programação proprietárias, tanto do CLP como do Supervisório. A isso se soma a questão da dificuldade de migração de uma marca de PLC para outra, em função do caráter proprietário das soluções. A própria tarefa de instalação, integração do hardware com seus sensores e a comunicação via linha telefônica apresentam diversos desafios, como os referentes à fonte de energia, ao ruído nos sinais dos sensores analógicos, a falha de comunicação e a própria localização de sensores. 
As dificuldades encontradas num ambiente operacional mais controlado como as instalações da USP fazem antever possíveis obstáculos a serem transpostos em ambiente rural, como os mencionados por pessoas ligadas ao meio, conforme puderam ser coletados em entrevistas realizadas ao longo deste trabalho. A elas pode-se adicionar a precária assistência técnica e ao precário apoio obtido do fabricante do CLP.

O custo do CLP ainda é um fator limitante para a sua utilização embora venha diminuindo ao longo do tempo. O custo aproximado do CLP utilizado é de R\$ 3.000,00 sem levar em conta toda infra-estrutura necessária para seu funcionamento, por exemplo, as chaves, a fonte de alimentação, as réguas de distribuição, o modem e o armário. Apenas para referência, durante o desenvolvimento do presente trabalho ocorreu um defeito no módulo analógico de leitura dos sensores Pt 100, o orçamento para conserto apresentado pelo fabricante foi de $\mathrm{R} \$ 400,00$. Adicionam-se aos custos acima a licença de uso do software SCADA e o computador pessoal. Esse custo pode ser considerado elevado para determinados usuários, embora dê flexibilidade no controle climático da casa de vegetação.

Todavia, como um ambiente para estudos esta mostrou-se uma opção atraente, não só pelo fato de que foram utilizados recursos já existentes, portanto sem custo de aquisição para este projeto, mas principalmente pela flexibilidade que permitirá em experimentos futuros, em termos de expansão do hardware e de programação do SCADA.

\subsubsection{Contribuições}

Uma das contribuições do presente trabalho é a disponibilidade de um sistema voltado para experimentação de automação de controle climático de casas de vegetação.

Este é o primeiro trabalho na linha de ambiente protegido do Laboratório de Automação Agrícola que resulta numa aplicação prática. Sua continuidade motivará novos temas de iniciação científica, mestrado e até mesmo doutorado. Devido a sua abrangência, os trabalhos poderão se desenvolver nas mais diversas áreas do controle 
de processos: os sensores, os atuadores, os controladores, os algoritmos e comunicação de dados, entre outros. O presente trabalho motivou a realização de um plano de estágio supervisionado ${ }^{2}$ na EPUSP.

Durante o desenvolvimento do Agrilogic foram realizados vários contatos com fornecedores nacionais e internacionais de equipamentos para automação e com fornecedores de casas de vegetação, abrindo um canal importante para o intercâmbio de informações sobre tecnologias envolvidas em cultivo protegido.

Resultou ainda na criação de um Grupo de estudos de Ambiente Protegido - GAP, que serve de núcleo agregador para os pesquisadores envolvidos nesse tema. Utilizando uma ferramenta de trabalho colaborativo via Intranet, desenvolvida no $\mathrm{LAA}^{3}$, são organizadas as atividades e são disponibilizadas informações geradas internamente, além de referências para outros documentos. Através da página do Grupo de estudos de Ambiente Protegido - GAP pode-se ter acesso a essa base de dados (http://laa.pcs.br/ gap).

\subsubsection{Possíveis melhorias}

Entre as possíveis melhorias destacam-se:

- Aumento da confiabilidade do sistema através do desenvolvimento de rotinas no controlador remoto no intuito de detectar a ocorrência eventual de perda do programa pelo controlador local.

- Evolução da versão do controlador remoto para padrão WEB, possibilitando a divulgação dos dados e informações colhidas na casa de vegetação pela Internet, para toda a comunidade, de maneira automática.

- Instalação de inversores de freqüência nos ventiladores, possibilitando o controle mais fino das condições climáticas da casa de vegetação.

\footnotetext{
${ }^{2}$ PEDRO, G. M. Sistema de Controle de Ambientes. Estágio supervisionado do curso de Engenharia Elétrica, ênfase Controle. Escola Politécnica da Universidade de São Paulo, 2003.1

${ }^{3}$ Desenvolvida por Cartolano Junior, E.A.
} 
- Elaboração de algoritmos de extração da informação do período de utilização dos equipamentos permitindo o planejamento de manutenção preventiva.

- Elaboração de um algoritmo de controle de fotoperíodo.

- Pesquisa e instalação de sensores adicionais, como por exemplo, de velocidade e de direção do vento, de luminosidade e de concentração de gás carbônico, entre outros.

\subsubsection{Perspectivas}

Além das contribuições e melhorias já relacionadas, este trabalho permitiu identificar outras possibilidades, demandas de novos trabalhos e novos caminhos de pesquisa. Devido ao caráter interdisciplinar da área de estudo do cultivo protegido, pode-se dividir as perspectivas em duas frentes:

- Trabalhos que podem ser explorados pelo IB-USP.

- Utilização do Agrilogic para controle das variáveis ambientais da casa de vegetação para o desenvolvimento e manutenção de plantas.

- Elaboração de novos estudos para o desenvolvimento e manutenção de plantas em função das informações climáticas disponíveis e algoritmos de controle do clima da casa de vegetação disponibilizados pelo Agrilogic.

- Acompanhamento de forma remota do ambiente de desenvolvimento das plantas, tendo acesso a histórico do clima para efeito de estudos e também a possibilidade de configuração das condições desejáveis.

- Trabalhos que podem ser explorados pelo LAA

- Levantamento das características dinâmicas da casa de vegetação, no intuito de se criar um modelo matemático que represente as influências dos atuadores nas características climáticas, possibilitando 
dessa forma avaliar o nível de controle do presente sistema e propor novas soluções.

○ Desenvolvimento de algoritmos de controle não convencionais, por exemplo, através da utilização de lógica fuzzy, de redes neurais, levando em consideração não apenas as condições climáticas mais também as questões referentes ao consumo de energia, de água e de nutrientes, entre outras.

○ Exploração da tecnologia de transmissores e receptores sem fio (Wireless) de baixa potência, com alcance limitado, como por exemplo o "Bluetooth", para a monitoração dos sensores e ativação dos atuadores, eliminando a necessidade de cabeamento, a necessidade da determinação prévia e fixa dos pontos de instalação e possíveis fontes de ruídos eletromagnéticos induzidos nos cabos.

- Instalação de um sistema de controle climático baseado em dispositivos em rede LON (Local Operating Network) para efeitos de estudos comparativos das duas tecnologias. Nesse sentido o Agrilogic vem auxiliar no trabalho, servindo como referência. 
REFERÊNCIAS 


\section{REFERÊNCIAS}

AGRINTHER (a). Estufa modelo “AGRI VENLO”. Disponível em: $<$ http://www.agrinther.com.br/agrinvelo.htm>. Acesso em: 05 de mai. 2003.

AGRINTHER (b). Sistema de Ventilação. Disponível em: $<\mathrm{http}: / /$ www.agrinther.com.br/r_ventilacao.htm>. Acesso em: 27 de jan. 2003.

AGRINTHER (c). Sistema de Resfriamento Evaporativo. Disponível em: $<$ http://www.agrinther.com.br/r_resfriamento.htm>. Acesso em: 27 de jan. 2003.

AGRINTHER (d). Sistema de Escurecimento. Disponível em: $<$ http://www.agrinther.com.br/r_sombreamento.htm>. Acesso em: 27 de jan. 2003.

ALBRECHT, W. Hardware and Engineering PS4-201-MM1. 4.ed. Bonn: Moeller GmbH, 1999. (AWB 27-1184 GB).

ARNDT, K.; HERRMANN, J.; KASTNER, E. Language Elements for PS 4-150/200/-300 and PS 416 - Sucosoft S 40 - Programming Software. 6.ed. Bonn: Moeller GmbH, 2000. (AWB 27-1306 GB).

AUTOGROW Systems Ltd. Greenhouse Controllers. Disponível em: $<$ http://www.hydro.co.nz/1_greenhouse_com/greenhouse.html $>$. Acesso em: 14 de fev. 2002.

BLOM, T.J. The Science of Growing - Air Temperature or Plant Temperature. Disponível em: $\quad<$ http://www.priva.ca/newsletter/news-science-airtemp.html $>$. Acesso em: 25 de mar. 2002.

BRADLEY, D. A. et al. Mechatronics: Electronics in products and processes. ed. Cambridge: Chapman and Hall, 1991. 
CEPLA (a). La plasticultura española. Cifras y datos. Disponível em: $<$ http://www.cepla.com/pp06.html>. Acesso em: 14 de out. 2002.

CEPLA (b). Propiedades Radiométricas. Disponível em: $<$ http://www.cepla.com/pp05.html>. Acesso em: 19 de abr. 2002.

DELTA OHM Srl. LP PYRA 02 - LP PYRA 03 - LP PYRA 12 Piranometros. Disponível em: < http://www.deltaohm.com/pyra.pdf>. Acesso em: 05 de mar. 2003.

DIELMANN, A.; HERRMANN J.; STAMMERJOHANN, P. (a) Training Guide Sucosoft S 40 - Programming Software.3.ed. Bonn: Moeller GmbH, 1999. (AWB 27-1307 GB).

DIELMANN, A.; HERRMANN J.; STAMMERJOHANN, P. (b) User Interface Sucosoft S 40 - Programming Software.4.ed. Bonn, Moeller GmbH, 1999. AWB 27-1305 GB.

ELIPSE. Elipse Windows Sistema de Supervisão e Controle - Manual do usuário. Manual técnico do fabricante Elipse Software Ltda, 1999.

ENVIRONDATA (a). Wind Speed - Anemometer. Disponível em: $<$ http://www.environdata.com.au/wind_speed.htm>. Acesso em: 18 de fev. 2003.

ENVIRONDATA (b). Wind Direction Sensor. Disponível em: $<\mathrm{http}$ ://www.environdata.com.au/wind_direction.htm>. Acesso em: 18 de fev. 2003.

ENVIRONDATA (c). Tipping Bucket Raingauge - RG12 Series. Disponível em: $<$ http://www.environdata.com.au/raingauge.pdf $>$. Acesso em: 18 de fev. 2003.

GROßPIETSCH, K. Hardware and Engineering EM 4-101-TX 1: Temperature Sensor Module. Bonn: Moeller GmbH, 1996. (AWB 27-1273-GB).

HANAN, J.J. Greenhouses: advanced technology for protected horticulture. Florida: CRC Press LLC, 1998.

HIDROGOOD Hidroponia Moderna. Estufas Agrícolas. Disponível em: $<$ http://www.hidrogood.com.br/11h/pag/brz/estufas.html $>$. Acesso em: 05 de mar. 2003. 
HONEYWELL. Humidity Sensors - HIH 3610 Series. Disponível em: $<$ http://content.honeywell.com/sensing/prodinfo/humiditymoiusture/009012_2.pdf $>$. Acesso em: 05 de mar. 2003.

INDUSUKI Plasticultura. EXAUSTOR EV. Disponível em: $<$ http://www.indusuki.com.br/exaustor.htm>. Acesso em: 05 de mar. 2003.

INFOAGRO (a). Control Climático en Invernaderos. Disponível em: $<$ http://www.infoagro.com/industria_auxiliar/control_climatico.asp $>$.

Acesso em: 06 de mai. 2002.

INFOAGRO (b). Ventilación en Cultivos Intensivos. Disponível em: $<$ http://www.infoagro.com/industria_auxiliar/ventilacion_cultivos_intensivos.htm $>$. Acesso em: 06 de mai. 2002.

ITE. Fog System. Disponível em: $<$ http://www.encis.net/ite/htm>. Acesso em: 02 de abr. de 2002.

KEMPENICH, G. Instrumentação e Contrôle de Processos - Parte II. São Caetano do Sul: Escola de Engenharia Mauá, 1985. (Apostila).

LORENZO, P. El manejo de clima en invernadero para la producción de hortalizas. Centro de Investigación Agraria (CIFA), Almeria. 2001.

MATHEWS, D. Choosing and Using a Temperature Sensor. Phoenix Contact, Inc. Sensor Magazine, v.17, n.1, January 2000. Disponível em: $<$ http://www.sensorsmag.com/articles/0100/54/index.htm>. Acesso em: 05 de mar. 2003.

MICRO GROW Greenhouse Systems, Inc. Growmaster Procom. Disponível em: $<$ http://www.microgrow.com/growmaster-procom.html $>$. Acesso em: 09 de nov. 2002.

MORAES, C.C.; CASTRUCCI, P. L. Engenharia de Automação Industrial. Rio de Janeiro: LTC - Livros Técnicos e Científicos Editora, 2001.

MORAIS, R. et al. Microcontrollers Developments and its Application to Agriculture: A Greenhouse Control System. In: INTERNATIONAL CONFERENCE ON COMPUTERS IN AGRICULTURE, 17., Orlando, 1998. Proceedings. Orlando: ASAE, 1998. (CD-ROM). 
NELSON, P.V. Greenhouse Operation and Management. 4.ed. New Jersey: Prentice Hall, 1991.

OLIVEIRA, C. R. et al. Cultivo em Ambiente Protegido. Boletim técnico da CATI, Campinas, n.232, 1997.

P. L. LIGHT Systems. Horticulture. Disponível em: $<$ http://www.pllight/horticulture/news/>. Acesso em: 05 de mar. 2003.

PRIVA (a). CO2 Generators / Heaters. Disponível em: $<$ http://www.priva.ca/co2generator.htm>. Acesso em: 28 de jan. 2003.

PRIVA (b). Measuring Sunlight. Disponível em: $<$ http://www.priva.ca/newsletter/news-what\%20is\%20sunlight.html $>$. Acesso em: 25 de mar. 2002.

QCOM. Q-COM PRODUCTS. Disponível em: $<$ http://www.qcom-controls.com/products.htm>. Acesso em: 04 de abr. 2003.

REIS, N. V. B; MAKISHIMA, N. Uma visão geral sobre as oportunidades com os cultivos protegidos diante das condições climáticas do Brasil. Emprapa Hortaliças, Brasília, DF, n. 52/53, p. 13-17, dez.2001/2002.

RMS. Monitoring Relative Humidity. Disponível em: $<$ http://www.measure.com/sensors/sensor-humidity.html $>$. Acesso em $13 \mathrm{de}$ fev. 2002.

RODRÍGUEZ, F.; BERENGUEL M. Sistemas de control climático de invernaderos. Universidad de Almería. Espanha. Disponível em: $<$ http://www.cepla.com/euroagro/7/7.html $>$. Acesso em: 19 de abr. 2002.

ROERSCH, P. Hardware und Projektierund EM4-101-DD2 EM4-111-DR2 EM4-101-AA2 EM4-201-DX2 Erweiterungsmodul mit Suconet-K1/K Schnittstelle. 3.ed. Bonn: Moeller GmbH, 2001. (AWB27-1257-D).

SFASU. History of Greenhouse Development. Disponível em: $<$ http://www.sfasu.edu/ag/horticulture/hrt321/ghhistory1.html $>$. Acesso em: 24 de out. 2002. 
SINCLAIR, I. R. Sensors and Transducers: A guide for technicians. 2.ed. Oxford: Butterworth-Heinemann, 1995.

SIMPSON, C. D. PROGRAMMABLE LOGIC CONTROLLERS. New Jersey: Regent/Prentice Hall, 1994.

TECWAY. Sensor de Temperatura. Disponível em: $<$ http://www.tecwaybr.com/ntc-kc.htm>. Acesso em: 19 de fev. 2003.

THAYER, R. H. Carbon Dioxide Enrichment Methods. Eco Enterprises. 2003. Disponível em: < http://www.hydrofarm.com/content/articles/co2.html $>$. Acesso em: 27 de jan. 2003.

TRIETLEY, H. L. Transducers in Mechanical and Electronic Design. New York: Dekker, 1986.

TROPICAL Estufas Agrícolas Ltda (a). Estufas para Diversos Fins. Disponível em: $<$ http://www.tropicalestufas.com.br/outras/p2.htm>. Acesso em: 27 de jan. 2003.

TROPICAL Estufas Agrícolas Ltda (b). Estufas com Lanternim. Disponível em: $<$ http://www.tropicalestufas.com.br/lanternin/p2.htm>. Acesso em: 27 de jan. 2003.

VAN DER HOEVEN Ind. Com. Estufas Agrícolas Ltda (a). Modelos de Estufas Poly House. Disponível em: $<$ http://www.vanderhoeven.com.br/modelos/house.htm>. Acesso em: 05 de mar. 2003.

VAN DER HOEVEN Ind. Com. Estufas Agrícolas Ltda (b). Modelos de Estufas Viveiro. Disponível em: <http://www.vanderhoeven.com.br/modelos/vive.htm>. Acesso em: 05 de mar. 2003.

VECCHIA, P. T. D; KOCH, P. S. História e perspectivas da produção de hortaliças em ambiente protegido no Brasil. Informe Agropecuário, Belo Horizonte, v.20, n.200/201, p.5-10, set./dez. 1999. 
APÊNDICE 
Este apêndice ilustra os detalhes da interligação elétrica do armário de CLP e do armário de comando original da casa de vegetação do IBUSP.

\begin{abstract}
APÊNDICE
Objetiva-se aqui a dar maiores detalhes da interligação do armário de CLP com o armário de comandos. Durante todo o desenvolvimento do presente trabalho existiu a preocupação em se preservar a possibilidade de se operar a casa de vegetação utilizando o circuito de controle original baseado em lógica à relé. Com esse intuito instalou-se uma chave geral junto ao armário de comandos, a qual permite ligar ou desligar o armário de CLP. Esta chave possibilita selecionar o sistema de controle. Quando a chave estiver ligada o controle é realizado pelo Agrilogic e quando a chave estiver desligada o controle é realizado pelo circuito original da casa de vegetação. A única restrição é que para o correto funcionamento do Agrilogic, as chaves de controle dos equipamentos no armário de comandos devem ser posicionadas na posição "desligada".

A interligação pode ser visualizada através do esquema elétrico da casa de vegetação do IB-USP, figuras 1 e 2 , e do diagrama principal (força motriz), figuras 3 e 4 . No intuito de facilitar a visualização das alterações elétricas realizadas, os novos circuitos foram desenhados em vermelho e adotou-se a nomenclatura:
\end{abstract}

- $\mathrm{SD}_{\mathrm{X}}$, utilizada para referenciar os sensores digitais e estão representados na figura 4. Onde "x" é um número de identificação e varia de 1 até 16 , devido a existência de oito entradas digitais no CLP. Para cada entrada é necessário se utilizar um contato normalmente fechado do contator de controle dos equipamentos. Os sensores de porta (SD13 e SD14) e de janelas (SD15 e SD16) não estão representados nas figuras.

- $\mathrm{AD}_{\mathrm{X}}$, utilizada para referenciar os atuadores controlados digitalmente e estão representados nas figuras1 e 2. Onde “x” é um número de identificação e 
varia de 1 até 12 , devido a existência de seis saídas digitais no CLP. Cada saída controla um relé que possui dois contatos do tipo normalmente aberto.

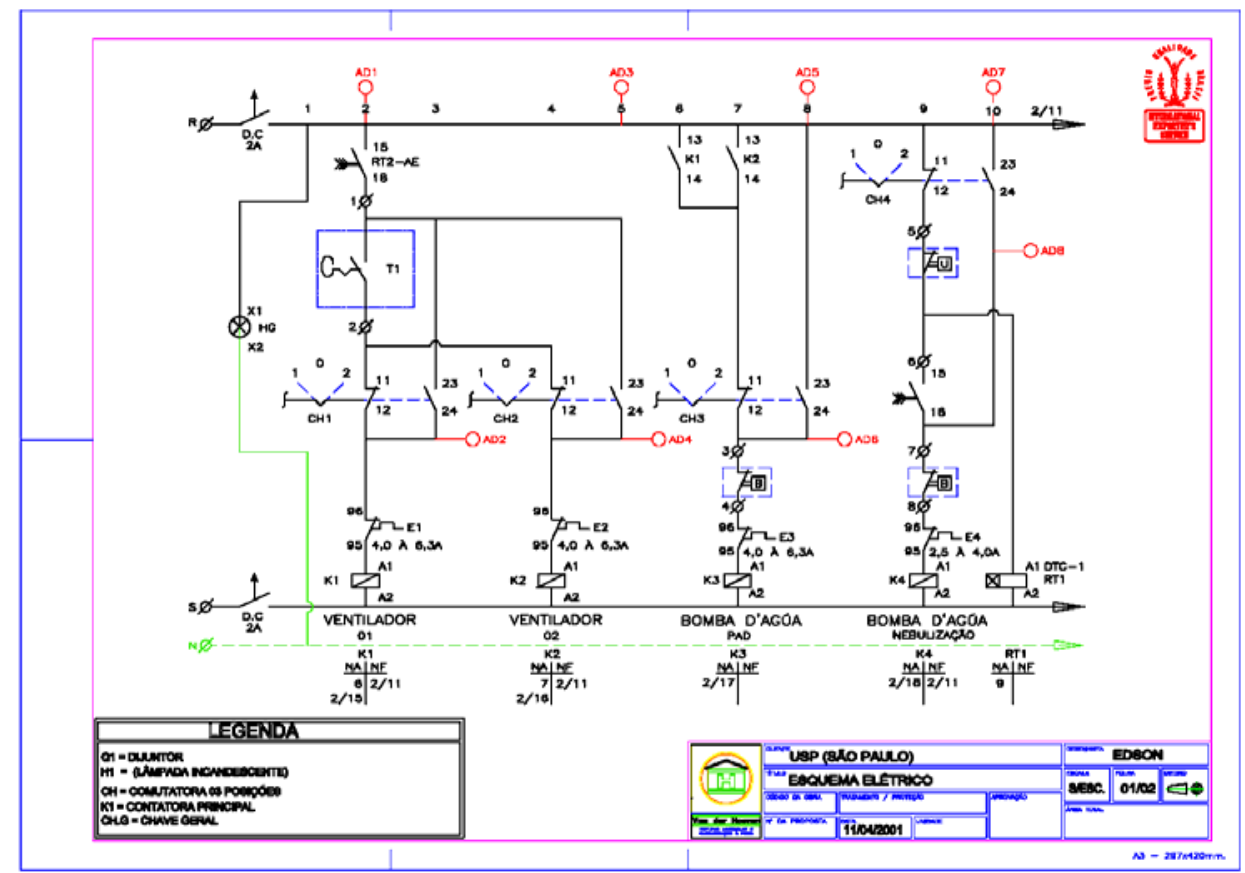

Fonte: Van der Hoeven (2003)

Figura 1 - Esquema elétrico da casa de vegetação do IB-USP folha 01/02 


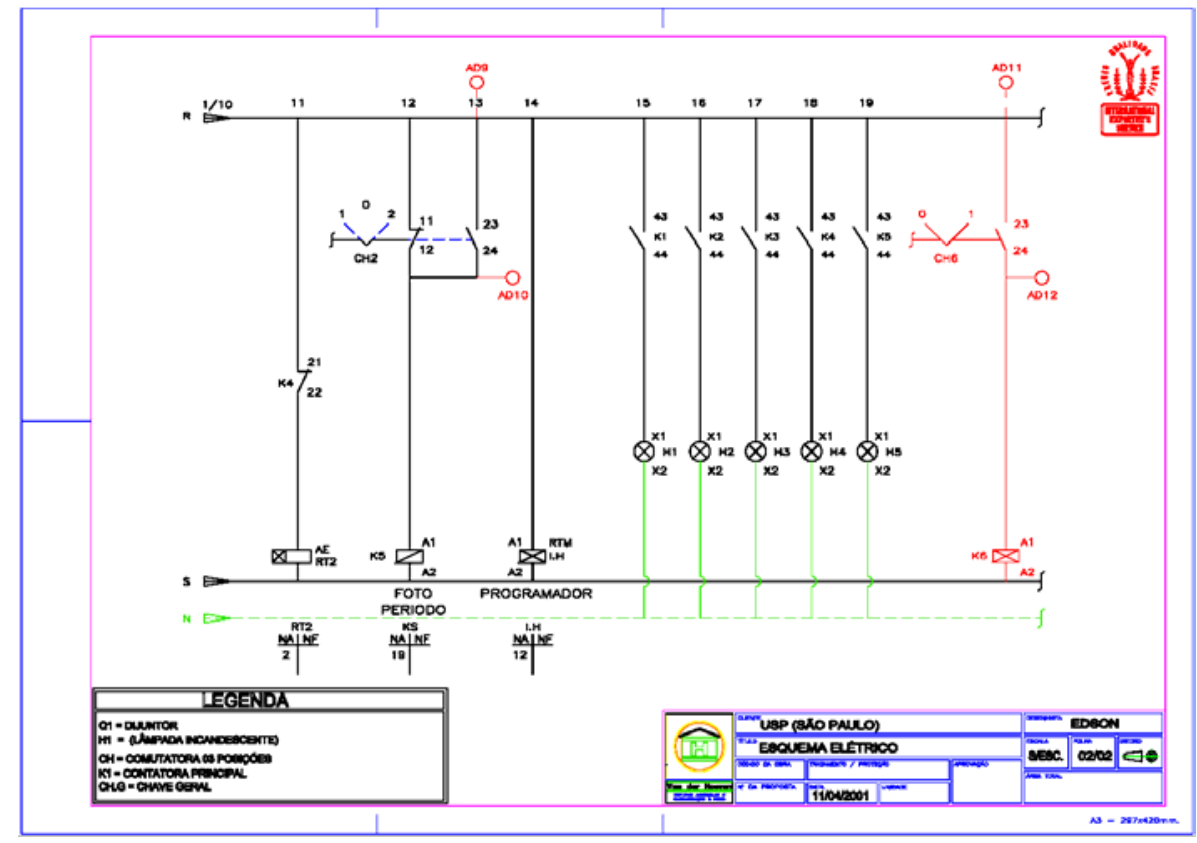

Fonte: Van der Hoeven (2003)

Figura 2 - Esquema elétrico da casa de vegetação do IB-USP folha 02/02

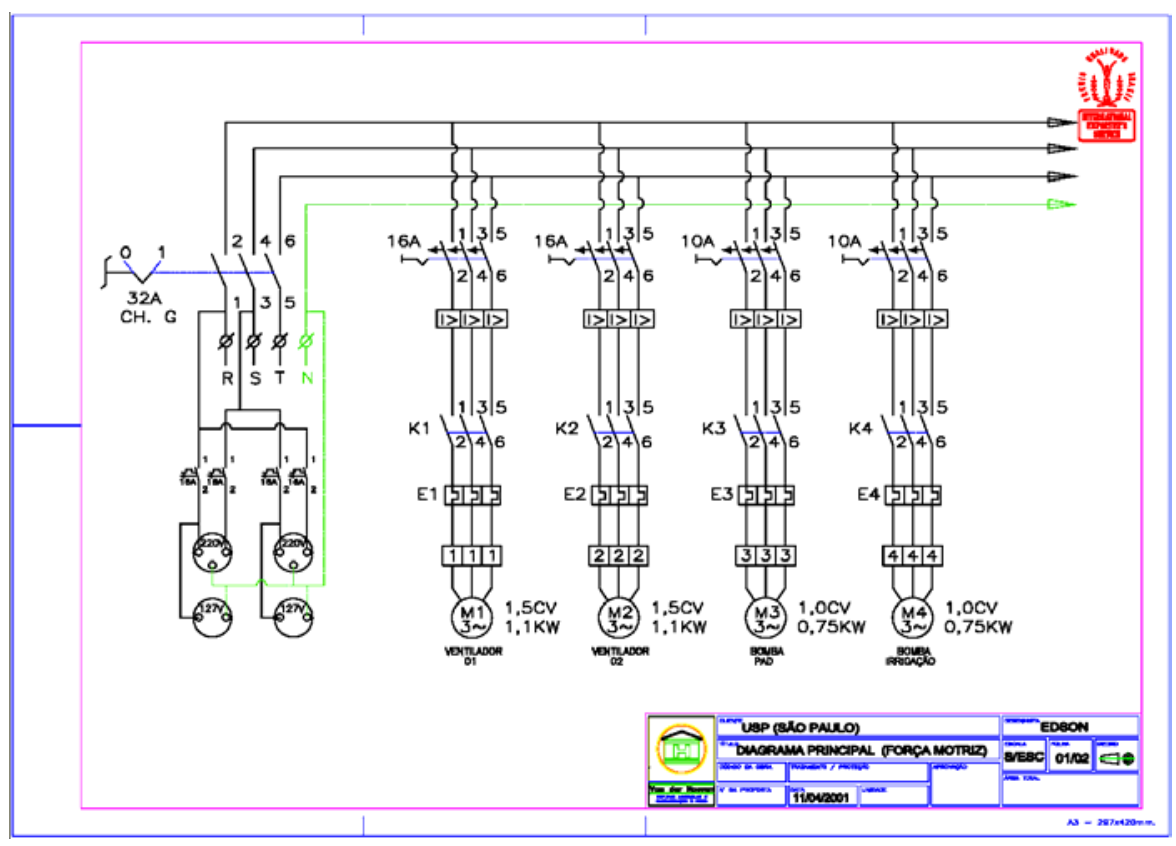

Fonte: Van der Hoeven (2003)

Figura 3 - Diagrama principal (força motriz) da casa de vegetação do IB-USP folha $01 / 02$ 


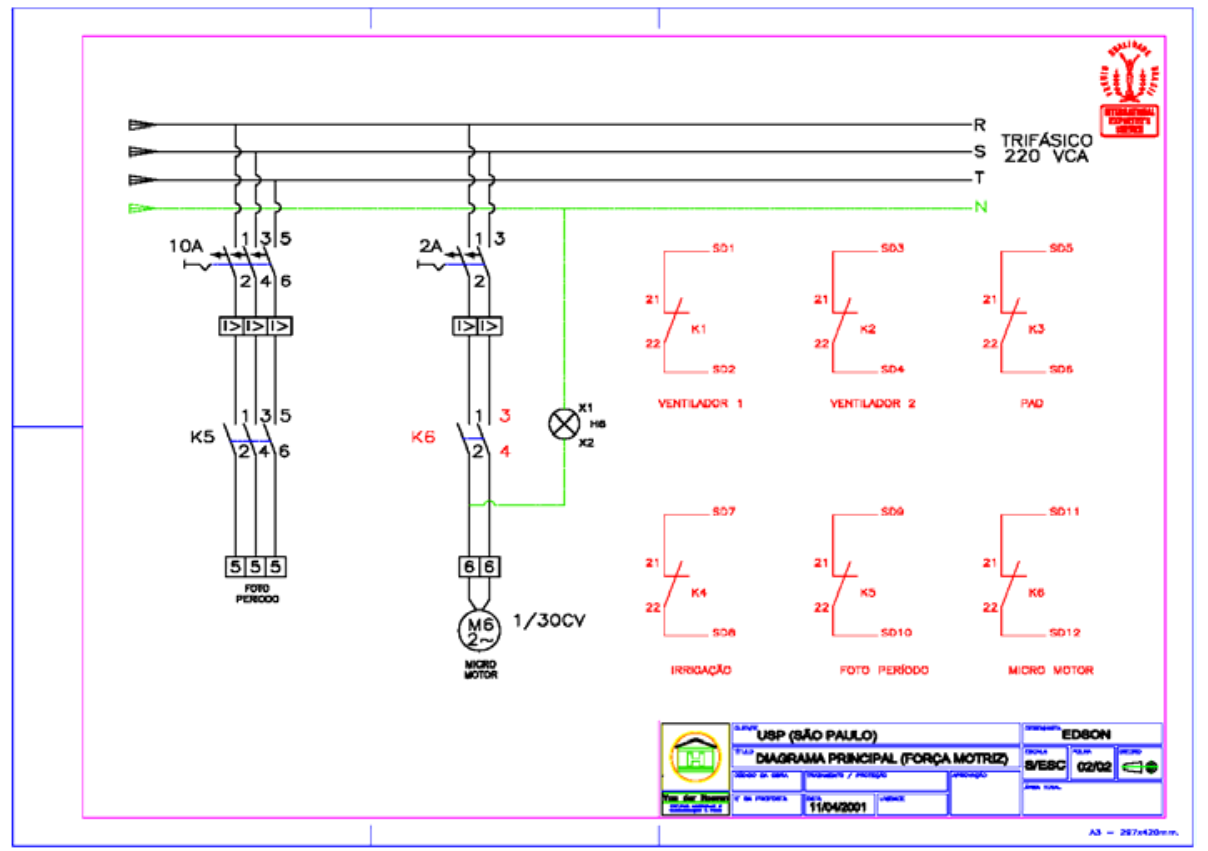

Fonte: Van der Hoeven (2003)

Figura 4 - Diagrama principal (força motriz) da casa de vegetação do IB-USP folha $02 / 02$

Devido à necessidade de se condicionar os sinais fornecidos pelos sensores digitais nos padrões especificados pelo fabricante do CLP, foi necessária a utilização do circuito elétrico da figura 5 .

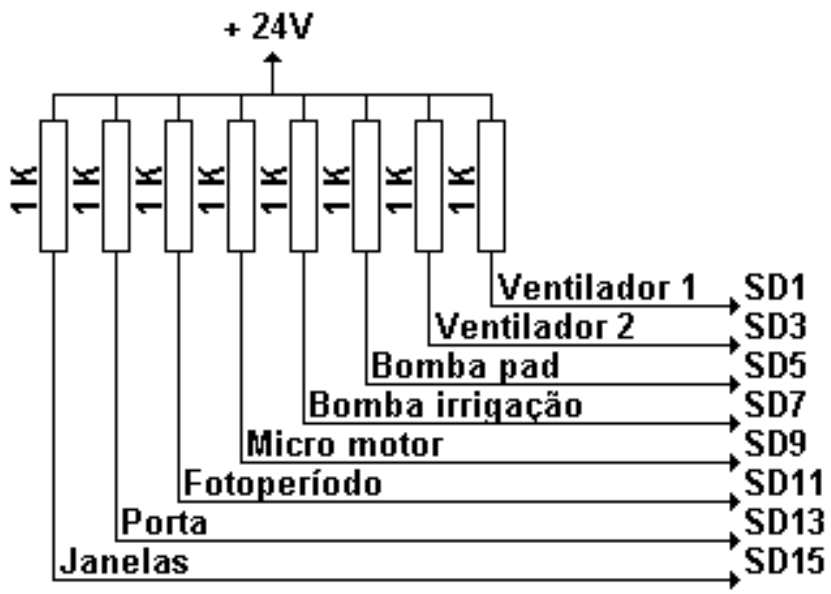

Figura 5 - Circuito resistivo para entrada digital 
A tabela 1 resume a interligação dos sensores digitais, relacionando o nome do sinal com os pontos de ligações no armário de CLP e no armário de comandos, bem como o equipamento monitorado e os números das figuras em que o sinal é referenciado.

Tabela 1 - Interligação dos sensores digitais

\begin{tabular}{|l|l|l|l|r|}
\hline Sinal & \multicolumn{1}{|c|}{ Armário de CLP } & \multicolumn{1}{|c|}{ Armário de comandos } & \multicolumn{1}{|c|}{ Equipamento } & Fig \\
\hline SD1 & CR1 - Circuito resistivo 1 & Ponto 21 do contator K1 & Ventilador 1 & 4,5 \\
\hline SD2 & .0 Entrada digital do CLP & Ponto 22 do contator K1 & Ventilador 1 & 4,5 \\
\hline SD3 & CR2 - Circuito resistivo 2 & Ponto 21 do contator K2 & Ventilador 2 & 4,5 \\
\hline SD4 & 1 Entrada digital do CLP & Ponto 22 do contator K2 & Ventilador 2 & 4,5 \\
\hline SD5 & CR3 - Circuito resistivo 3 & Ponto 21 do contator K3 & Bomba d'água pad & 4,5 \\
\hline SD6 & .2 Entrada digital do CLP & Ponto 22 do contator K3 & Bomba d'água pad & 4,5 \\
\hline SD7 & CR4 - Circuito resistivo 4 & Ponto 21 do contator K4 & Bomba d'água irrigação & 4,5 \\
\hline SD8 & 3 Entrada digital do CLP & Ponto 22 do contator K4 & Bomba d'água irrigação & 4,5 \\
\hline SD9 & CR5 - Circuito resistivo 5 & Ponto 21 do contator K5 & Fotoperíodo & 4,5 \\
\hline SD10 & 4 Entrada digital do CLP & Ponto 22 do contator K5 & Fotoperíodo & 4,5 \\
\hline SD11 & CR6 - Circuito resistivo 6 & Ponto 21 do contator K6 & Micro motor & 4,5 \\
\hline SD12 & .5 Entrada digital do CLP & Ponto 22 do contator K6 & Micro motor & 4,5 \\
\hline SD13 & CR7 - Circuito resistivo 7 & - & Porta & 5 \\
\hline SD14 & 6 Entrada digital do CLP & - & Porta & 5 \\
\hline SD15 & CR8 - Circuito resistivo 8 & - & Janelas & 5 \\
\hline SD16 & .7 Entrada digital do CLP & - & Janelas & 5 \\
\hline
\end{tabular}

Em função do sinal de saída digital do CLP não ser adequado para a comutação direta dos equipamentos envolvidos no processo foi necessário a utilização de seis circuitos idênticos ao da figura 6. Nesta figura a entrada (.X), corresponde às seis saídas digitais disponíveis no CLP PS4-201-MM1, desde (.0 até .5). As saídas do circuito ADY e ADZ são utilizadas para a comutação dos equipamentos. Por exemplo: a saída .0 do CLP comanda a abertura ou fechamento dos contatos AD1 e $\mathrm{AD} 2$, os quais são utilizados para desligar ou ligar o ventilador 1. 


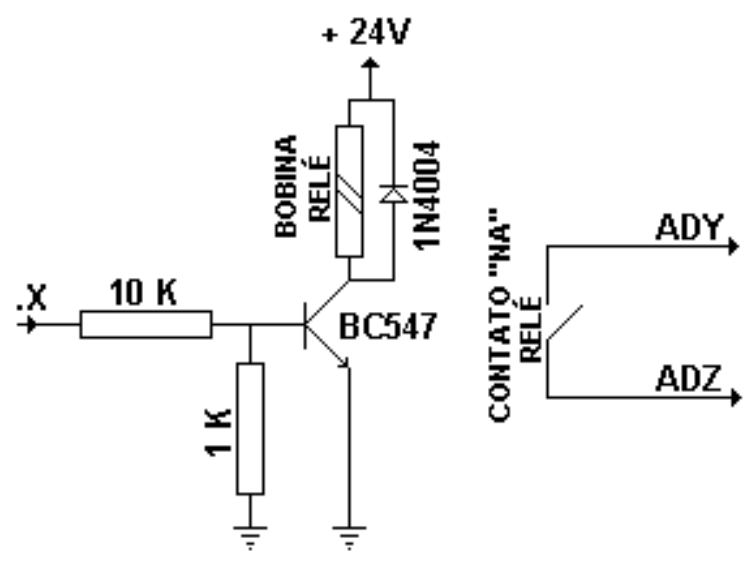

Figura 6 - Circuito de relés acionadores

A tabela 2 resume a interligação dos atuadores controlados digitalmente, relacionando o nome do sinal com os pontos de ligações no armário de CLP e no armário de comandos, bem como o equipamento envolvido e os números das figuras em que o sinal é referenciado.

Tabela 2 - Interligação dos atuadores controlados digitalmente

\begin{tabular}{|l|c|l|l|l|}
\hline Sinal & Armário de CLP & \multicolumn{1}{|c|}{ Armário de comandos } & \multicolumn{1}{|c|}{ Equipamento } & Fig \\
\hline AD1 & NA1 Relé atuador 1 & Fase R da alimentação AC & Ventilador 1 & 1,6 \\
\hline AD2 & NA2 Relé atuador 1 & Ponto 12 da chave CH1 & Ventilador 1 & 1,6 \\
\hline AD3 & NA1 Relé atuador 2 & Fase R da alimentação AC & Ventilador 2 & 1,6 \\
\hline AD4 & NA2 Relé atuador 2 & Ponto 12 da chave CH2 & Ventilador 2 & 1,6 \\
\hline AD5 & NA1 Relé atuador 3 & Fase R da alimentação AC & Bomba d'água pad & 1,6 \\
\hline AD6 & NA2 Relé atuador 3 & Ponto 12 da chave CH3 & Bomba d'água pad & 1,6 \\
\hline AD7 & NA1 Relé atuador 4 & Fase R da alimentação AC & Bomba d'água irrigação & 1,6 \\
\hline AD8 & NA2 Relé atuador 4 & Ponto 24 da chave CH4 & Bomba d'água irrigação & 1,6 \\
\hline AD9 & NA1 Relé atuador 5 & Fase R da alimentação AC & Fotoperíodo & 2,6 \\
\hline AD10 & NA2 Relé atuador 5 & Ponto 12 da chave CH5 & Fotoperíodo & 2,6 \\
\hline AD11 & NA1 Relé atuador 6 & Fase R da alimentação AC & Micro motor & 2,6 \\
\hline AD12 & NA2 Relé atuador 6 & Ponto A1 do relé K6 & Micro motor & 2,6 \\
\hline
\end{tabular}

